Prepared in cooperation with the Missouri Department of Transportation

\title{
Bathymetric Surveys at Highway Bridges Crossing the Missouri River in Kansas City, Missouri, using a Multibeam Echo Sounder, 2010
}

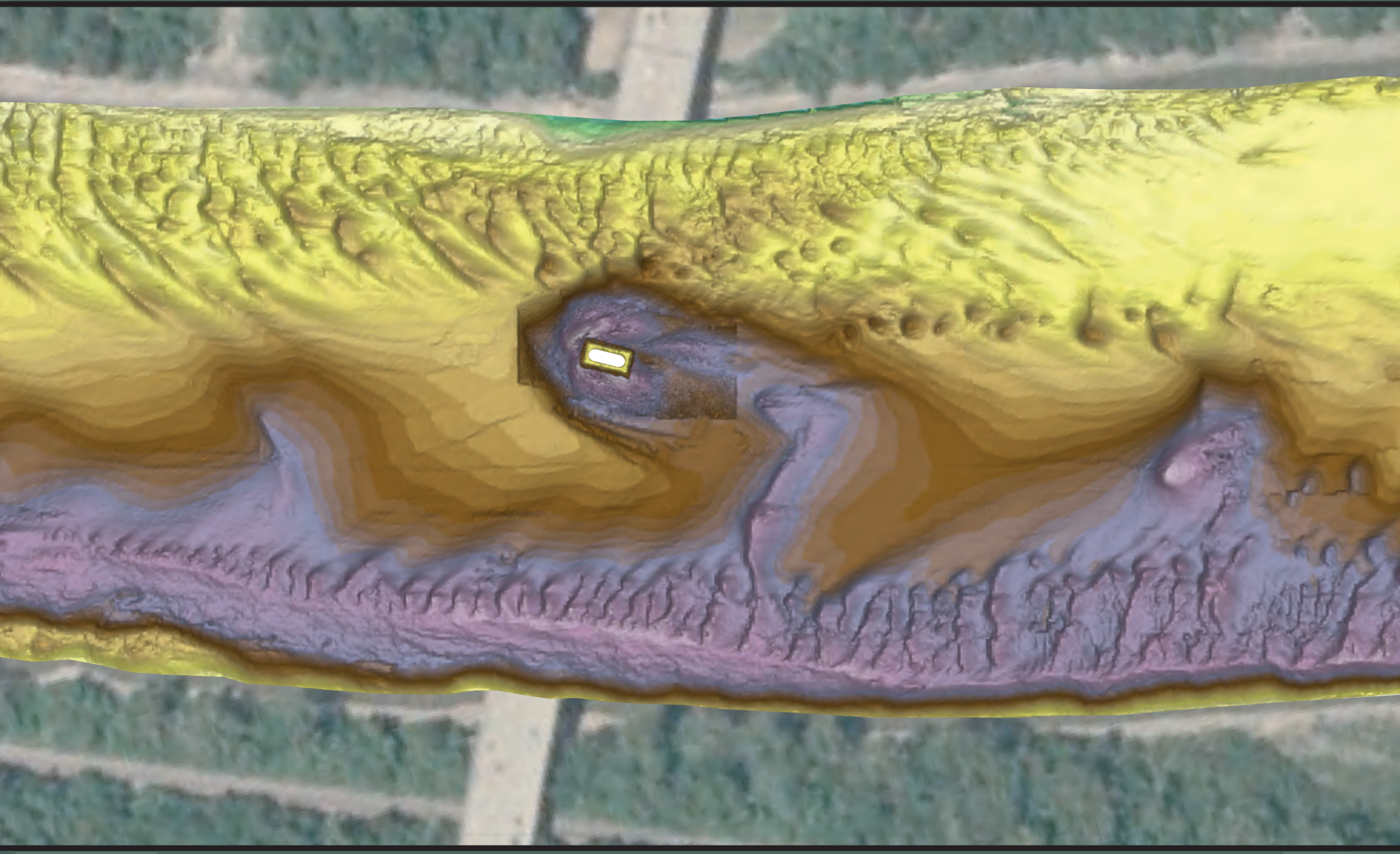

Scientific Investigations Report 2010-5207 
Cover. Bathymetric survey of the Missouri River channel in the vicinity of structure A1800 on Interstate 635 in Kansas City, Missouri. 


\section{Bathymetric Surveys at Highway Bridges Crossing the Missouri River in Kansas City, Missouri, using a Multibeam Echo Sounder, 2010}

By Richard J. Huizinga

Prepared in cooperation with the Missouri Department of Transportation

Scientific Investigations Report 2010-5207 


\title{
U.S. Department of the Interior \\ KEN SALAZAR, Secretary \\ U.S. Geological Survey \\ Marcia K. McNutt, Director
}

\section{U.S. Geological Survey, Reston, Virginia: 2010}

\author{
For more information on the USGS — the Federal source for science about the Earth, its natural and living resources, \\ natural hazards, and the environment, visit http://www.usgs.gov or call 1-888-ASK-USGS \\ For an overview of USGS information products, including maps, imagery, and publications, \\ visit http://www.usgs.gov/pubprod \\ To order this and other USGS information products, visit http://store.usgs.gov
}

Any use of trade, product, or firm names is for descriptive purposes only and does not imply endorsement by the U.S. Government.

Although this report is in the public domain, permission must be secured from the individual copyright owners to reproduce any copyrighted materials contained within this report.

Suggested citation:

Huizinga, R.J., 2010, Bathymetric surveys at highway bridges crossing the Missouri River in Kansas City, Missouri, using a multibeam echo sounder, 2010: U.S. Geological Survey Scientific Investigations Report 2010-5207, 61 p. 


\section{Contents}

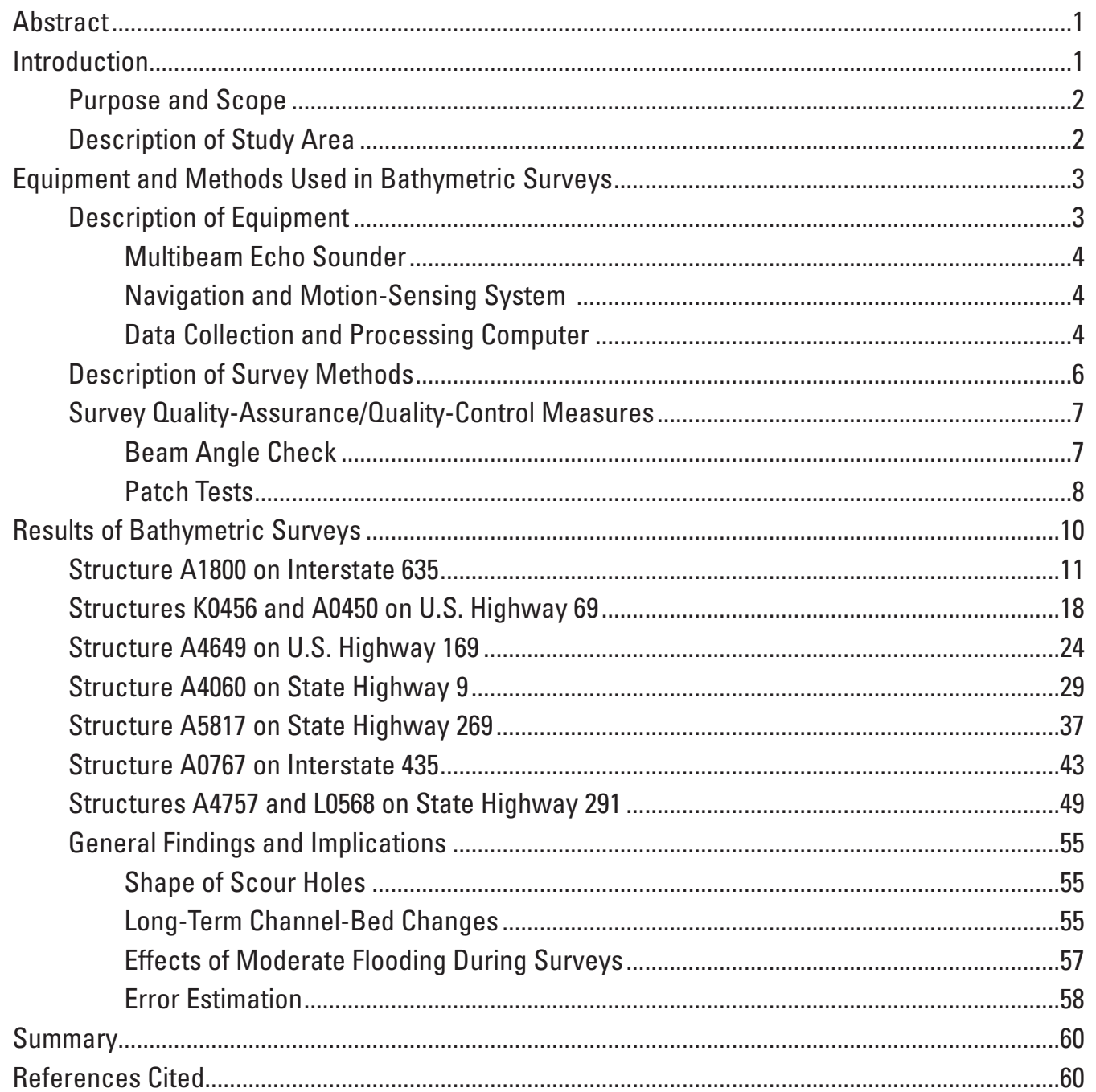




\section{Figures}

1. Map showing location of bridges crossing the Missouri River in the Kansas City, Missouri, area

2. Photographs showing the multibeam echo sounder as viewed $A$, from the bottom, $B$, from the top, and $C$, mounted on the port side of the U.S. Geological Survey boat

3. Diagram showing approximate beam geometry of the multibeam echo sounder $A$, across ship track and $B$, along ship track.....

4. Diagram showing approximate beam geometry of the multibeam echo sounder with a tilted head to obtain soundings $A$, along a river bank or $B$, on the side of a vertical structure

5. Diagram showing method of survey line spacing used to ensure complete coverage of the channel bed and minimize sonic "shadows"

6. Diagram show effects of timing and angular offsets for $A$, latency, $B$, roll, $C$, pitch, and $D$, yaw on data from a multibeam echo sounder.

7. Aerial photograph showing location of the bathymetric survey area on the Missouri River near structure A1800 on Interstate 635 in Kansas City, Missouri.

8. Bathymetric survey of the Missouri River channel in the vicinity of structure A1800 on Interstate 635 in Kansas City, Missouri.

9. Bathymetric survey of the Missouri River channel in the vicinity of the main channel pier of structure A1800 on Interstate 635 in Kansas City, Missouri

10. Diagram showing key features, substructural and superstructural details, and surveyed channel bed of structure A1800 on Interstate 635 over the Missouri River in Kansas City, Missouri

11. Point cloud visualization of the channel bed and left (north) side of the main channel pier of structure A1800 on Interstate 635 over the Missouri River in Kansas City, Missouri

12. Aerial photograph showing location of the bathymetric survey area on the Missouri River near structures K0456 and A0450 on U.S. Highway 69 in Kansas City, Missouri

13. Bathymetric survey of the Missouri River channel in the vicinity of structures K0456 and A0450 on U.S. Highway 69 in Kansas City, Missouri.

14. Bathymetric survey of the Missouri River channel in the vicinity of the main channel piers of structures K0456 and A0450 on U.S. Highway 69 in Kansas City, Missouri.

15. Diagram showing key features, substructural and superstructural details, and surveyed channel bed of structure K0456 on U.S. Highway 69 over the Missouri River in Kansas City, Missouri

16. Diagram showing key features, substructural and superstructural details, and surveyed channel bed of structure A0450 on U.S. Highway 69 over the Missouri River in Kansas City, Missouri

17. Aerial photograph showing location of the bathymetric survey area on the Missouri River near structure A4649 on U.S. Highway 169 in Kansas City, Missouri.....25

18. Bathymetric survey of the Missouri River channel in the vicinity of structure A4649 on U.S. Highway 169 in Kansas City, Missouri

19. Bathymetric survey of the Missouri River channel in the vicinity of the main channel pier of structure A4649 on U.S. Highway 169 in Kansas City, Missouri. 
20. Diagram showing key features, substructural and superstructural details, and surveyed channel bed of structure A4649 on U.S. Highway 169 over the Missouri River in Kansas City, Missouri.

21. Aerial photograph showing location of the bathymetric survey area on the Missouri River near structure A4060 on State Highway 9 in Kansas City, Missouri .......30

22. Bathymetric survey of the Missouri River channel in the vicinity of structure A4060 on State Highway 9 in Kansas City, Missouri

23. Bathymetric survey of the Missouri River channel in the vicinity of the right main channel pier of structure A4060 on State Highway 9 in Kansas City, Missouri

24. Diagram showing key features, substructural and superstructural details, and surveyed channel bed of structure A4060 on State Highway 9 over the Missouri River in Kansas City, Missouri

25. Point cloud visualization of the channel bed and right (south) side of the right main channel pier (pier 6) of structure A4060 on State Highway 9 over the Missouri River in Kansas City, Missouri.

26. Bathymetric survey of the Missouri River channel in the vicinity of the left main channel pier of structure A4060 on State Highway 9 in Kansas City, Missouri

27. Point cloud visualization of the channel bed and right (south) side of the left main channel pier (pier 5) of structure A4060 on State Highway 9 over the Missouri River in Kansas City, Missouri.

28. Aerial photograph showing location of the bathymetric survey area on the Missouri River near structure A5817 on State Highway 269 in Kansas City, Missouri.

29. Bathymetric survey of the Missouri River channel in the vicinity of structure A5817 on State Highway 269 in Kansas City, Missouri.

30. Bathymetric survey of the Missouri River channel in the vicinity of the main channel pier of structure A5817 on State Highway 269 in Kansas City, Missouri

31. Diagram showing key features, substructural and superstructural details, and surveyed channel bed of structure A5817 on State Highway 269 over the Missouri River in Kansas City, Missouri

32. Point cloud visualization of the channel bed and left (north) side of the main channel pier of structure A5817 on State Highway 269 over the Missouri River in Kansas City, Missouri.

33. Aerial photograph showing location of the bathymetric survey area on the Missouri River near structure A0767 on Interstate 435 in Kansas City, Missouri

34. Bathymetric survey of the Missouri River channel in the vicinity of structure A0767 on Interstate 435 in Kansas City, Missouri

35. Bathymetric survey of the Missouri River channel in the vicinity of the main channel pier of structure A0767 on Interstate 435 in Kansas City, Missouri..

36. Diagram showing key features, substructural and superstructural details, and surveyed channel bed of structure A0767 on Interstate 435 over the Missouri River in Kansas City, Missour .

37. Point cloud visualization of the channel bed and left (north) side of the main channel pier of structure A0767 on Interstate 435 over the Missouri River in Kansas City, Missouri.

38. Aerial photograph showing location of the bathymetric survey area on the Missouri River near structures A4757 and L0568 on State Highway 291 in Kansas City, Missouri. 
39. Bathymetric survey of the Missouri River channel in the vicinity of structures A4757 and L0568 on State Highway 291 in Kansas City, Missouri.

40. Bathymetric survey of the Missouri River channel in the vicinity of the main channel piers of structures A4757 and L0568 on State Highway 291 in Kansas City, Missouri.

41. Diagram showing key features, substructural and superstructural details, and surveyed channel bed of structure A4757 on State Highway 291 over the Missouri River in Kansas City, Missouri

42. Diagram showing key features, substructural and superstructural details, and surveyed channel bed of structure L0568 on State Highway 291 over the Missouri River in Kansas City, Missouri

43. Graphs showing longitudinal profiles upstream from piers at the structures surveyed on the Missouri River at Kansas City, Missouri.

44. Scatter plot showing water-surface elevation for a given discharge range with time from measurements made at the streamflow-gaging station on the Missouri River at Kansas City, Missouri

45. Scatter plot showing average channel-bed elevation with time from measurements made at the streamflow-gaging station on the Missouri River at Kansas City, Missouri

46. Aerial photograph showing total propagated error of bathymetric data from the Missouri River channel in the vicinity of structure A1800 on Interstate 635 in Kansas City, Missouri

\section{Tables}

1. Bridges crossing the Missouri River in the Kansas City, Missouri, area, in downstream order

2. Results of a beam angle check from two check lines over a reference surface at Blue Springs Lake, Missouri, on March 18, 2010

3. Results of patch tests performed each day of surveying on the Missouri River in Kansas City, Missouri, and at Blue Springs Lake, Missouri

4. Bridge and survey information and minimum elevations in the channel and scour holes from surveys on the Missouri River in Kansas City, Missouri, from March 15-18, 2010

5. Results at upstream pier faces from surveys on the Missouri River in Kansas City, Missouri, from March 15-18, 2010. 


\section{Conversion Factors}

Inch/Pound to SI

\begin{tabular}{|c|c|c|}
\hline Multiply & By & To obtain \\
\hline \multicolumn{3}{|c|}{ Length } \\
\hline inch (in.) & 2.54 & centimeter $(\mathrm{cm})$ \\
\hline foot $(\mathrm{ft})$ & 0.3048 & meter $(m)$ \\
\hline mile (mi) & 1.609 & kilometer $(\mathrm{km})$ \\
\hline \multicolumn{3}{|c|}{ Flow rate } \\
\hline cubic foot per second $\left(\mathrm{ft}^{3} / \mathrm{s}\right)$ & 0.02832 & cubic meter per second $\left(\mathrm{m}^{3} / \mathrm{s}\right)$ \\
\hline
\end{tabular}

Vertical coordinate information is referenced to the North American Vertical Datum of 1988

(NAVD 88). The difference between NAVD 88 and the National Geodetic Vertical Datum of 1929

(NGVD 29) ranges from 0.26 to 0.28 foot throughout the study area, with an average value of 0.27 foot.

Horizontal coordinate information is referenced to the North American Datum of 1983 (NAD 83).

In this report, the words "left" and "right" generally refer to directions that would be reported by an observer facing downstream. 



\title{
Bathymetric Surveys at Highway Bridges Crossing the Missouri River in Kansas City, Missouri, using a Multibeam Echo Sounder, 2010
}

\author{
By Richard J. Huizinga
}

\section{Abstract}

Bathymetric surveys were conducted by the U.S. Geological Survey, in cooperation with the Missouri Department of Transportation, on the Missouri River in the vicinity of nine bridges at seven highway crossings in Kansas City, Missouri, in March 2010. A multibeam echo sounder mapping system was used to obtain channel-bed elevations for river reaches that ranged from 1,640 to 1,800 feet long and extending from bank to bank in the main channel of the Missouri River. These bathymetric scans will be used by the Missouri Department of Transportation to assess the condition of the bridges for stability and integrity with respect to bridge scour.

Bathymetric data were collected around every pier that was in water, except those at the edge of the water or in extremely shallow water, and one pier that was surrounded by a large debris raft. A scour hole was present at every pier for which bathymetric data could be obtained. The scour hole at a given pier varied in depth relative to the upstream channel bed, depending on the presence and proximity of other piers or structures upstream from the pier in question. The surveyed channel bed at the bottom of the scour hole was between 5 and 50 feet above bedrock.

At bridges with drilled shaft foundations, generally there was exposure of the upstream end of the seal course and the seal course often was undermined to some extent. At one site, the minimum elevation of the scour hole at the main channel pier was about 10 feet below the bottom of the seal course, and the sides of the drilled shafts were evident in a point cloud visualization of the data at that pier. However, drilled shafts generally penetrated 20 feet into bedrock. Undermining of the seal course was evident as a sonic "shadow" in the point cloud visualization of several of the piers.

Large dune features were present in the channel at nearly all of the surveyed sites, as were numerous smaller dunes and many ripples. Several of the sites are on or near bends in the river, resulting in a deep channel thalweg on the outside of the bend at these sites. At structure A5817 on State Highway 269, bedrock exposure was evident in the channel thalweg. The surveyed channel bed at a given site from this study generally was lower than the channel bed obtained during Level II scour assessments in 2002.

At piers with well-defined scour holes, the frontal slopes of the holes were somewhat less than recommended values in the literature, and the shape of the holes appeared to be affected by the movement of dune features into and around the holes. The channel bed at all of the surveyed sites was lower than the channel bed at the time of construction, and an analysis of measurement data from the U.S. Geological Survey continuous streamflow-gaging station on the Missouri River at Kansas City, Missouri (station number 06893000), confirmed a lowering trend of the channel-bed elevations with time at the gaging station.

The size of the scour holes observed at the surveyed sites likely was affected by the moderate flood conditions on the Missouri River at the time of the surveys. The scour holes likely would be substantially smaller during conditions of low flow.

\section{Introduction}

Scour is the removal of channel bed and bank material by flowing water and is the leading cause of bridge failures in the United States (Richardson and Davis, 2001). Scour at a bridge site is the result of long-term geomorphological processes and the local effects caused by elements of the structure in or adjacent to the waterway (Richardson and Davis, 2001; Huizinga and Rydlund, 2004). Because the effects can be severe and dangerous, bridges and other structures over waterways are routinely assessed and inspected for the effects of scour.

The Missouri Department of Transportation (MoDOT) is responsible for most of transportation infrastructure that benefits the welfare of Missouri citizens. A part of this responsibility is fulfilled through periodic inspections of highway structures, including bridges that span waterways throughout the State. At most of these structures, all or most of the structure can be fully inspected from land or from personnel lift trucks deployed from the roadway of the structure. However, 
for structures over major waterways, such as the Missouri and Mississippi Rivers, inspection of the part of the bridge that is underwater requires a different approach.

Beginning in 1991, the U.S. Geological Survey (USGS), in cooperation with MoDOT, has assessed scour at waterway crossings throughout the state (Huizinga and Rydlund, 2004). In 2007, the USGS began determining channel bathymetry and monitoring bridges for scour using single beam echo sounders and a multibeam mapping system (Rydlund, 2009; Huizinga and others, 2010). In particular, the multibeam mapping system has proven to be a useful tool not only in the determination of channel bathymetry, but also in providing medium- to high-resolution imagery of bridge structural elements below the water line. Therefore, the USGS, in cooperation with MoDOT, began conducting a series of bathymetric surveys at various highway bridges across major waterways in Missouri in 2010 .

Ten highway bridges and three railroad bridges span the Missouri River in the Kansas City, Missouri, area (table 1; fig. 1); the 10 highway bridges are under the responsibility of MoDOT. The U.S. Highway 69 crossing of the river consists of two bridges (structures K0456 and A0450), and the State Highway 291 crossing of the river consists of two bridges (structures A4757 and L0568). Therefore, 10 highway bridges at 8 unique crossings of the Missouri River in the Kansas City area routinely are inspected by MoDOT (Jennifer Harper, Missouri Department of Transportation, written commun., 2010).

Of the 10 highway bridges crossing the Missouri River in the Kansas City area, 9 were surveyed, as indicated in table 1. The Paseo Bridge (structure L0734; table 1; fig. 1) on Interstate 29/35 currently (2010) is in the process of being replaced with the Christopher S. Bond Bridge (kcICON Project, 2010) and, therefore, does not currently (2010) require an underwater inspection.

\section{Purpose and Scope}

The purpose of this report is to document bathymetric surveys of the Missouri River channel in the vicinity of nine highway bridges at seven crossings of the river in Kansas City, Missouri, obtained by using a multibeam echo sounder in 2010. Equipment and methods used and results obtained are described. The results obtained from the bathymetric surveys of the channel can be used to assess the bridges for stability and integrity issues with respect to bridge scour, and provide characteristics of scour holes that may be useful in the development of predictive guidelines or equations for scour holes.

\section{Description of Study Area}

The overall study area for this report is the Missouri River in Kansas City, Missouri (fig. 1). The Missouri River flows through the Kansas City area from west to east, meandering across the flood plain. The river is highly channelized in the Kansas City area, with rock revetment and spur dikes along the banks to maintain the channel alignment and levees and floodwalls on the upper banks to limit flooding in the industrial, commercial, and agricultural areas in the flood plains.

Table 1. Bridges crossing the Missouri River in the Kansas City, Missouri, area, in downstream order.

[MoDOT, Missouri Department of Transportation; IS, Interstate highway; --, not known/applicable; US, U.S. highway; S, southbound; N, northbound; BNSF, Burlington Northern Santa Fe; MO, State highway]

\begin{tabular}{|c|c|c|c|c|c|c|}
\hline $\begin{array}{l}\text { MoDOT } \\
\text { structure } \\
\text { number }\end{array}$ & Local name & County & Route & $\begin{array}{l}\text { Surveyed as } \\
\text { part of this } \\
\text { study }\end{array}$ & Remarks & Figures \\
\hline A1800 & Riverside & Platte & IS 635 & Yes & -- & $7,8,9,10,11$ \\
\hline K0456 & Fairfax & Platte & US $69 \mathrm{~S}$ & Yes & Dual bridge crossing with A0450 & $12,13,14,15$ \\
\hline A0450 & Fairfax Toll & Platte & US $69 \mathrm{~N}$ & Yes & Dual bridge crossing with K0456 & $12,13,14,16$ \\
\hline A4649 & Broadway Avenue & Clay & US 169 & Yes & -- & $17,18,19,20$ \\
\hline-- & Second Hannibal & Clay & BNSF & No & Railroad bridge & -- \\
\hline-- & ASB & Clay & BNSF & No & Railroad bridge & -- \\
\hline A4060 & Heart of America & Clay & MO 9 & Yes & -- & $21,22,23,24,25,26,27$ \\
\hline L0734 & Paseo & Clay & IS $29 / 35$ & No & Currently (2010) being replaced & -- \\
\hline A5817 & Chouteau & Clay & MO 269 & Yes & -- & $28,29,30,31,32$ \\
\hline A0767 & Randolph & Clay & IS 435 & Yes & -- & $33,34,35,36,37$ \\
\hline-- & Harry S Truman & Clay & BNSF & No & Railroad bridge & -- \\
\hline A4757 & Courtney & Jackson & MO $291 \mathrm{~S}$ & Yes & Dual bridge crossing with L0568 & $38,39,40,41$ \\
\hline L0568 & Courtney & Jackson & MO $291 \mathrm{~N}$ & Yes & Dual bridge crossing with A4757 & $38,39,40,42$ \\
\hline
\end{tabular}




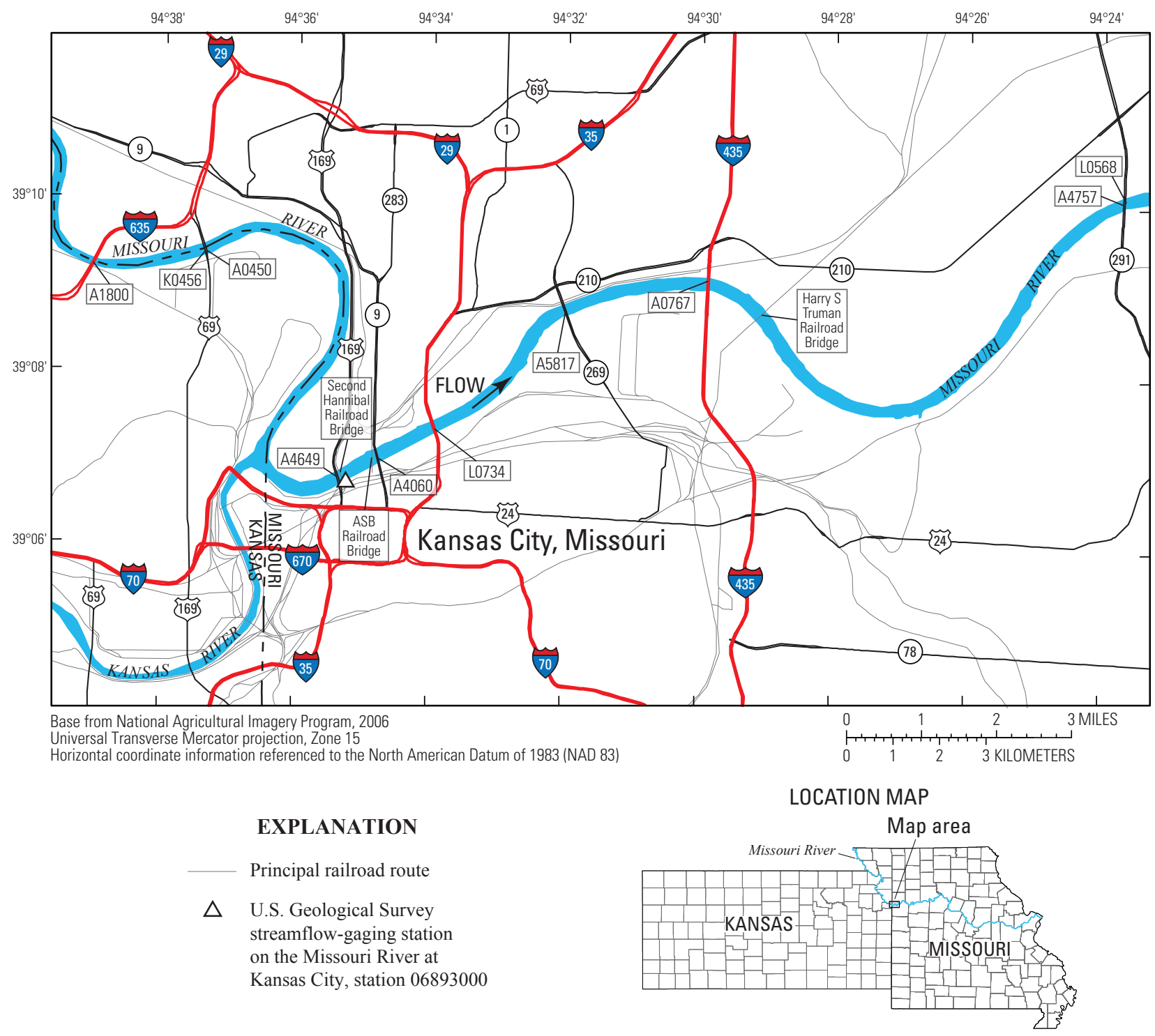

Figure 1. Location of bridges crossing the Missouri River in the Kansas City, Missouri, area.

\section{Equipment and Methods Used in Bathymetric Surveys}

The bathymetry of the Missouri River at each of the bridges was determined using a high-resolution multibeam mapping system. The various components of the multibeam mapping system used for this study are the same as used in a previous study on the Mississippi River near St. Louis, Missouri (Huizinga and others, 2010), and the survey methods used to obtain the data were similar, as were the measures used to ensure data quality. Nevertheless, the equipment and methods are discussed below for completeness.

\section{Description of Equipment}

A multibeam mapping system is an integration of several individual components: the multibeam echo sounder (MBES), a navigation and motion-sensing system, and a data collection and processing computer. The navigation system locates the MBES in three-dimensional space, and the motion-sensing system measures the heave, pitch, roll, and heading of the vessel (and, thereby, the MBES) to accurately position the data received by the MBES. The data from the MBES and navigation and motion-sensing components are processed and integrated into a cohesive dataset for cleanup and visualization by the data collection and processing computer. 


\section{Multibeam Echo Sounder}

The MBES that was used is the RESON SeaBat ${ }^{\mathrm{TM}} 7125$, which consists of projector and receiver arrays of piezoceramics (fig. $2 A$ ) operating at a frequency of 400 kilohertz $(\mathrm{kHz})$ attached to a fixed, tiltable head mounted on a retracting pole on the port side of the USGS survey boat (fig. 2). A soundvelocity probe (SVP-71; fig. $2 B$ ) also is attached to the head to measure the speed of sound in water near the projector and receiver arrays, which is critical to the accurate determination of depth (Hughes-Clarke and others, 1996; RESON, Inc., 2008; fig. 2B). Settings for and data from the MBES are processed through the RESON 7K Controller software (RESON, Inc., 2008) on the 7-P Sonar Processing Unit computer (hereinafter referred to as "the 7-P computer").

The projector and receiver arrays can operate in depths from 3 to 656 feet (ft). The projector array emits one sound wave that the receiver array forms into 512 equidistant beams with spacing of less than 0.25 degree $\left({ }^{\circ}\right)$ distributed across the ship track and $1^{\circ}$ wide along the track (fig. 3). This beam geometry can generate up to a $128^{\circ}$ swath that can cover up to 4.1 times the water depth across track (fig. 3 ) with up to 512 depth readings with each sounding. The head tilt bracket (fig. $2 B$ ) permits the head to be tilted to obtain soundings at shallower depths along river banks or on vertical walls or pier surfaces (fig. 4).

\section{Navigation and Motion-Sensing System}

The navigation and motion-sensing system that was used is the Applanix Position Orientation Solution for Marine Vessels (POS MV ${ }^{\mathrm{TM}}$ ) WaveMaster system (hereinafter referred to as "the POS"), which utilizes dual Trimble Zephyr Global Positioning System (GPS) antennae for navigation combined with an inertial motion unit (IMU) for vessel motion sensing. The POS is used to measure the vessel motion, so that data received from the MBES can be correctly positioned in three-dimensional space as the vessel rotates and moves on the water surface. Information from the dual GPS antennae on the boat is combined with a real-time kinetic (RTK) correction from a fixed GPS base station on the riverbank to provide a navigation and tide solution with an accuracy of 0.79 inch (in.) in the absence of structures that might block signal from the GPS constellation of satellites (Applanix Corporation, 2006). The IMU records vessel motion (pitch, roll, yaw, and heave) with an accuracy of $0.03^{\circ}$ for pitch, roll, and yaw, and 5 percent of the heave amplitude, or 1.96 in., whichever is greater (Applanix Corporation, 2006). The IMU also provides an inertial position solution that is reliable through RTK outages for periods of less than about 1 minute. Settings for and data from the POS are processed through the MV-POSView Controller software (Applanix Corporation, 2006) on the 7-P computer during the survey.

Because the bathymetric surveys were conducted at highway bridge crossings, the bridge structure would block a part or the entire signal from the GPS constellation of satellites when the survey vessel was near or under the bridge. These GPS outages had the potential to degrade the positional accuracy of the vessel until such time as an RTK-fixed navigation solution was re-acquired. However, the navigation information from the survey was post-processed using the POS-Pac ${ }^{\mathrm{TM}}$ Mobile Mapping Suite (MMS ${ }^{\mathrm{TM}}$ ) software (Applanix Corporation, 2009), which provided tools to identify and compensate for sensor and environmental errors and computed an optimally blended navigation solution from the GPS and IMU raw data. This blended navigation solution is called a "standard best-estimate of travel" (SBET) and represents the best-estimate of the motion of the vessel while minimizing the root mean square error of the estimated navigation solution. The SBET file generated by post-processing the navigation data was applied to the entire survey at a given bridge to minimize the effects of the GPS outages while surveying under the bridges.

\section{Data Collection and Processing Computer}

A laptop computer onboard the survey boat (hereinafter referred to as "the field computer") ran the HYPACK ${ }^{\circledR} /$ HYSWEEP $^{\circledR}$ data acquisition software (HYPACK, Inc., 2009) which was used to prepare for the bathymetric surveys, collect and process the survey data, and create various output products from the surveys. A map or other background image of the survey area was imported and used to plan and execute the survey. The bathymetric sounding data and the navigation and position solution collected and processed by the 7-P computer were transmitted by high-speed local area network (LAN) ethernet connection to the field computer. During the survey, the navigation and position solution from the POS was used to keep the survey boat on a proper heading by means of a helms display for the boat captain. Continual screen refreshing provided a low-resolution real-time map of the survey as it progressed, which permitted the immediate re-acquisition of data in areas that were missed during the survey.

Upon completion of the surveys, the acquired depth data were processed using the HYPACK ${ }^{\circledR} / \mathrm{HYSWEEP}^{\circledR}$ software to remove data spikes and other spurious points in the multibeam swath trace, using a variety of tools and filters to identify and selectively remove potential erroneous data points. After cleanup, the depth data were georeferenced using the navigation and position solution data from the SBET file from POS-Pac ${ }^{\mathrm{TM}}$ MMS $^{\mathrm{TM}}$, and were visualized in HYPACK ${ }^{\circledR /}$ HYSWEEP $^{\circledR}$ as a triangulated irregular network (TIN) surface or a point cloud.

The georeferenced data also were output to a commadelimited file with no data reduction or filtered and reduced based on a desired data resolution. These comma-delimited data were compiled into a geographic information system (GIS) database for each site using the ArcGIS package (Environmental Systems Research Institute, 2010). ArcGIS is a collection of software packages that allow data editing and attribution, data display and review, data processing, generation of interpolated of data, and map-product creation (Wilson and Richards, 2006). 

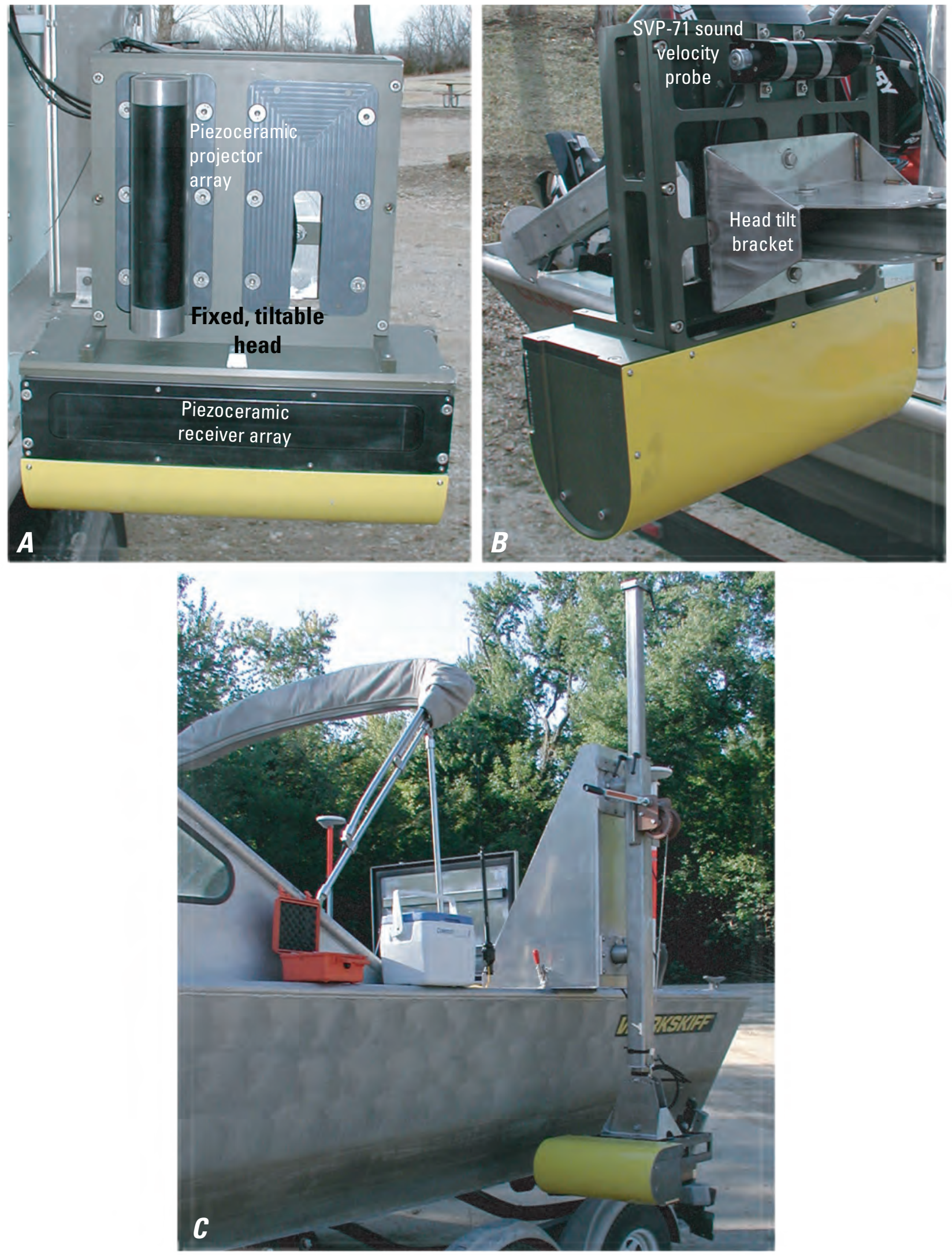

Figure 2. The multibeam echo sounder as viewed $A$, from the bottom, $B$, from the top, and $C$, mounted on the port side of the U.S. Geological Survey boat. 


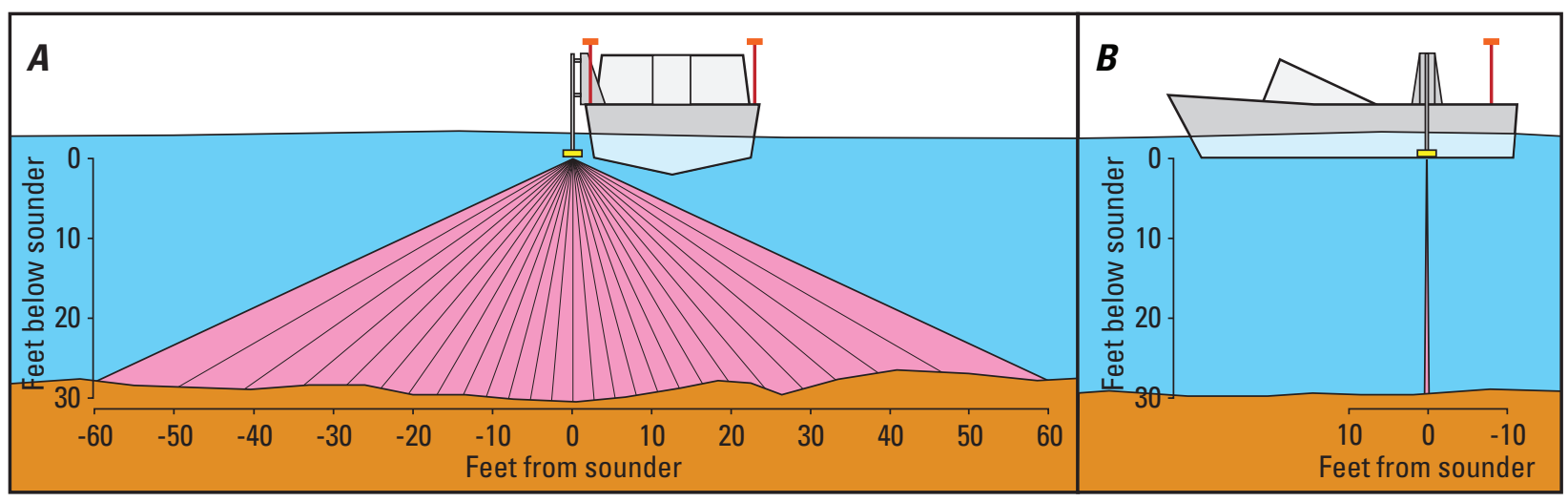

Figure 3. Approximate beam geometry of the multibeam echo sounder $A$, across ship track and $B$, along ship track.

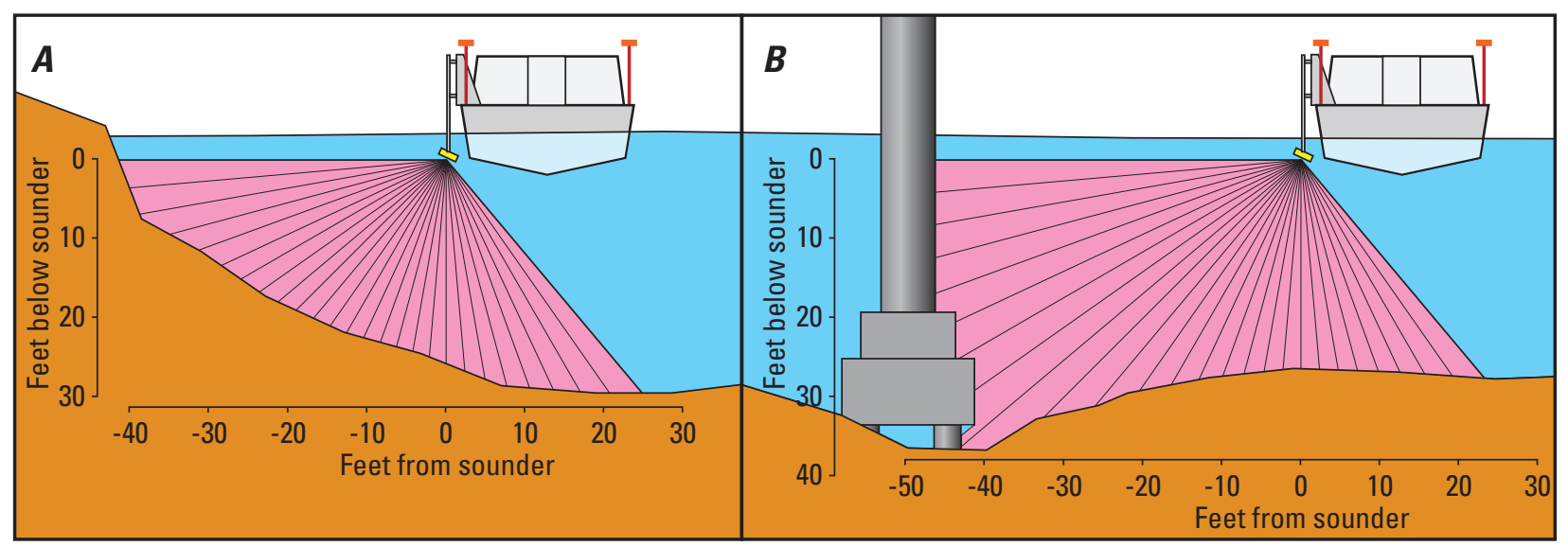

Figure 4. Approximate beam geometry of the multibeam echo sounder with a tilted head to obtain soundings $A$, along a river bank or $B$, on the side of a vertical structure.

\section{Description of Survey Methods}

The GPS base station used for the RTK navigation and tide solution during the survey was set up on the river bank, near the bridge to be surveyed. In general, the surveyed area extended bank to bank in the main channel of the river and was from 1,640 to 1,800 $\mathrm{ft}$ long, positioned so that the surveyed highway bridge was approximately one-third to one-half of the total length from the upstream boundary. The boundaries of the surveyed area were assumed to be beyond the hydraulic effect of the bridge structure.

To ensure complete coverage of the channel bed and minimize sonic "shadows," each survey was designed so that there was overlap of the survey swaths. Sonic "shadows" occur when a tall feature present in the water column prevents soundings behind the object (fig. 5). Survey lines were spaced at 49.2-ft intervals across the survey area orthogonal to the flow direction at each bridge. Data were not acquired along every survey line at a given bridge site, but the survey lines were used to orient the boat during data acquisition. Knowing that the beam geometry of the MBES provides a swath width that is approximately 4.1 times the water depth across track (fig. 3), the boat was positioned so that there was about 50 percent overlap with the adjacent surveyed data, which provided about 150 percent coverage of the channel bed and ample coverage on both sides of any feature that might create a sonic "shadow" (fig. 5). Substantial overlap was achieved for all of the surveyed swaths, except in shallow areas near the channel banks on the inside of channel bends or near debris rafts. Because of the overlap, the outermost beams generally were removed from a given swath without compromising coverage. The outer beams were most susceptible to small errors in boat position and attitude or the effects of refraction (HughesClarke and others, 1996).

Channel-bed coverage along a given survey line is dependent on the speed of the vessel relative to the channel bottom (hereinafter referred to as "absolute boat speed") and the dataacquisition rate (hereinafter referred to as "ping rate") of the MBES. In the riverine environment, the survey boat requires enough forward velocity to overcome the current and travel upstream, whereas on downstream passes, the survey boat has to have enough velocity to enable steering. Therefore, the survey boat always has greater absolute boat speed traveling downstream than traveling upstream. To provide equivalent 


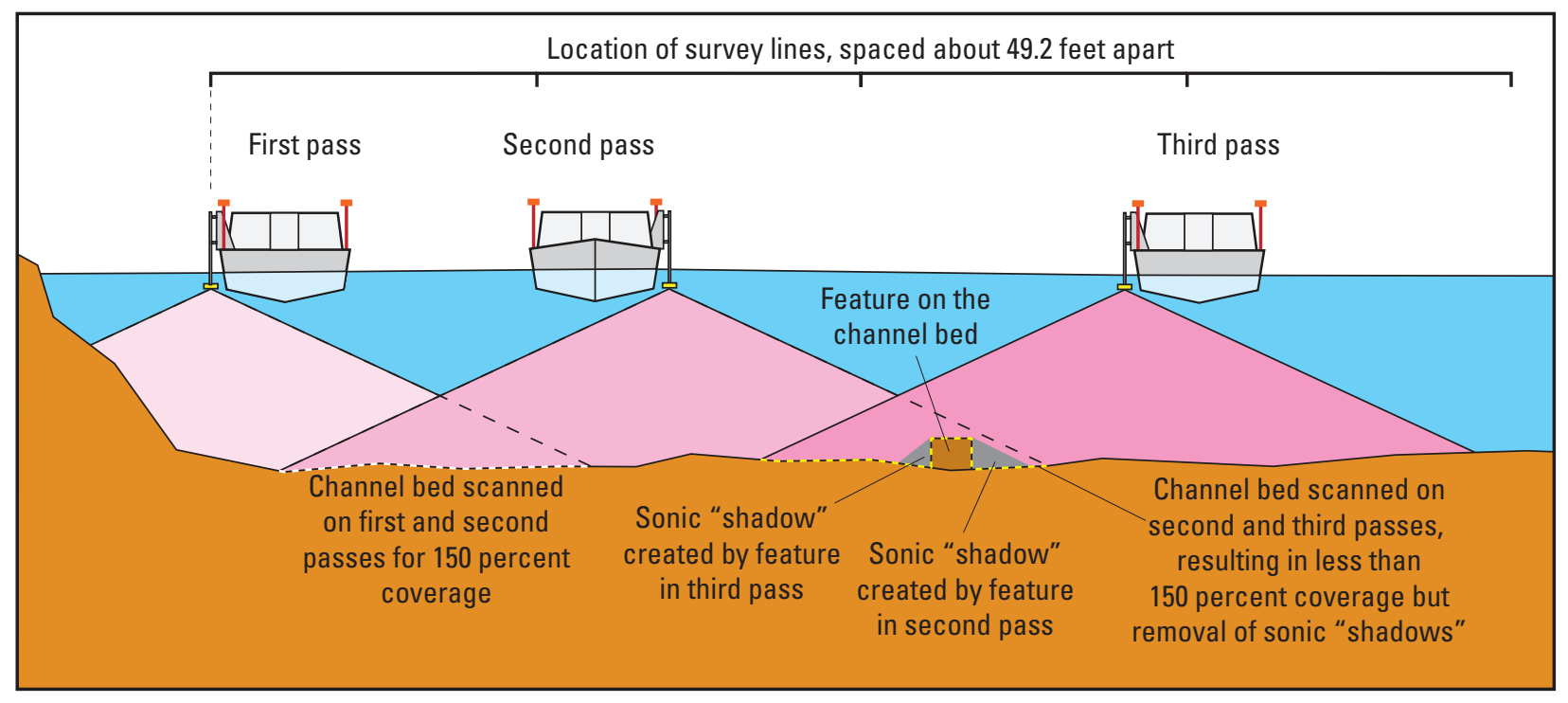

Figure 5. Method of survey line spacing used to ensure complete coverage of the channel bed and minimize sonic "shadows."

coverage in the upstream and downstream directions, the ping rate of the MBES was altered relative to the absolute boat speed to generate one ping approximately every $0.5 \mathrm{ft}$.

The Missouri River was in moderate flood conditions from rainfall and snowmelt when the bathymetric surveys were performed March 15 through 18, 2010. The discharge ranged from 120,000 to 129,000 cubic feet per second $\left(\mathrm{ft}^{3} / \mathrm{s}\right)$, as measured at the USGS streamflow-gaging station (hereinafter referred to as "streamgage") on the Missouri River at Kansas City, Missouri (station 06893000), on the Second Hannibal railroad bridge (U.S. Geological Survey, 2010) - a discharge exceeded daily less than 5 percent of the time (U.S. Geological Survey, 2003), but less than the 50 percent annual exceedance probability (2-year return interval) flood discharge of $142,000 \mathrm{ft}^{3} / \mathrm{s}$ (U.S. Army Corps of Engineers, 2004a). Because of the higher stage, surveys from bank to bank generally were possible in the main channel with sufficient depth to clear rock spur dikes and other flow structures. However, strong flow velocity in the channel thalweg made headway against the current difficult; therefore, the channel thalweg generally was surveyed downstream, and upstream passes were made away from the thalweg. The presence of flood debris rafts made surveying difficult or impossible at some piers.

Because knowledge of the speed of sound in water is critical to the accurate measurement of distances using a MBES (Hughes-Clarke and others, 1996), routine sound-velocity profile casts are taken during surveys in lakes or oceans to determine the presence of thermoclines and accurately measure the speed of sound throughout the water column. However, in the riverine environment, flow mixing is assumed to maintain a constant speed of sound throughout the water column. The riverine speed of sound, as measured by the SVP-71, was monitored during the survey at a given bridge, and generally did not deviate by more than 0.05 percent during the survey. Nevertheless, occasional pockets of warmer water were encountered near outfalls from tributaries. When one of these pockets was encountered, it changed the speed of sound as measured by the SVP-71 on the MBES transducer head (fig. $2 B$ ), which invariably altered the measured depth to the channel bed for the duration of several pings of the MBES. However, the location of these warmer pockets generally was away from the substructural elements of the surveyed bridge. The altered depths near these outfalls were not edited if the effect was small compared to nearby unaffected depths, or the swaths containing the altered depths were removed.

\section{Survey Quality-Assurance/Quality-Control Measures}

For the MBES mapping system, the principal qualityassurance assessments were performed in real time during the survey. The MBES operator was continuously assessing the quality of the collected data during the survey, making visual observations of across-track swaths (such as convex, concave, or skewed bed returns in flat, smooth bottoms), noting data quality flags and alarms from the MBES and the POS, and noting comparisons between adjacent overlapping swaths. However, in addition to the real-time quality-assurance assessments during the survey, several tests were performed to ensure the quality of the data acquired by the MBES mapping system. For this survey, a beam angle check and a suite of patch tests were performed to ensure quality data were acquired from the MBES mapping system.

\section{Beam Angle Check}

A beam angle check is used to determine the accuracy of the depth readings obtained by the outer beams of the MBES (U.S. Army Corps of Engineers, 2004b). The HYPACK ${ }^{\circledR}$ 
HYSWEEP $^{\circledR}$ software has a program that will perform a statistical assessment of the quality of the outer beams compared to a reference surface. On March 18, 2010, a reference surface was created for a portion of Blue Springs Lake near Blue Springs, Missouri [on the southeastern side of Kansas City about 11 miles south-southwest of structures A4754 and L0568 on State Highway 291 (fig. 1)], and check lines were run across the reference surface.

The results of the beam angle check (table 2) were within the recommended standards utilized by the U.S. Army Corps of Engineers for hydrographic surveys for angles less than $60^{\circ}$ from nadir (U.S. Army Corps of Engineers, 2004b). To mitigate errors associated with depths for angles greater than $60^{\circ}$ from nadir, these points were removed from the swath for survey lines in the deep part of the channel. These points were not removed in shallow areas because the relative effect of depth errors is lessened, and the channel bed coverage was more likely to be compromised by removal of the points.

\section{Patch Tests}

Patch tests are a series of dynamic calibration tests that are used to check for subtle variations in the orientation and timing of the MBES with respect to the POS and real world coordinates. The patch tests are used to determine timing offsets caused by latency between the MBES and the POS, and angular offsets to roll, pitch, and yaw caused by the alignment of the transducer head (fig. 6). A set of patch tests was performed each day of surveying, and a summary of the results is shown in table 3.

A latency test measures the timing offset between the MBES and the GPS components of the POS, $\Delta$ t (fig. $6 A$ ). In a latency test, a line that is perpendicular to a slope or distinct feature on the channel bed is surveyed twice in the same direction, but at slow and fast vessel speeds. Errors will appear as a horizontal offset in the slope or feature between the two surveyed lines. For this set of surveys, there was no measured timing offset $(\Delta t=0$; table 3$)$, which is consistent with latency test results for this boat and configuration used in other surveys (Huizinga and others, 2010; Richard Huizinga, U.S. Geological Survey, unpub. data, 2010).

A roll test measures the angular offset of the transducer head along the longitudinal axis of the boat, $\alpha$ (fig. $6 B$ ), which leads to horizontal and vertical position errors of a measured channel-bed point. In a roll test, a line over a relatively flat channel bed is surveyed twice in opposite directions at the same speed. An angular offset for roll error will cause the flat bed to appear sloped in opposing directions across the reciprocal lines. For the March 2010 surveys, the measured angular offset for roll ranged from $0.21^{\circ}$ to $0.29^{\circ}$ (table 3 ) from the first day of surveying to the last, which indicates that the transducer head was bending during the week of surveying. Examination of the transducer head after the surveys confirmed that the head tilt bracket (fig. $2 B$ ) had been slightly bent. Because the bending appeared to have occurred

Table 2. Results of a beam angle check from two check lines over a reference surface at Blue Springs Lake, Missouri, on March 18, 2010.

$[\mathrm{ft}$, feet; $<$, less than: --, no data]

\begin{tabular}{ccccc}
\hline $\begin{array}{c}\text { Beam angle } \\
\text { limit } \\
\text { (degrees) }\end{array}$ & $\begin{array}{c}\text { Maximum } \\
\text { outlier } \\
\text { (ft) }\end{array}$ & $\begin{array}{c}\text { Mean } \\
\text { difference } \\
\text { (ft) }\end{array}$ & $\begin{array}{c}\text { Standard } \\
\text { deviation } \\
\text { (ft) }\end{array}$ & $\begin{array}{c}\text { 95 percent } \\
\text { confidence } \\
\text { (ft) }\end{array}$ \\
\hline 20 & 0.85 & 0 & 0.10 & 0.20 \\
25 & .85 & 0 & .10 & .16 \\
30 & .85 & 0 & .10 & .16 \\
35 & .85 & 0 & .10 & .16 \\
40 & .85 & 0 & .10 & .16 \\
45 & .92 & 0 & .10 & .16 \\
50 & .92 & 0 & .10 & .16 \\
55 & .92 & 0 & .10 & .16 \\
60 & 1.02 & 0 & .10 & .20 \\
65 & 1.77 & -.03 & .13 & .26 \\
70 & 1.77 & -.03 & .16 & .30 \\
& & & & \\
Performance standards ${ }^{\mathrm{a}}$ & 1.00 & $<.20$ & -- & $<.50$ \\
Within standards & Yes, $<60$ degrees & Yes & -- & Yes \\
\hline
\end{tabular}

aPerformance standard check values are from U.S. Army Corps of Engineers (2004b), table 3-1. 


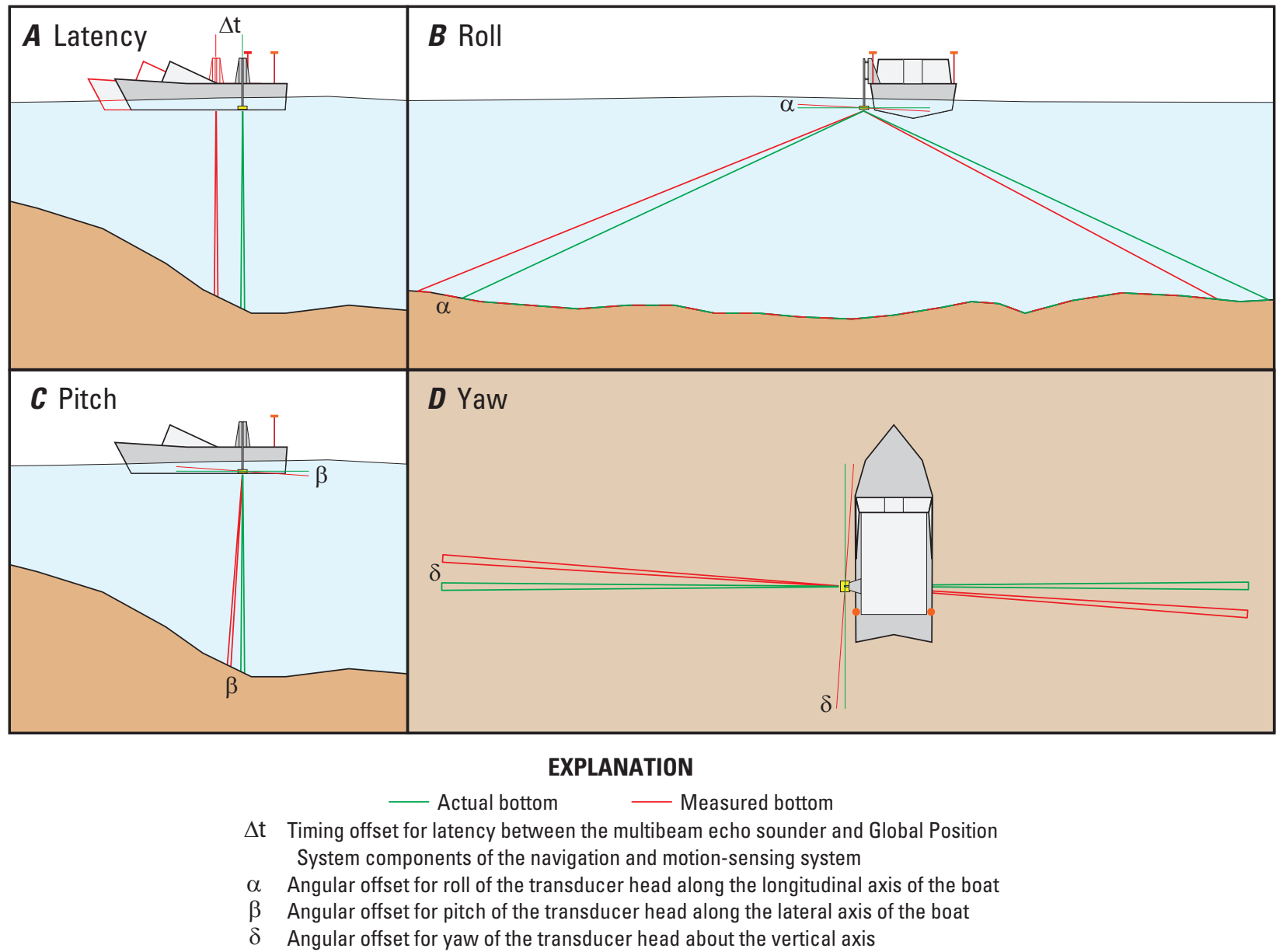

Figure 6. Effects of timing and angular offsets for $A$, latency, $B$, roll, $C$, pitch, and $D$, yaw on data from a multibeam echo sounder.

Table 3. Results of patch tests performed each day of surveying on the Missouri River in Kansas City, Missouri, and at Blue Springs Lake, Missouri.

[sec, seconds; deg, degrees; IS, Interstate highway; US, U.S. highway; MO, State highway]

\begin{tabular}{cccccc}
\hline Date of test & $\begin{array}{c}\text { Timing } \\
\text { offset } \\
\text { (sec) }\end{array}$ & $\begin{array}{c}\text { Angular } \\
\text { offset for } \\
\text { roll } \\
\text { (deg) }\end{array}$ & $\begin{array}{c}\text { Angular } \\
\text { offset for } \\
\text { pitch } \\
\text { (deg) }\end{array}$ & $\begin{array}{c}\text { Angular } \\
\text { offset for } \\
\text { yaw } \\
\text { (deg) }\end{array}$ & Location \\
\hline $03 / 15 / 10$ & 0 & 0.21 & -1.80 & 2.80 & $\begin{array}{c}\text { Missouri River in Kansas City, between } \\
\text { IS 635 and US 69 }\end{array}$ \\
$03 / 16 / 10$ & 0 & .23 & -1.80 & 2.50 & $\begin{array}{c}\text { Missouri River in Kansas City, between } \\
\text { US 169 and MO } 9\end{array}$ \\
$03 / 17 / 10$ & 0 & .25 & -1.80 & 2.50 & $\begin{array}{c}\text { Missouri River in Kansas City, between } \\
\text { MO 269 and IS 435 }\end{array}$ \\
$03 / 18 / 10$ & 0 & .29 & -1.80 & 2.50 & Blue Springs Lake, Missouri \\
\hline
\end{tabular}


gradually, the angular offset for roll value obtained during the patch test on a given day was assumed to apply to all the data collected on that day. Using an average angular offset for roll value for each day (rather than an average value for the 4 days of surveying) minimized any error in the head position introduced by the bending mount. The daily values are consistent with angular offset for roll values determined for this boat during previous surveys (Richard Huizinga, unpub. data, 2010).

A pitch test measures the angular offset of the transducer head in a forward or aft direction along the lateral axis of the boat, $\beta$ (fig. $6 C$ ), which leads to horizontal position errors of a measured channel-bed point. In a pitch test, a line that is perpendicular to a slope or distinct feature on the channel bed is surveyed twice in opposite directions at the same speed. An angular offset for pitch error will appear as a horizontal offset in the slope or feature between the reciprocal lines. For the March 2010 surveys, the measured angular offset for pitch equaled a constant value of $-1.80^{\circ}$ (table 3 ), which is consistent with the angular offset for pitch value determined for this boat during a previous survey (Richard Huizinga, unpub. data, 2010). The bending of the mount did not appear to affect the angular offset for pitch.

A yaw test measures the angular offset of the transducer head in terms of its rotation about the vertical axis, $\delta$ (fig. $6 D$ ), which results in horizontal position errors of a measured channel-bed point for points in the outer beams. In a yaw test, two lines perpendicular to a slope or distinct feature on the channel bed are surveyed in the same direction at the same speed. An angular offset for yaw error will appear as a horizontal offset in the slope or feature in the area between the surveyed lines. For the March 2010 surveys, the measured angular offset for yaw was $2.80^{\circ}$ on the first day of surveying, and was $2.50^{\circ}$ for the other days (table 3 ). These values are somewhat inconsistent with angular offset for yaw values determined for this boat during previous surveys (Richard Huizinga, unpub. data, 2010), and likely is the result of the bending mount. However, a sensitivity analysis of the four offsets implied that the ultimate position of surveyed points in three-dimensional space was least sensitive to the angular offset for yaw, whereas it was most sensitive to the angular offset for roll (HYPACK, Inc., 2009).

\section{Results of Bathymetric Surveys}

The bathymetric data were processed to apply the patch test corrections for each day of surveying and to remove data spikes and other spurious points in the multibeam swaths. The bathymetric data were then projected to a three-dimensional grid at a resolution of $0.82 \mathrm{ft}$ (high resolution) near the bridge pier(s) and $3.28 \mathrm{ft}$ (low resolution) for the remainder of the surveyed area. The bathymetric data were used to generate a TIN of the channel bed in the vicinity of each bridge using ArcGIS. At structure A1800 on Interstate 635, structure A4060 on State Highway 9, and structure A0767 on Interstate 435, the higher resolution data around the main channel piers were obtained with a tilted transducer head after all the other channel bathymetric data were obtained for that day. This time difference resulted in a difference in the channel-bed elevations between the data sets, which is most noticeable along the boundary between the data sets.

The site-specific results for each bridge are discussed in the following sections starting with the upstream-most bridge site and progressing downstream, followed by a discussion of general findings that are not site specific. All discharge values are from the USGS streamgage on the Missouri River at Kansas City, Missouri (station 06893000), located on the downstream side of the Second Hannibal railroad bridge (fig. 1). All elevation data were referenced to the North American Vertical Datum of 1988 (NAVD 88). The difference between NAVD 88 and the National Geodetic Vertical Datum of 1929 (NGVD 29) used in MoDOT bridge plans ranged from 0.26 to $0.28 \mathrm{ft}$ (NAVD 88 minus NGVD 29) throughout the Kansas City area, with an average value of $0.27 \mathrm{ft}$.

At seven of the nine bridges, a Level II scour assessment (Lagasse and others, 1991) was performed in 2002 (Huizinga and Rydlund, 2004). A Level II scour assessment is an application of hydrologic, hydraulic, and sediment transport concepts to determine qualitative scour-depth estimates, and includes obtaining the cross section of the channel on the downstream side of the bridge. The surveyed channel bed from this study was compared to the channel bed at the time of the Level II assessment in 2002, where applicable. 


\section{Structure A1800 on Interstate 635}

Structure A1800 is on Interstate 635 on the northwestern side of Kansas City, Missouri (figs. 1, 7). The survey was conducted on March 15, 2010, and the average water-surface elevation of the river in the survey area determined by the RTK GPS tide solution was $734.83 \mathrm{ft}$ (table 4). Flow on the Missouri River was about $129,000 \mathrm{ft}^{3} / \mathrm{s}$ during the survey (table 4).

The survey area was about 1,640 ft long and about $700 \mathrm{ft}$ wide, extending from bank to bank in the main channel (fig. 8). The upstream end of the survey area was about $720 \mathrm{ft}$ upstream from the centerline of structure A1800 (figs. 7, 8). The channel-bed elevations ranged from about 694 to $728 \mathrm{ft}$. A deep thalweg along the outside of the river bend on the right (south) bank was about $25 \mathrm{ft}$ deeper than the channel bed on the inside of the bend on the left (north) bank (fig. 8). Several large dune features were detected in the middle of the channel, as well as a localized deep hole in the middle of the downstream channel (fig. 8). Numerous smaller dunes and ripples were along the left (north) bank on the inside of the river bend and in the channel thalweg on the right (south) side (fig. 8).

In the vicinity of the main channel pier (pier 3, fig. 9), a scour hole had a minimum elevation of about $693 \mathrm{ft}$ (table 4), about $18 \mathrm{ft}$ below the average channel bed immediately upstream from the pier and $9 \mathrm{ft}$ below the elevation of the bottom of the pier seal course of $702.28 \mathrm{ft}$ (fig. 10; table 5). Information from bridge plans indicates that the main channel pier of structure A1800 is founded on shafts drilled $20 \mathrm{ft}$ into bedrock, with about $41 \mathrm{ft}$ of bed material between the bottom of the scour hole and bedrock (table 5). A point cloud visualization of the multibeam depth points obtained during the survey indicated the bottom of the seal course as a sonic "shadow" (fig. 11).

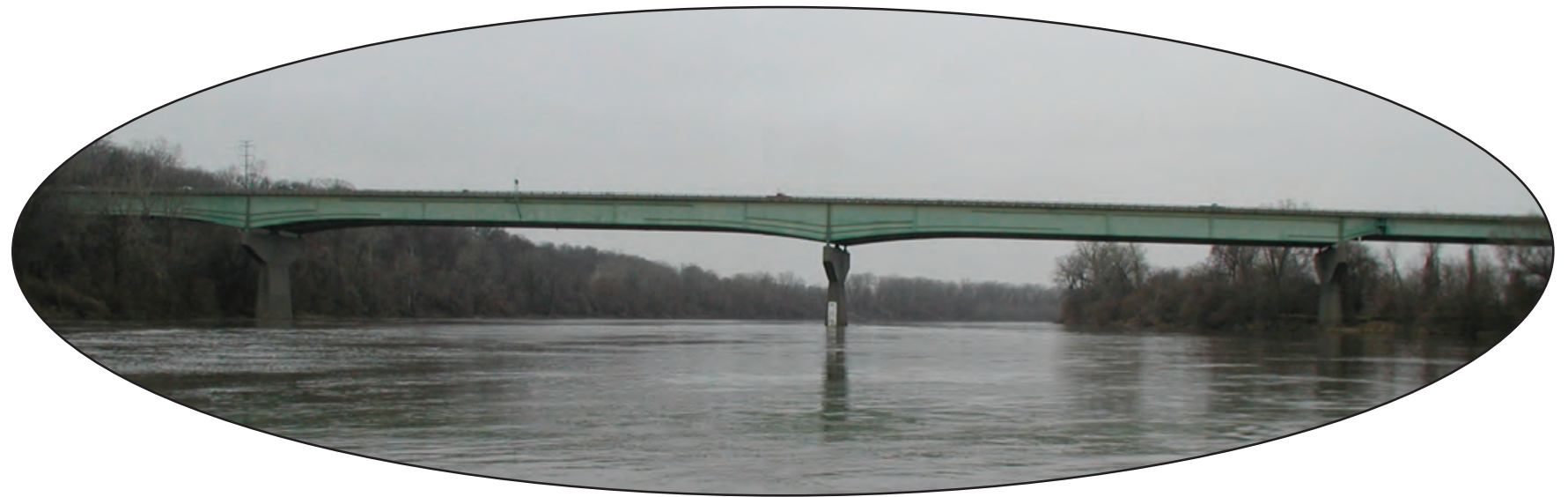

Structure A1800 on Interstate 635.

Table 4. Bridge and survey information and minimum elevations in the channel and scour holes from surveys on the Missouri River in Kansas City, Missouri, from March 15-18, 2010.

[MoDOT, Missouri Department of Transportation; $\mathrm{ft}^{3} / \mathrm{s}$, cubic feet per second; $\mathrm{ft}$, feet; IS, Interstate highway; US, U.S. highway; MO, State highway; all elevations are in feet above the North American Vertical Datum of 1988]

\begin{tabular}{|c|c|c|c|c|c|c|c|c|}
\hline $\begin{array}{c}\text { MoDOT } \\
\text { structure } \\
\text { number }\end{array}$ & $\begin{array}{l}\text { Survey } \\
\text { date }\end{array}$ & Route & $\begin{array}{l}\text { River } \\
\text { mile }\end{array}$ & $\begin{array}{c}\text { Discharge }^{\mathrm{a}} \\
\quad\left(\mathrm{ft}^{3} / \mathrm{s}\right)\end{array}$ & $\begin{array}{l}\text { Average water- } \\
\text { surface elevation } \\
\text { in vicinity of } \\
\text { bridge } \\
\text { (ft) }\end{array}$ & $\begin{array}{l}\text { Approximate } \\
\text { minimum } \\
\text { channel } \\
\text { elevation } \\
\text { (ft) }\end{array}$ & $\begin{array}{c}\text { MoDOT } \\
\text { pier } \\
\text { number }\end{array}$ & $\begin{array}{l}\text { Approximate } \\
\text { minimum } \\
\text { elevation in } \\
\text { scour hole } \\
\text { (ft) }\end{array}$ \\
\hline A1800 & $03 / 15 / 10$ & IS 635 & 374.09 & 129,000 & 734.83 & 694 & 3 & 693 \\
\hline K0456/A0450 & $03 / 15 / 10$ & US 69 & 372.58 & 129,000 & 733.67 & 688 & $7 / 9$ & 672 \\
\hline A4649 & $03 / 16 / 10$ & US 169 & 366.20 & 127,000 & 727.85 & 685 & 2 & 675 \\
\hline \multirow[t]{2}{*}{ A 4060} & 03/16/10 & MO 9 & 365.52 & 126,000 & 727.05 & 688 & 6 & 689 \\
\hline & & & & & & & 5 & 691 \\
\hline A5817 & $03 / 17 / 10$ & MO 269 & 362.25 & 124,000 & 724.05 & 679 & 2 & 685 \\
\hline A0767 & $03 / 17 / 10$ & IS 435 & 360.26 & 123,000 & 722.52 & 682 & 7 & 679 \\
\hline A4757/L0568 & 03/18/10 & MO 291 & 352.73 & 120,000 & 717.20 & 676 & $2 \mathrm{C} / 5$ & 661 \\
\hline
\end{tabular}

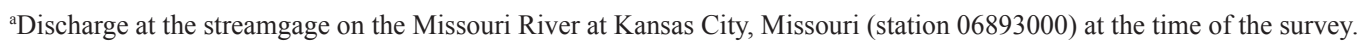

${ }^{\mathrm{b}}$ The minimum channel elevation excluding scour holes near the bridge, typically in the channel thalweg.

${ }^{\mathrm{c}}$ The point of lowest elevation in the scour hole near the bridge pier, not necessarily at the upstream pier face. 


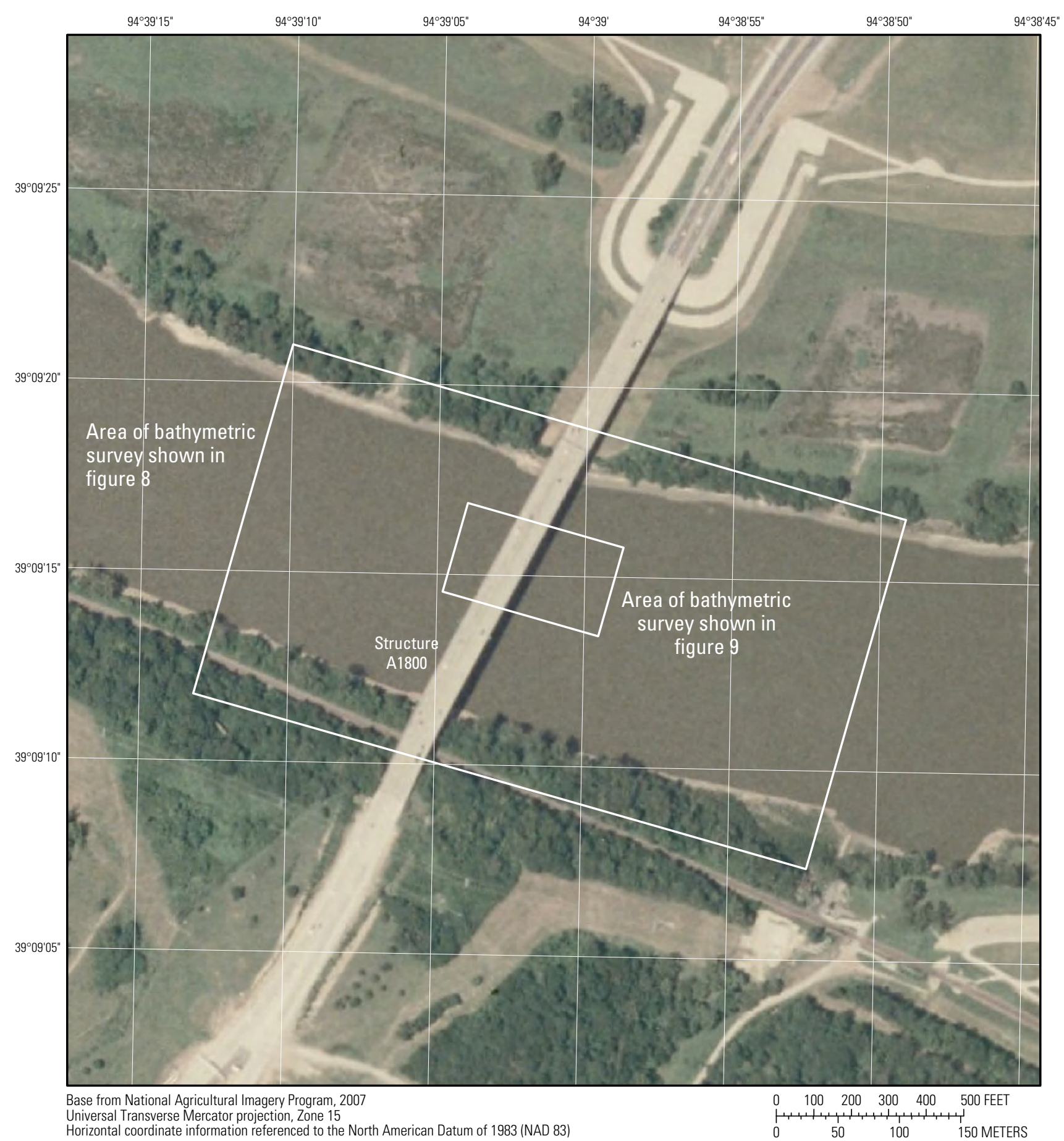

Figure 7. Location of the bathymetric survey area on the Missouri River near structure A1800 on Interstate 635 in Kansas City, Missouri. 


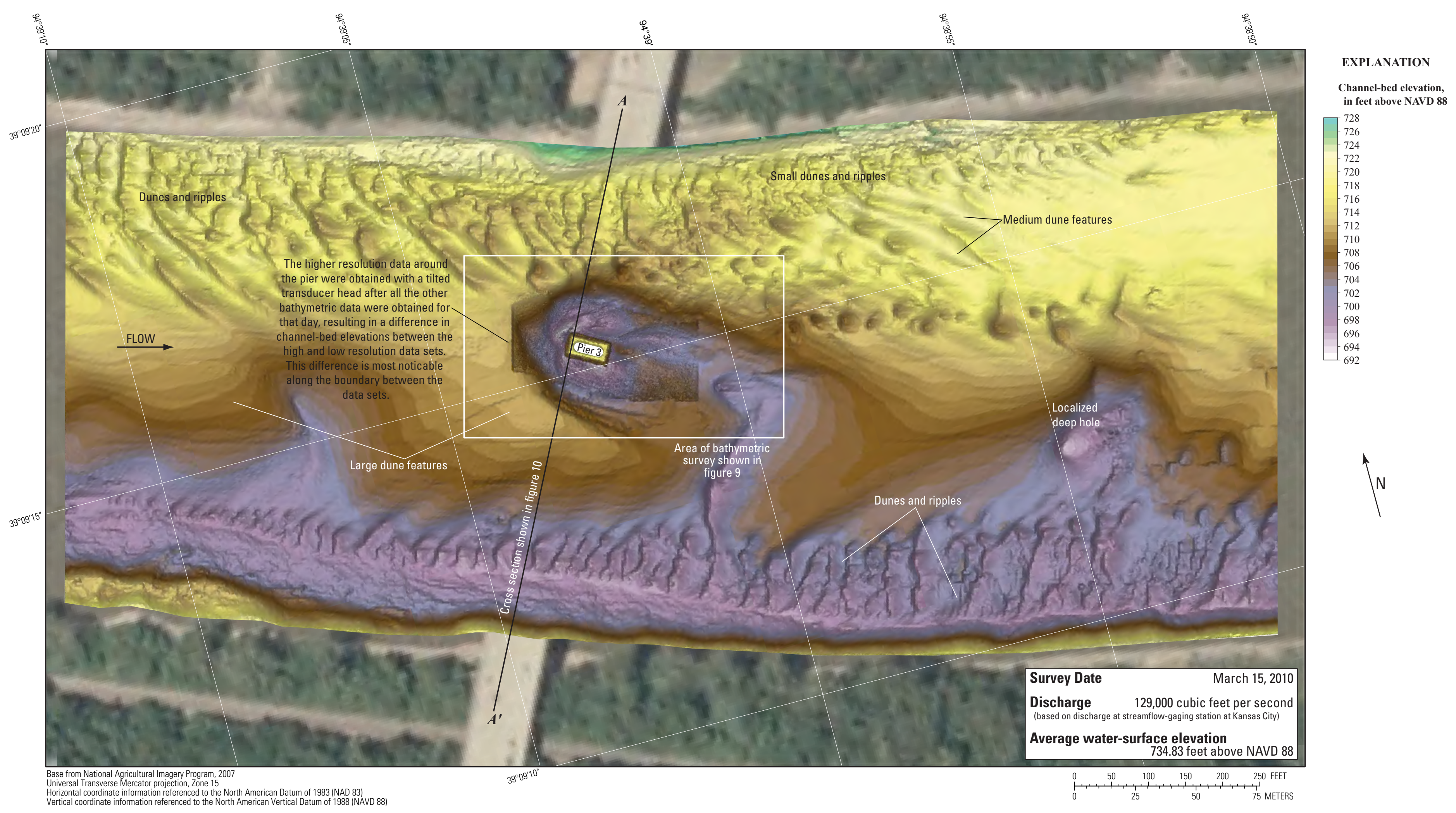

Figure 8. Bathymetric survey of the Missouri River channel in the vicinity of structure A1800 on Interstate 635 in Kansas City, Missouri 


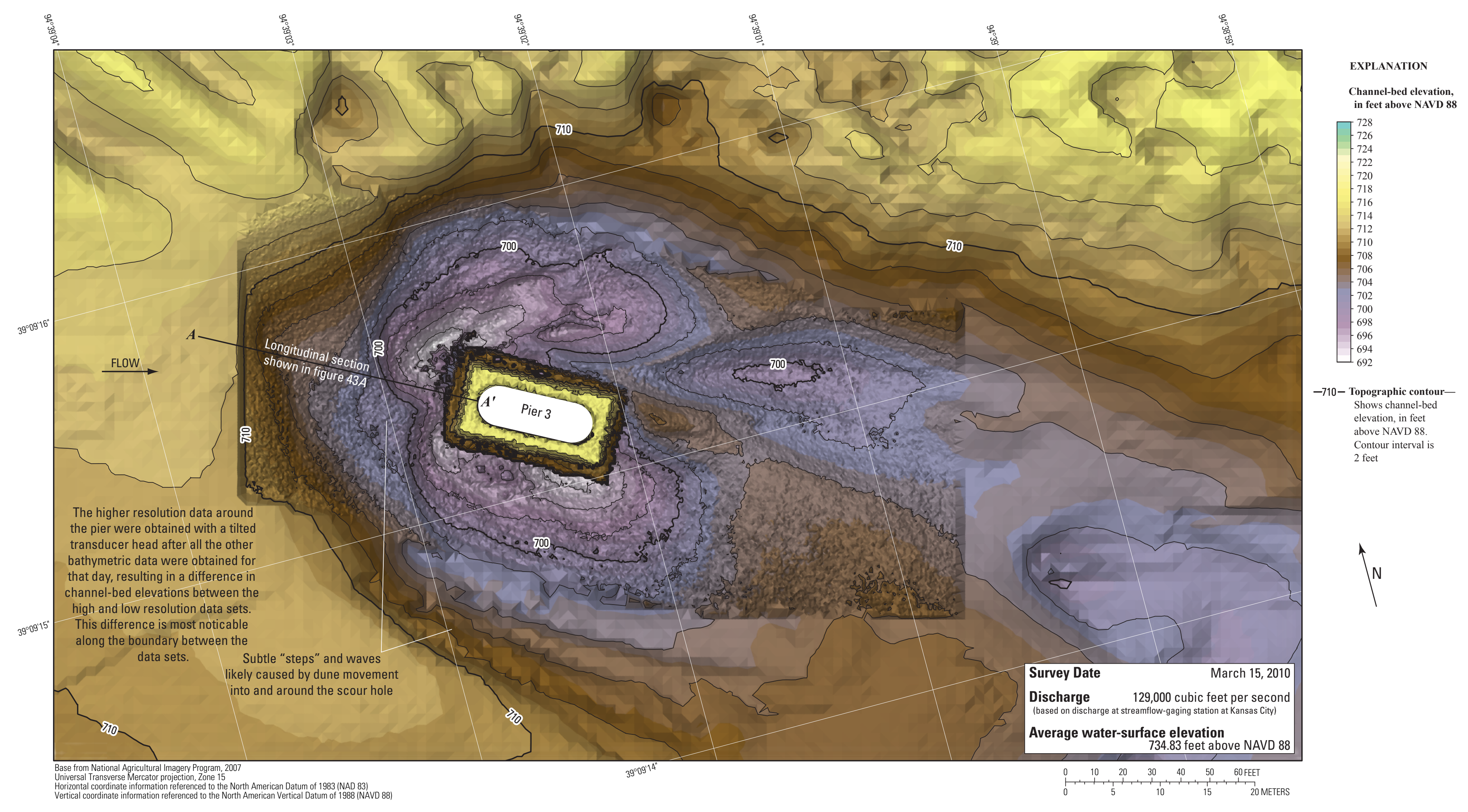

Figure 9. Bathymetric survey of the Missouri River channel in the vicinity of the main channel pier of structure A1800 on Interstate 635 in Kansas City, Missouri. 


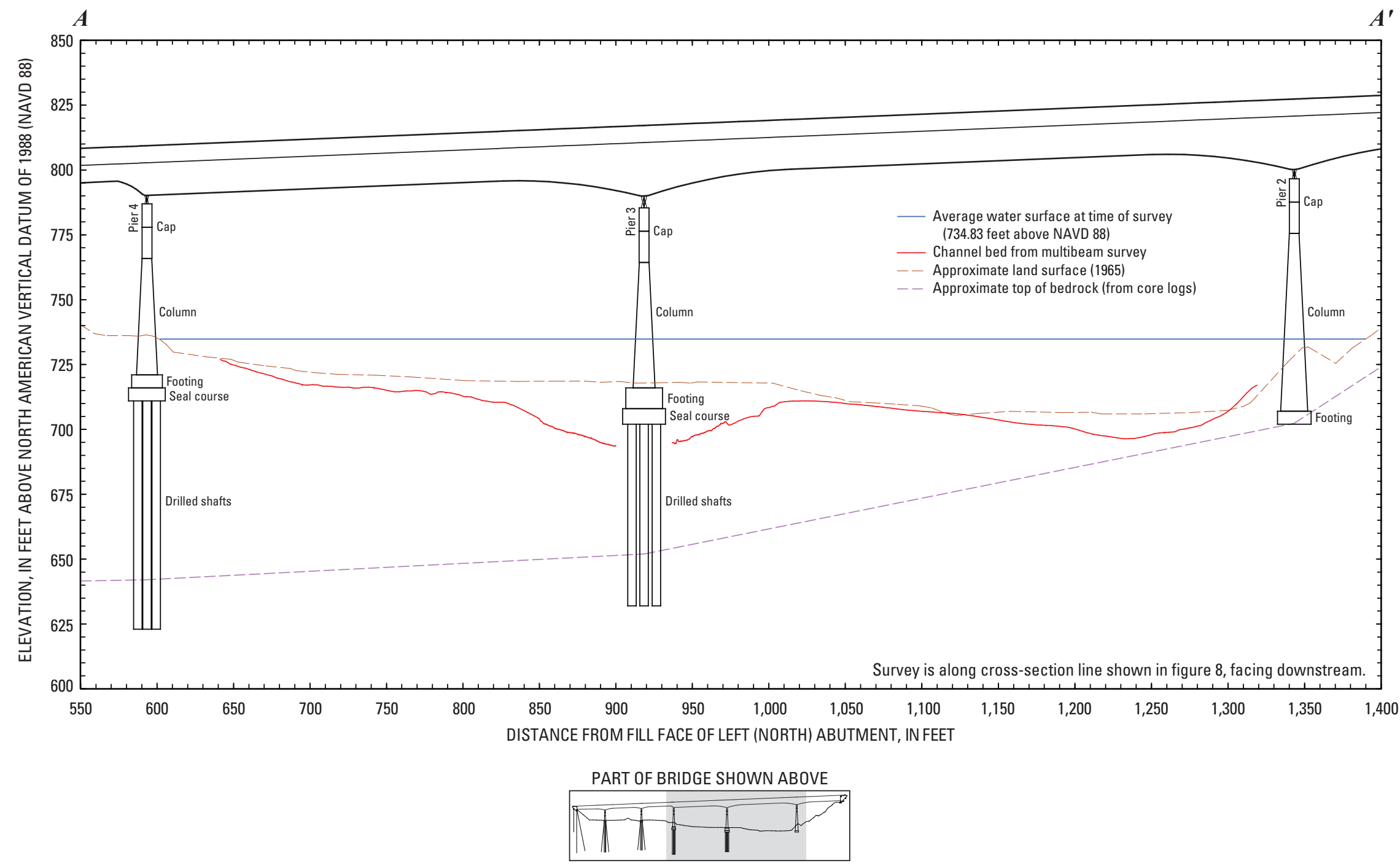

Figure 10. Key features, substructural and superstructural details, and surveyed channel bed of structure A1800 on Interstate 635 over the Missouri River in Kansas City, Missouri. 
Table 5. Results at upstream pier faces from surveys on the Missouri River in Kansas City, Missouri, from March 15-18, 2010.

[MoDOT, Missouri Department of Transportation; ft, feet; --, not known/applicable; all elevations are in feet above the North American Vertical Datum of 1988]

\begin{tabular}{|c|c|c|c|c|c|c|c|c|c|c|}
\hline \multirow[b]{2}{*}{$\begin{array}{l}\text { MoDOT } \\
\text { structure } \\
\text { number }\end{array}$} & \multirow[b]{2}{*}{$\begin{array}{l}\text { MoDOT } \\
\text { pier } \\
\text { number }\end{array}$} & \multicolumn{4}{|c|}{ Foundation information } & \multirow[b]{2}{*}{$\begin{array}{c}\text { Approximate } \\
\text { elevation of } \\
\text { scour hole } \\
\text { (ft) }\end{array}$} & \multirow[b]{2}{*}{$\begin{array}{c}\text { Approximate } \\
\text { elevation of } \\
\text { bedrock } \\
\text { (ft) }\end{array}$} & \multirow[b]{2}{*}{$\begin{array}{c}\text { Approximate } \\
\text { distance between } \\
\text { bottom of scour } \\
\text { hole and bedrock } \\
\text { (ft) }\end{array}$} & \multirow[b]{2}{*}{$\begin{array}{l}\text { Depth of scour } \\
\text { hole from } \\
\text { upstream } \\
\text { channel bed } \\
\text { (ft) }\end{array}$} & \multirow[b]{2}{*}{$\begin{array}{c}\text { Approximate } \\
\text { frontal slope } \\
\text { of scour hole } \\
\text { (ft/ft) }\end{array}$} \\
\hline & & Type & $\begin{array}{c}\text { Width } \\
\text { (ft) }\end{array}$ & $\begin{array}{l}\text { Penetration } \\
\text { into } \\
\text { bedrock } \\
\text { (ft) }\end{array}$ & $\begin{array}{l}\text { Seal course } \\
\text { bottom } \\
\text { elevation } \\
\text { (ft) }\end{array}$ & & & & & \\
\hline A1800 & 3 & Drilled shaft & 28 & 20 & 702.28 & 693 & 652 & 41 & 18 & 1.77 \\
\hline K0456 & 7 & Caisson & 18 & 2 & -- & 672 & 627 & 45 & 28 & 2.00 \\
\hline A0450 & 9 & Caisson & 22 & 5 & -- & 681 & 639 & 42 & 21 & a2.45 \\
\hline A4649 & 2 & Caisson & 24 & 1 & -- & 675 & 670 & 5 & 24 & 1.89 \\
\hline A4060 & 6 & Drilled shaft & 34 & 20 & 696.26 & 689 & 670 & 19 & ${ }^{\mathrm{b}} 6$ & $b_{--}$ \\
\hline A 4060 & 5 & Drilled shaft & 28 & 20 & 696.26 & 691 & 667 & 24 & 15 & 1.91 \\
\hline A5817 & 2 & Drilled shaft & 24 & 20 & 687.26 & 685 & 677 & 8 & 16 & 2.06 \\
\hline A0767 & 7 & Drilled shaft & 32 & 20 & 689.26 & 679 & 660 & 19 & 11 & 2.03 \\
\hline A4757 & $2 \mathrm{C}$ & Drilled shaft & 35 & 20 & 666.26 & 666 & 619 & 47 & 25 & 2.49 \\
\hline L0568 & 5 & Caisson & 20 & 2 & -- & 668 & 618 & 50 & 21 & $c_{--}$ \\
\hline
\end{tabular}

${ }^{a}$ Scour hole at this pier is substantially affected by upstream pier.

${ }^{b}$ Scour hole at this pier is substantially affected by upstream pier and apparent cobble-sized material on channel bed near the pier.

${ }^{\mathrm{c}} \mathrm{S}$ cour hole at this pier is substantially affected by upstream pier skewed to approach flow; unable to reasonably determine frontal slope. 


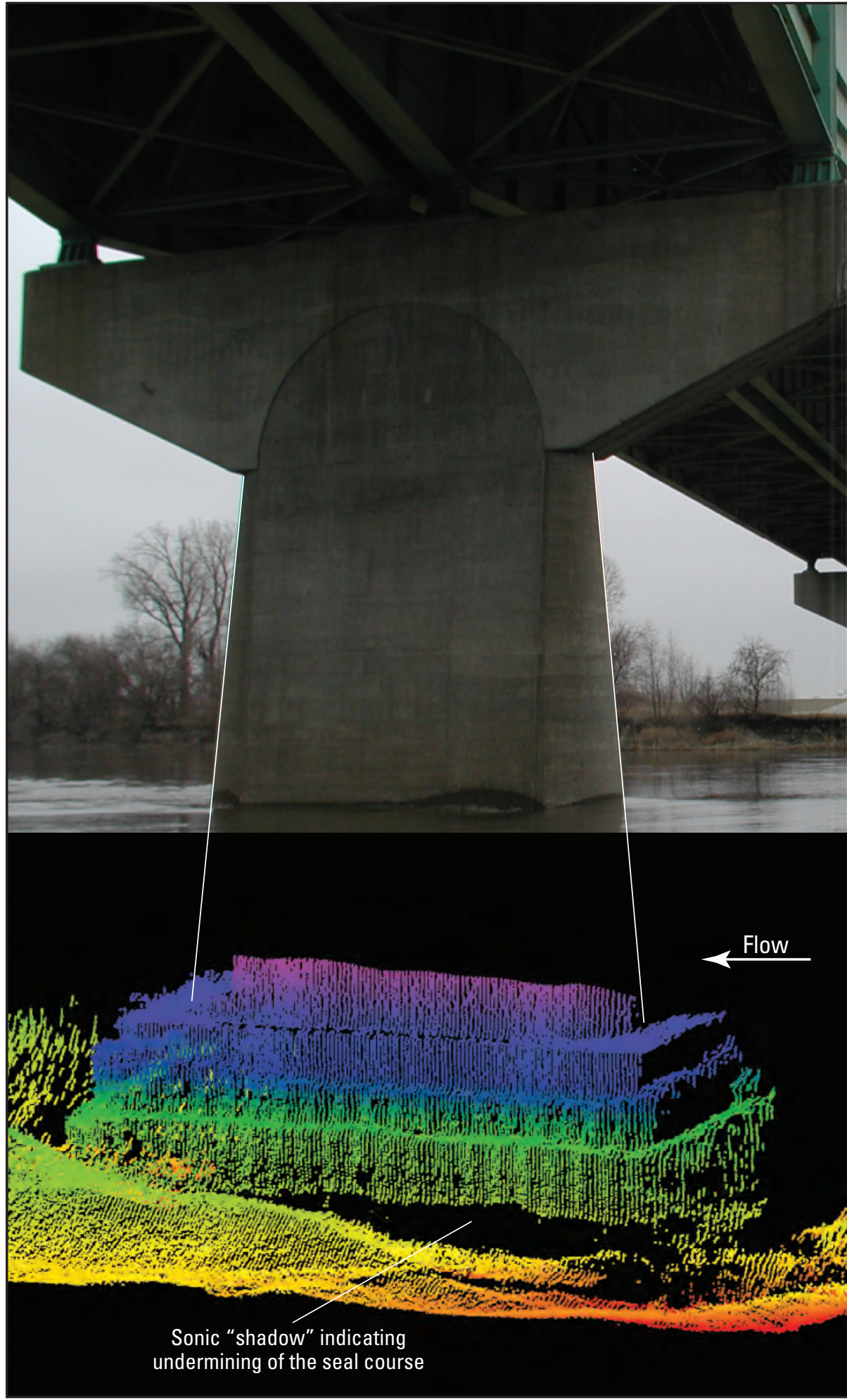

\section{EXPLANATION}

Elevation of point, in feet above the North American Vertical Datum of 1988

722
-720
-718
-716
-714
-712
-710
-708
-706
-704
-702
-700
-698
-696
-694
692

Photograph as shown is a reversal of actual photograph of the pier from the south side, and is shown for visualization purposes only.

Figure 11. Point cloud visualization of the channel bed and left (north) side of the main channel pier of structure A1800 on Interstate 635 over the Missouri River in Kansas City, Missouri. 


\section{Structures K0456 and A0450 on U.S. Highway 69}

Structures K0456 and A0450 are dual bridges on U.S. Highway 69 on the northwestern side of Kansas City, Missouri (figs. 1, 12). The survey was conducted on March 15,2010 , and the average water-surface elevation of the river in the survey area determined by the RTK GPS tide solution was $733.67 \mathrm{ft}$ (table 4). Flow on the Missouri River was about $129,000 \mathrm{ft}^{3} / \mathrm{s}$ during the survey (table 4 ).

The survey area was about 1,640 ft long and about $710 \mathrm{ft}$ wide, extending from bank to bank in the main channel (fig. 13). The upstream end of the survey area was about $640 \mathrm{ft}$ upstream from the centerline between structures K0456 and A0450

(figs. 12, 13). The channel-bed elevations ranged from about 688 to $720 \mathrm{ft}$ for most of the channel bed, except near the main channel piers. A broad, shallow thalweg along the outside of the river bend on the right (south) bank was about $5 \mathrm{ft}$ deeper than the channel bed in the middle of the channel (fig. 13). Between the rock spur dikes on the inside of the bend on the left (north) bank, deposits reached an elevation of about $722 \mathrm{ft}$ (fig. 13).
A localized deep hole was downstream from the upstream spur dike (fig. 13). Several large dune features were detected in the middle of the channel, as well as numerous smaller dunes and ripples throughout the channel, particularly downstream from the rock spur dikes and the main channel piers (fig. 13).

In the vicinity of the main channel pier of upstream structure K0456 (pier 7; fig. 14), a scour hole had a minimum elevation of about $672 \mathrm{ft}$ (table 4), about $28 \mathrm{ft}$ below the average channel bed immediately upstream from the pier. The scour hole upstream from pier 7 of upstream structure K0456 was about $9 \mathrm{ft}$ deeper than the scour hole upstream from pier 9 of downstream structure A0450 (table 5).

Information from bridge plans indicates that the main channel piers of both structures K0456 and A0450 are caissons on bedrock (figs. 15, 16). About $45 \mathrm{ft}$ of bed material was between the bottom of the deeper scour hole at structure K0456 and the bottom of the caissons (fig. 15; table 5). The surveyed channel bed was about $18 \mathrm{ft}$ deeper than the channel bed from the Level II scour survey in 2002 along the right (south) bank (figs. 15, 16).

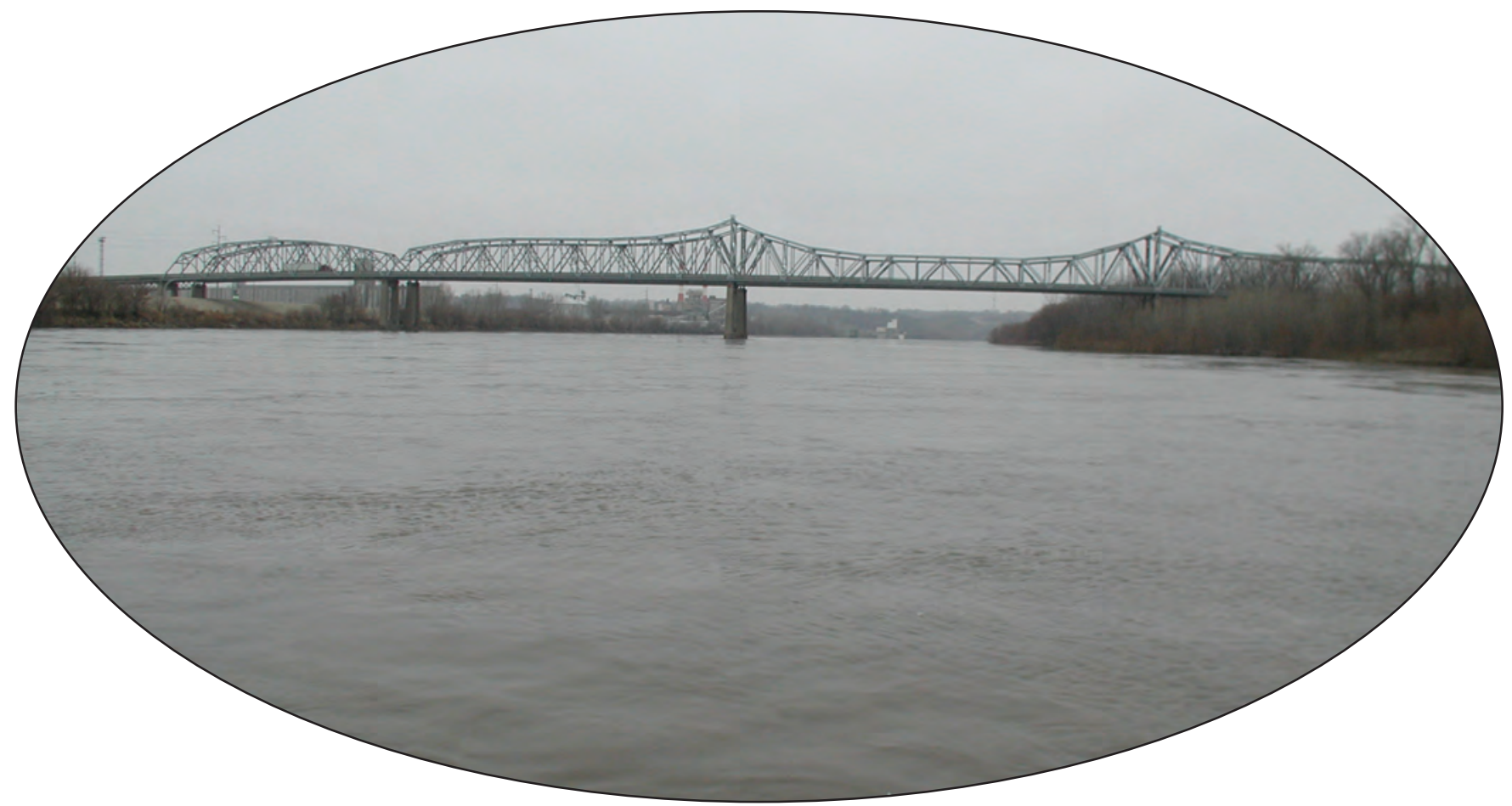

Structures K0456 and A0450 on U.S. Highway 69. Structure A0450 is in the foreground and K0456 is in the background. 


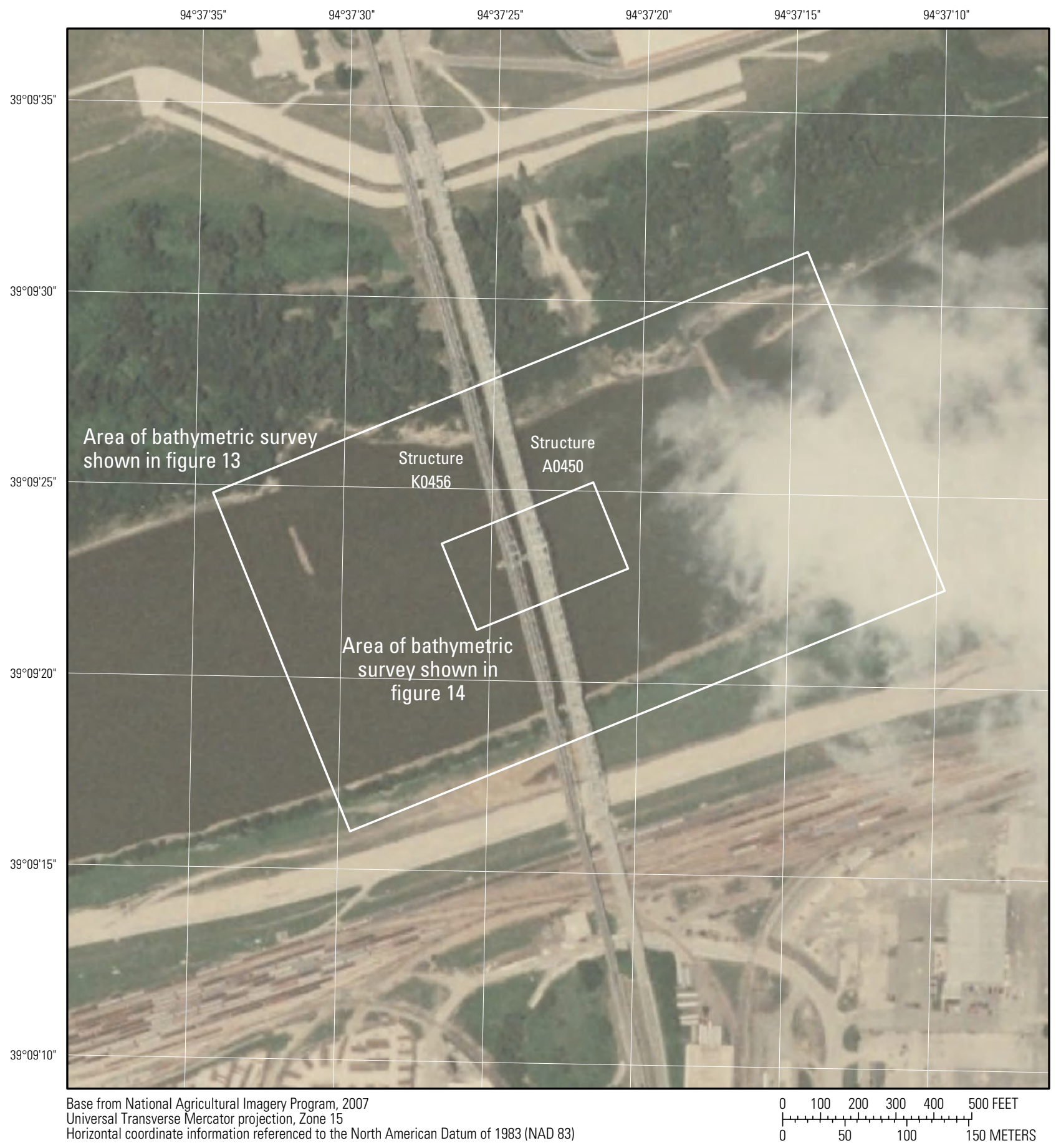

Figure 12. Location of the bathymetric survey area on the Missouri River near structures K0456 and A0450 on U.S. Highway 69 in Kansas City, Missouri. 


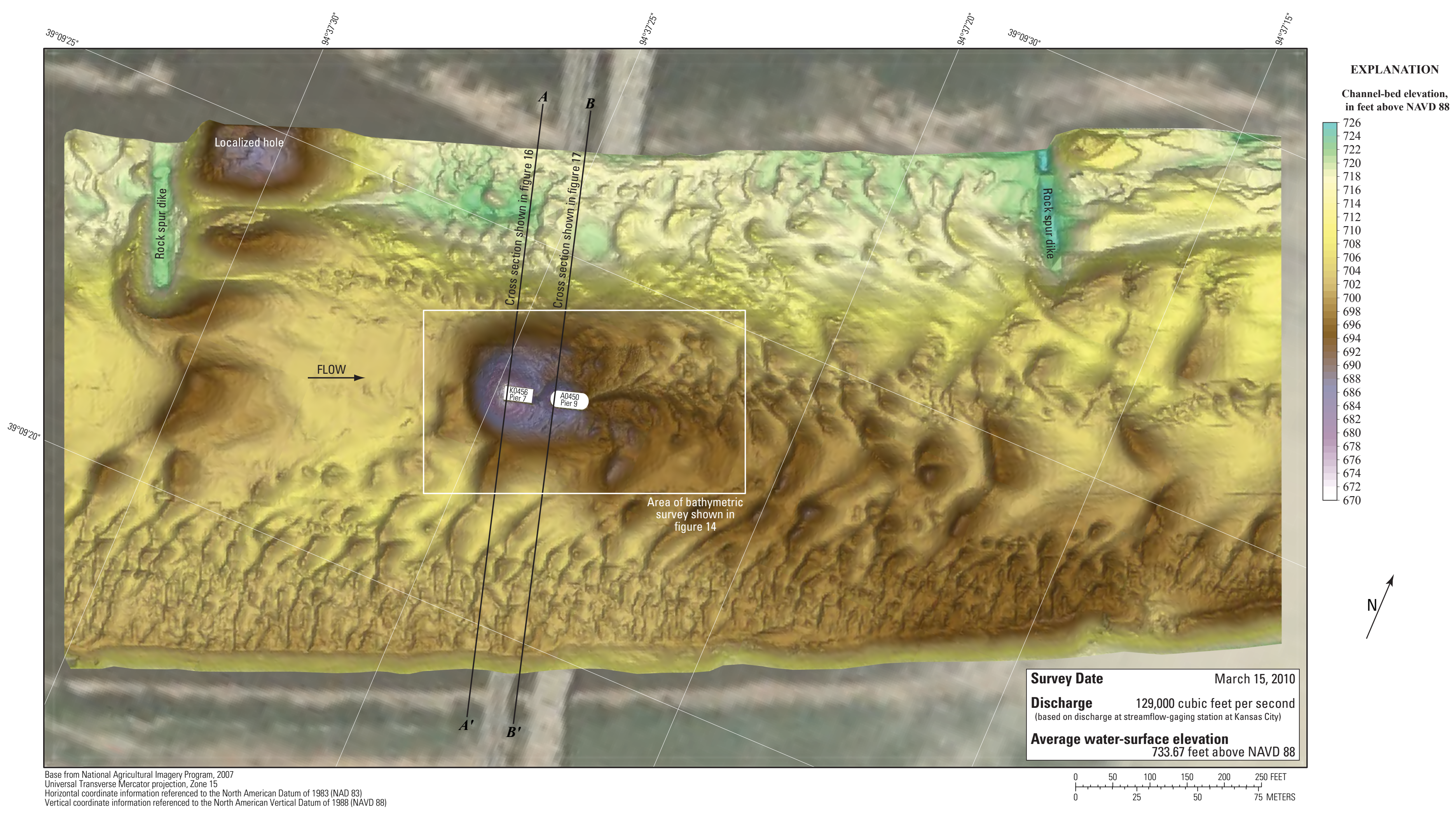

Figure 13. Bathymetric survey of the Missouri River channel in the vicinity of structures K0456 and A0450 on U.S. Highway 69 in Kansas City, Missouri. 


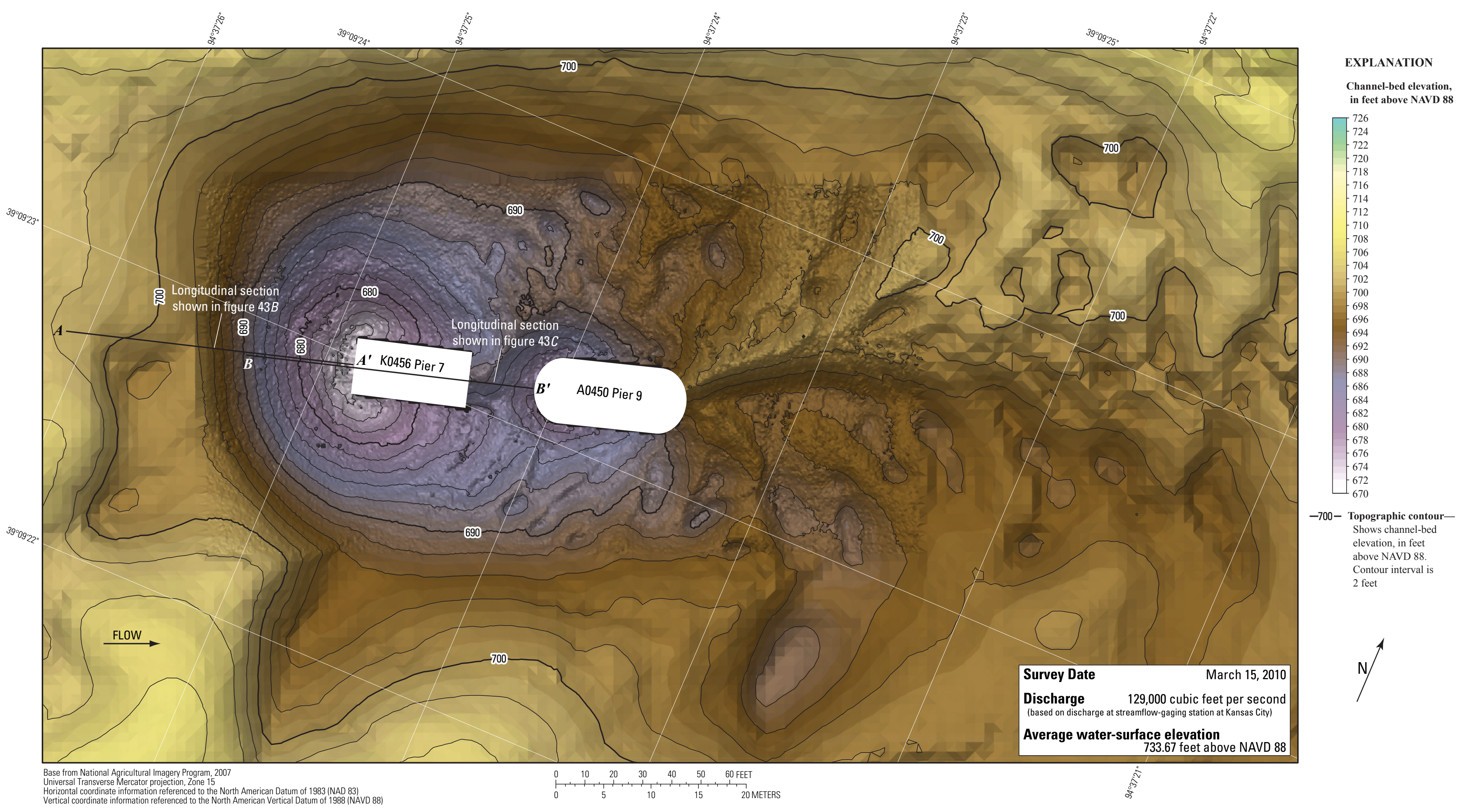

Figure 14. Bathymetric survey of the Missouri River channel in the vicinity of the main channel piers of structures K0456 and A0450 on U.S. Highway 69 in Kansas City, Missouri. 


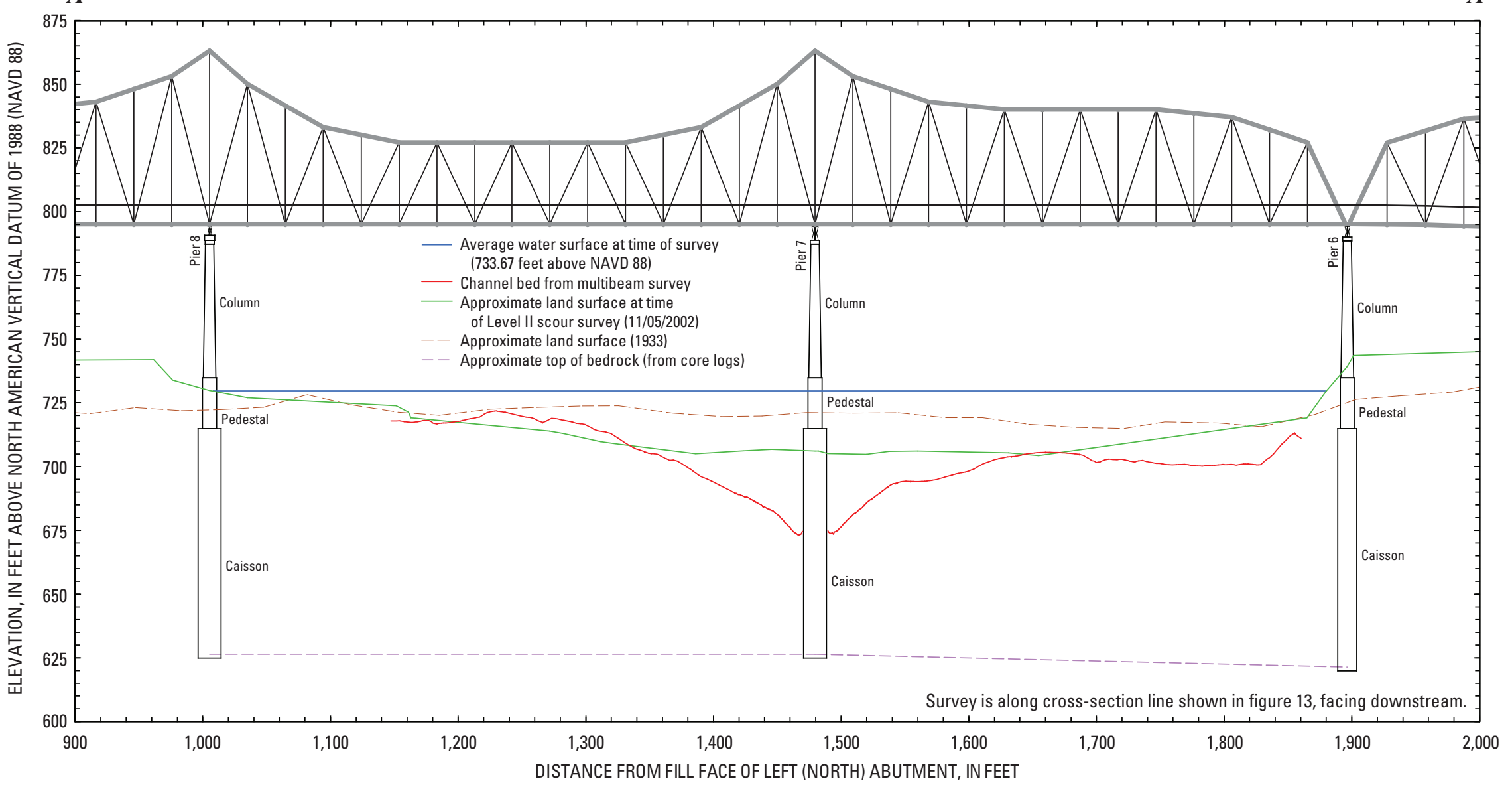

PART OF BRIDGE SHOWN ABOVE

if

Figure 15. Key features, substructural and superstructural details, and surveyed channel bed of structure K0456 on U.S. Highway 69 over the Missouri River in Kansas City, Missouri. 

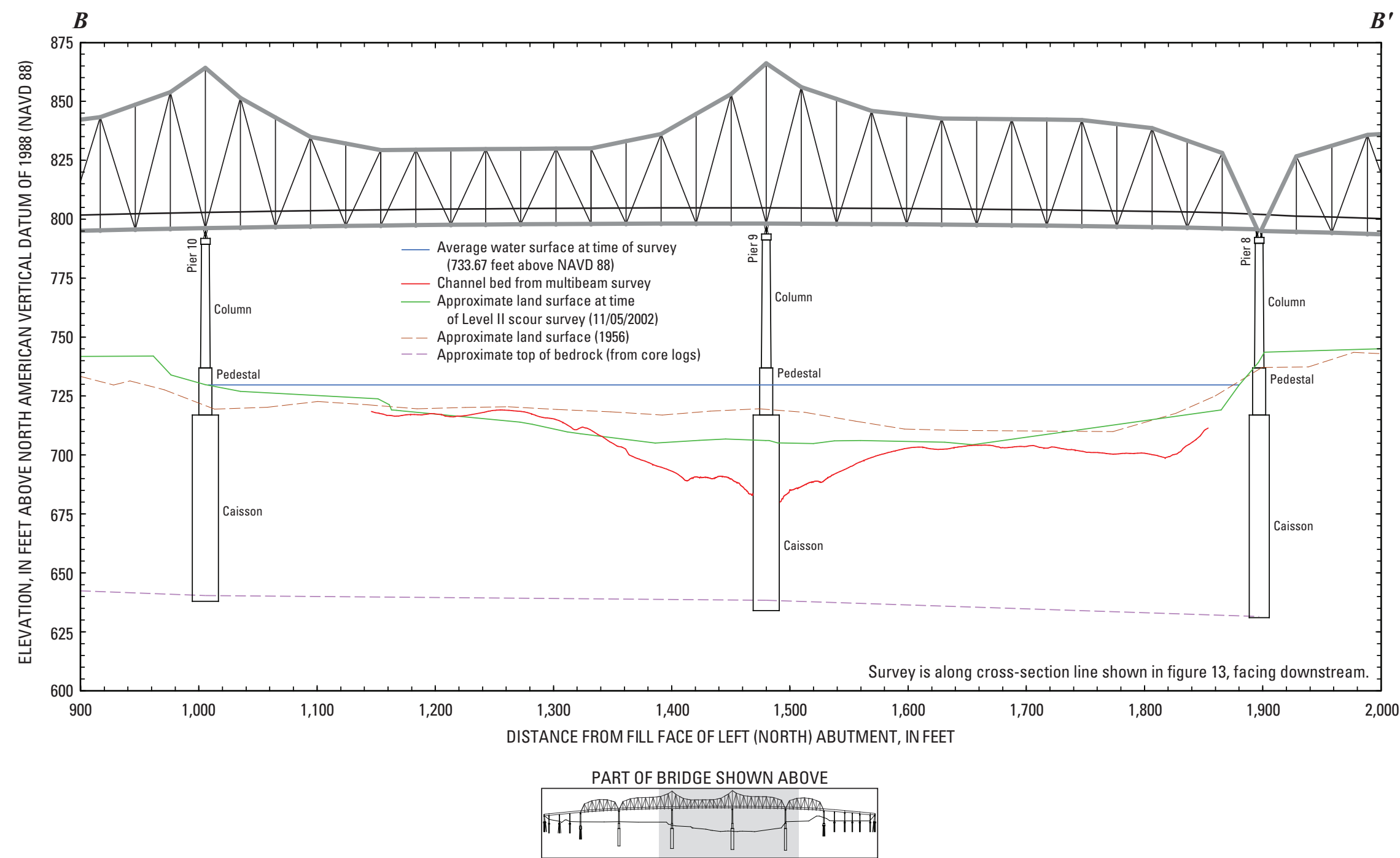

Figure 16. Key features, substructural and superstructural details, and surveyed channel bed of structure A0450 on U.S. Highway 69 over the Missouri River in Kansas City, Missouri. 


\section{Structure A4649 on U.S. Highway 169}

Structure A4649 is on U.S. Highway 169, immediately north of downtown Kansas City, Missouri (figs. 1, 17). The survey was conducted on March 16, 2010, and the average water-surface elevation of the river in the survey area determined by the RTK GPS tide solution was $727.85 \mathrm{ft}$ (table 4). Flow on the Missouri River was about $127,000 \mathrm{ft}^{3} / \mathrm{s}$ during the survey (table 4).

The survey area was about $1,800 \mathrm{ft}$ long and about $820 \mathrm{ft}$ wide, extending from bank to bank in the main channel (fig. 18). The upstream end of the survey area was about $820 \mathrm{ft}$ upstream from the centerline of structure A4649 at pier 2 (figs. 17, 18). The channel-bed elevations ranged from about 685 to $708 \mathrm{ft}$ for most of the channel bed, except near the main channel pier of structure A4649 and the various railroad bridge piers and concrete noses upstream from them (figs. 18, 19). A deep thalweg on the right (south) bank on the upstream end of the surveyed area was about $20 \mathrm{ft}$ deeper than the channel bed in the middle of the channel (fig. 18). The thalweg was shallower and shifted to the middle of the channel at the bridges and downstream (fig. 18). Upstream from the rock spur dike on the inside of the bend on the upstream left (north) bank, deposits reached an elevation of about $720 \mathrm{ft}$ (fig. 18). Remnants of piers from an old bridge (presumably the first Hannibal railroad bridge) were evident downstream from the existing Second Hannibal railroad bridge (fig. 18). Unlike the two upstream sites (structure A1800 and structures K0456 and A0450), large dune features were not detected in the channel at this site; however, numerous medium and small dunes and ripples were detected throughout the channel, particularly in the channel thalweg upstream and downstream from structure A4649 and between the highway bridge and the railroad bridge (fig. 18).

In the vicinity of the main channel pier (pier 2; fig. 19), a scour hole had a minimum elevation of about $675 \mathrm{ft}$ (table 4), about $24 \mathrm{ft}$ below the average channel bed immediately upstream from the pier (table 5). The scour hole was about $2 \mathrm{ft}$ deeper on the right (south) side than the north side, and the hole extended further around on the right side (fig. 19). A submerged remnant of a structure near the left downstream side of the pier (fig. 19) was presumably a nose for the railroad bridge downstream similar to the concrete nose upstream from the railroad bridge turntable pier. The remnants of the old bridge piers were clearly defined, as were the piles of cobble-size debris around them. The remnant downstream from the existing railroad bridge turntable pier had a maximum elevation of over $710 \mathrm{ft}$ (fig. 19), which was only $17 \mathrm{ft}$ below the water surface on the day of the survey. Avoiding this pier remnant would be difficult in lower flow conditions than those on the day of the survey.

Information from bridge plans indicate that the main channel pier structure A4649 is a caisson on bedrock, but only about $5 \mathrm{ft}$ of bed material was between the bottom of the scour hole and the bottom of the caissons (fig. 20; table 5). The surveyed channel bed was approximately the same as the channel bed from the Level II scour survey in 2002 near the thalweg on the right (south) side of the channel, but was about $25 \mathrm{ft}$ deeper in mid-channel (fig. 20).

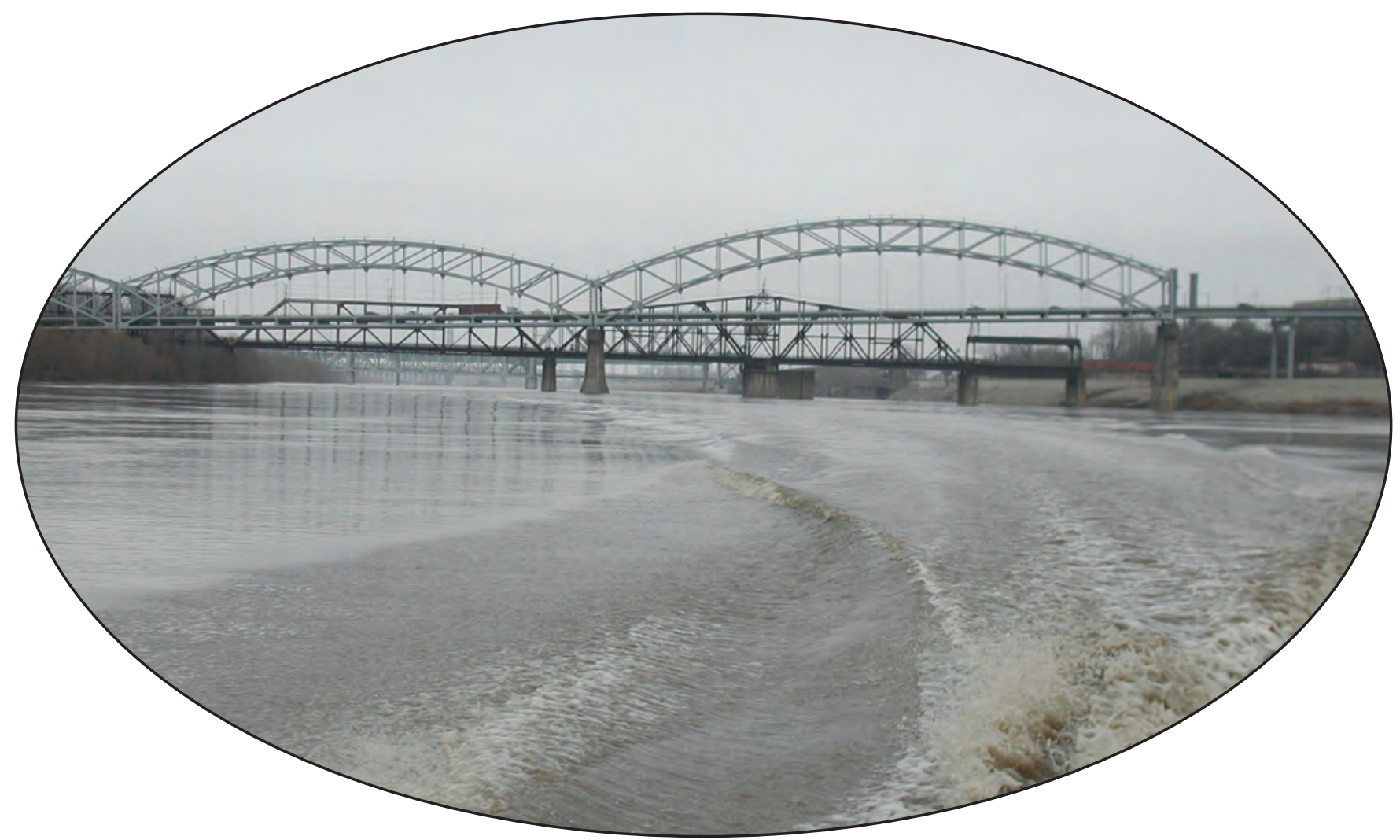

Structure A4649 on U.S. Highway 169. 


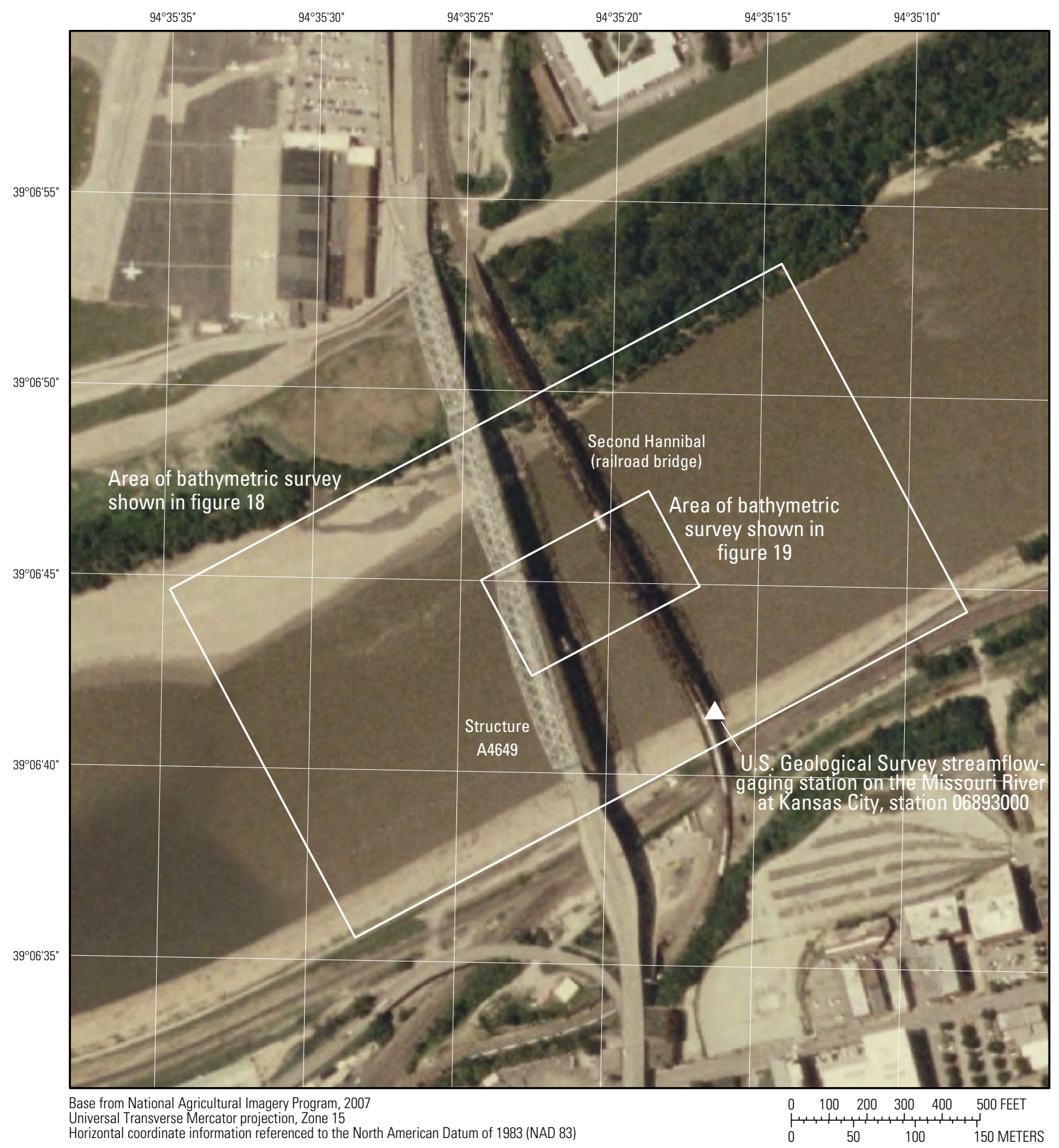

Figure 17. Location of the bathymetric survey area on the Missouri River near structure A4649 on U.S. Highway 169 in Kansas City, Missouri. 


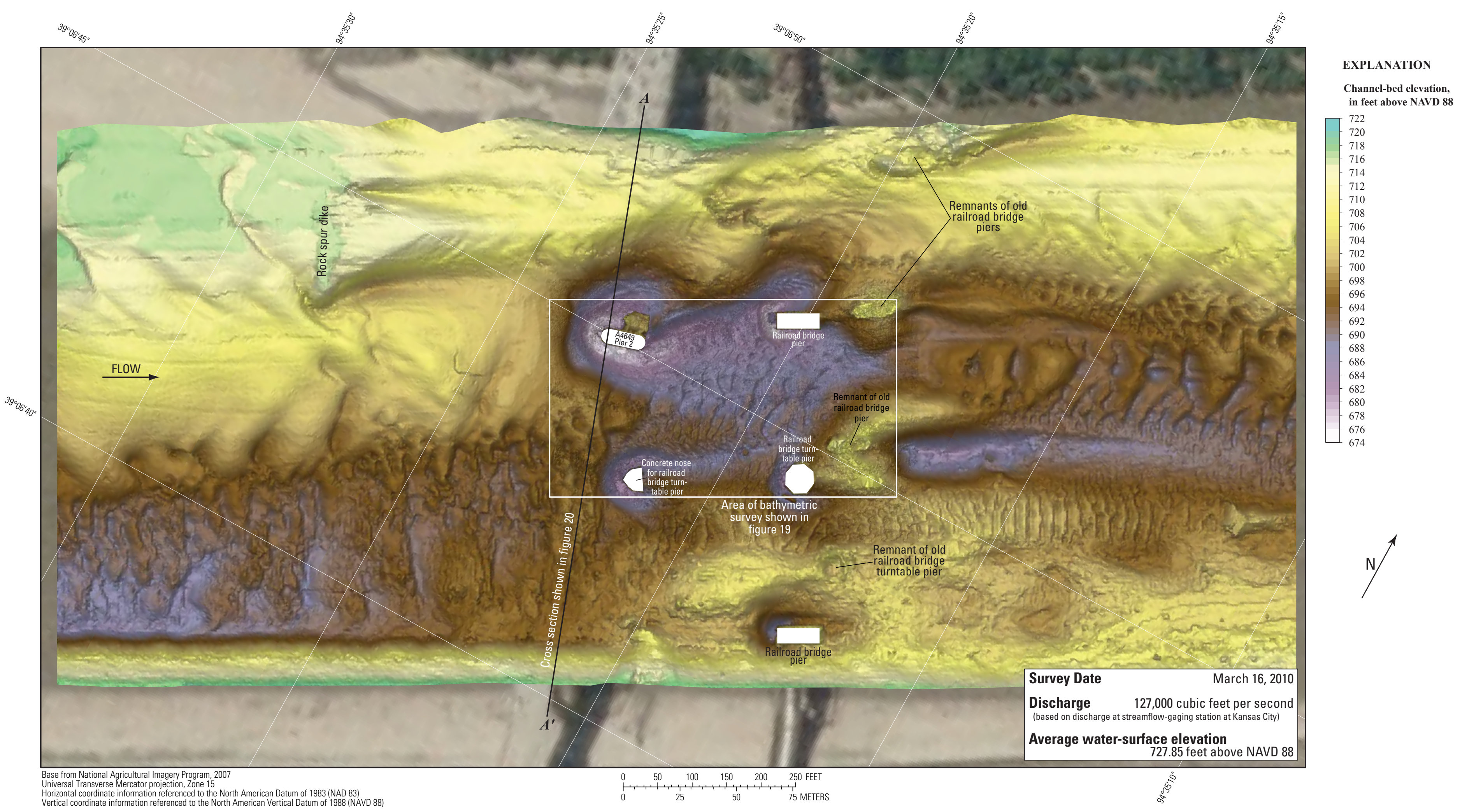

Figure 18. Bathymetric survey of the Missouri River channel in the vicinity of structure A4649 on U.S. Highway 169 in Kansas City, Missouri. 


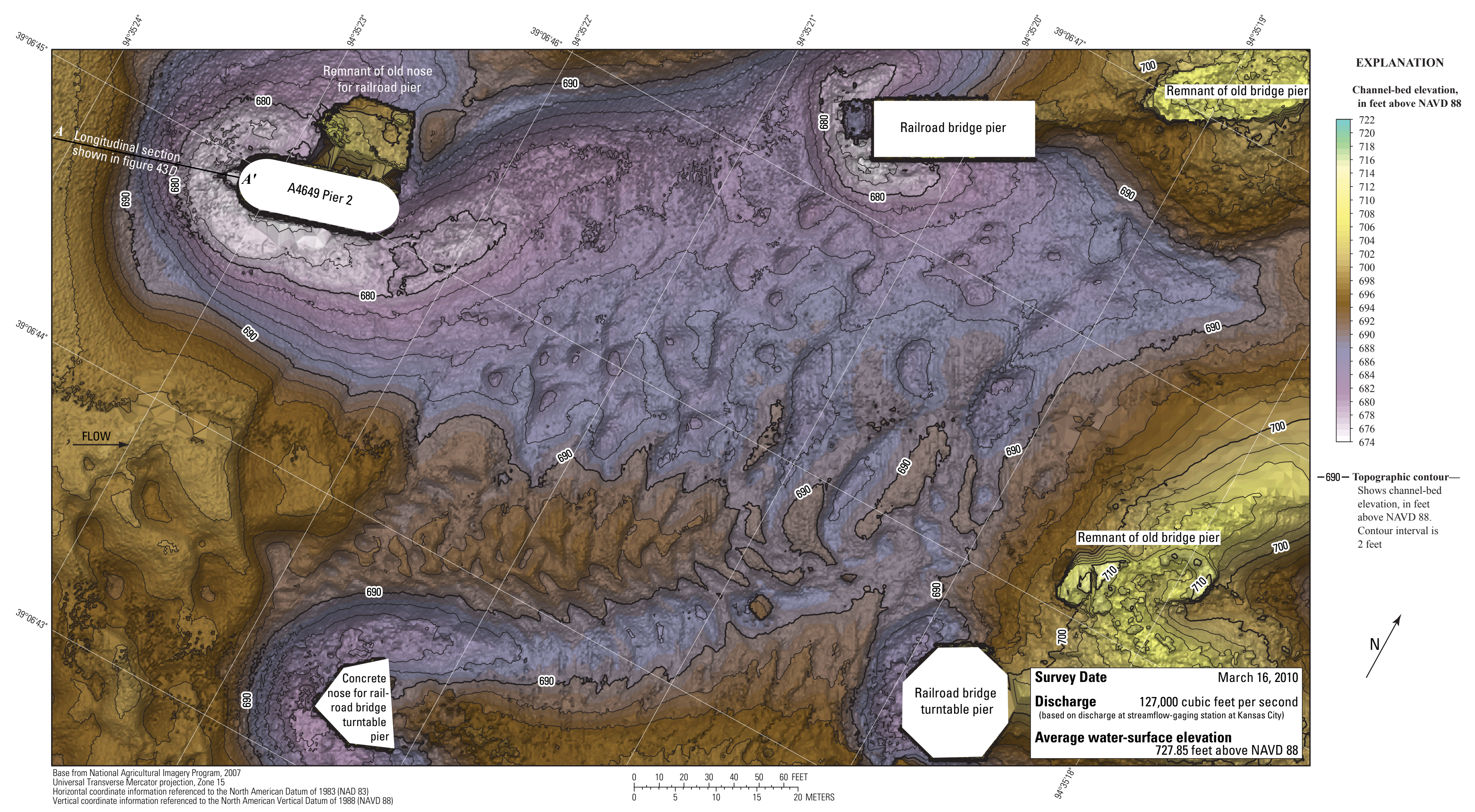

Figure 19. Bathymetric survey of the Missouri River channel in the vicinity of the main channel pier of structure A4649 on U.S. Highway 169 in Kansas City, Missouri. 

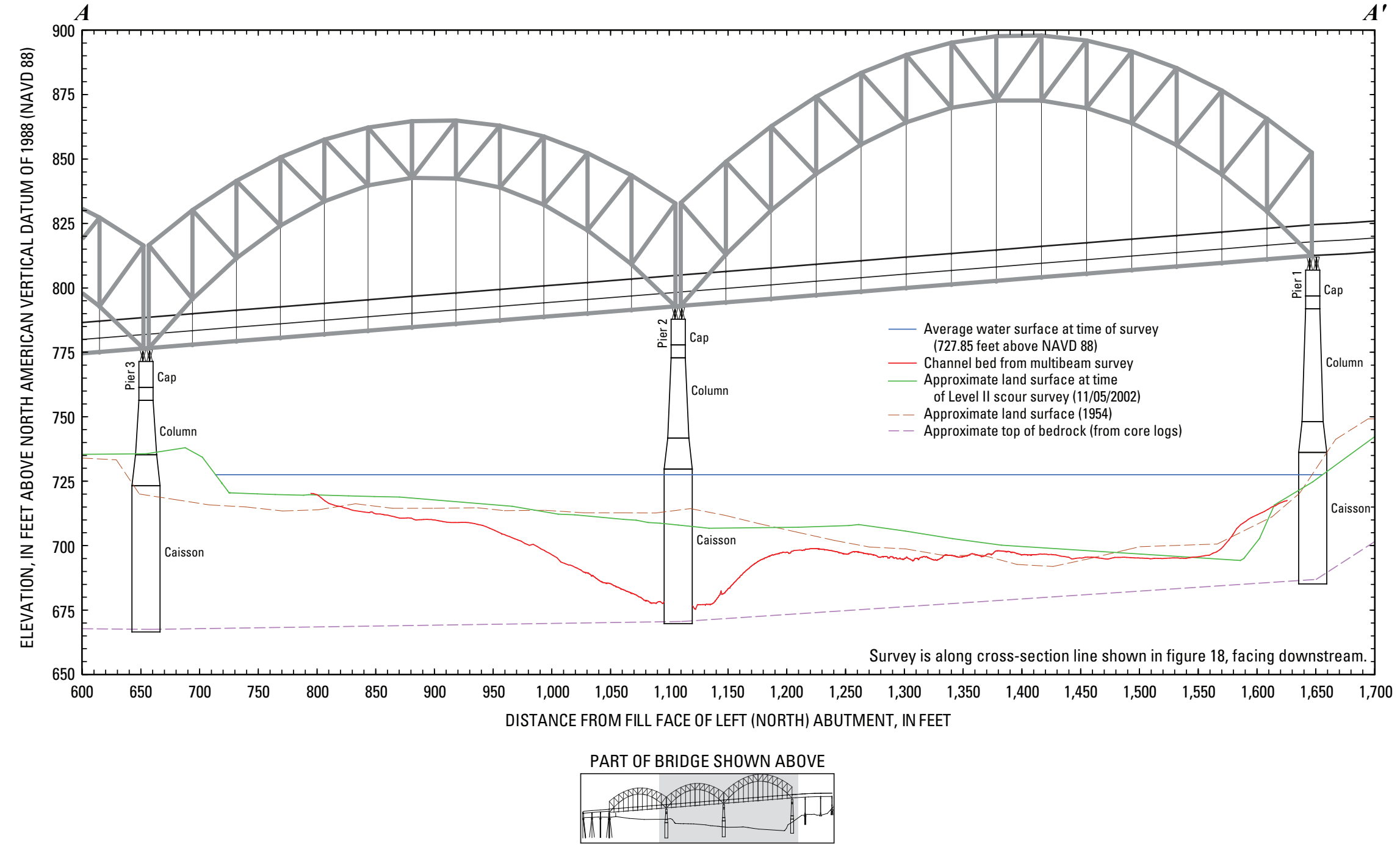

Figure 20. Key features, substructural and superstructural details, and surveyed channel bed of structure A4649 on U.S. Highway 169 over the Missouri River in Kansas City, Missouri. 


\section{Structure A4060 on State Highway 9}

Structure A4060 is on State Highway 9, immediately north of downtown Kansas City, Missouri (figs. 1, 21). The survey was conducted on March 16, 2010, and the average water-surface elevation of the river in the survey area determined by the RTK GPS tide solution was $727.05 \mathrm{ft}$ (table 4). Flow on the Missouri River was about 126,000 $\mathrm{ft}^{3} / \mathrm{s}$ during the survey (table 4).

The survey area was about $1,800 \mathrm{ft}$ long and about $810 \mathrm{ft}$ wide, extending from bank to bank in the main channel (fig. 22). Piers 5 and 6 were in the water and away from the banks at structure A4060. The upstream end of the survey area was about $860 \mathrm{ft}$ upstream from the centerline of structure A4060 at pier 6 (figs. 21, 22). The channel-bed elevations ranged from about 688 to $710 \mathrm{ft}$ for most of the channel bed, except near the railroad bridge pier upstream from pier 6 of structure A4060. A deep thalweg along the right (south) bank throughout the surveyed area was about $20 \mathrm{ft}$ deeper than the channel bed in the middle of the channel (fig. 22). A few large dune features were detected in the middle of the channel upstream from the bridges, as well as numerous smaller dunes and ripples along the left (north) bank and in the channel thalweg on the right (south) side (fig. 22). Upstream from the rock spur dike on the upstream left (north) bank, deposits reached an elevation of about $714 \mathrm{ft}$ (fig. 22). Downstream from structure A4060, the elevations in the middle of the channel were 5 to $8 \mathrm{ft}$ lower than elevations upstream from the bridges.

Near the right main channel pier (pier 6; fig. 23), a poorly defined scour hole had a minimum elevation of about $689 \mathrm{ft}$; however, a substantial scour hole immediately upstream from the pier had a minimum elevation of about $679 \mathrm{ft}$. This deeper hole appeared to be the result of flow over large sheet piling panels that were lying on the channel bottom on the right (south) side of the upstream railroad bridge pier (fig. 23).
A pile of cobble-sized material immediately upstream from pier 6 of structure A4060 appeared to extend around the right (south) side (fig. 23), but it was about $1 \mathrm{ft}$ below the elevation of the bottom of the pier seal course of $696.26 \mathrm{ft}$ (fig. 24; table 5). The minimum elevation in the vicinity of pier 6 was about $7 \mathrm{ft}$ below the elevation of the bottom of the pier seal course (figs. 23, 24; table 5). Information from bridge plans indicates that pier 6 is founded on shafts drilled $20 \mathrm{ft}$ into bedrock, with about $19 \mathrm{ft}$ of bed material between the bottom of the scour hole and bedrock (fig. 24; table 5). A point cloud visualization of the multibeam depth points obtained during the survey indicates the bottom of the seal course as a sonic "shadow" (fig. 25).

In the immediate vicinity of the left main channel pier (pier 5; fig. 26), a scour hole had a minimum elevation of about $691 \mathrm{ft}$ (table 4), about $5 \mathrm{ft}$ below the elevation of the bottom of the pier seal course of $696.26 \mathrm{ft}$ (fig. 24; table 5). Information from bridge plans indicates that pier 5 also is founded on shafts drilled $20 \mathrm{ft}$ into bedrock, with about $24 \mathrm{ft}$ of bed material between the bottom of the scour hole and bedrock (fig. 24; table 5). The point cloud visualization of the multibeam depth points obtained during the survey does not clearly indicate the bottom of the seal course as a sonic "shadow" because the side of the seal course did not have as many return pings, resulting in poor point coverage. However, the difference in elevation between the top of the seal course and bed can be seen, and is greater than the depth of the seal course (fig. 27). Several beams or piles protruded from the channel bed immediately upstream from pier 5 (fig. 26).

The surveyed channel bed was about the same as the channel bed from the Level II scour survey in 2002 on the left (north) side and middle of the channel except near pier 5 (fig. 24). Near the thalweg on the right (south) side of the channel, the surveyed channel was about $15 \mathrm{ft}$ deeper than during the Level II scour survey in 2002, but was similar to the channel configuration from 1981 (fig. 24).

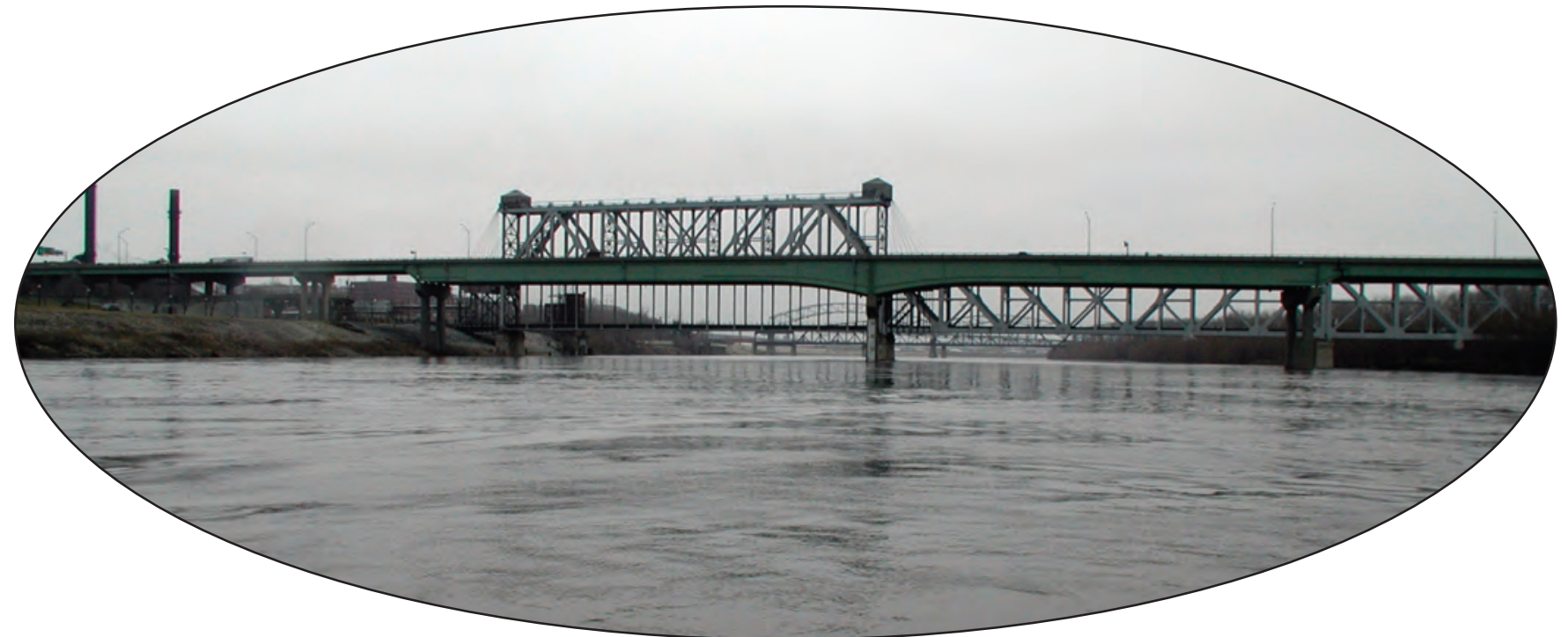

Structure A4060 on State Highway 9. 


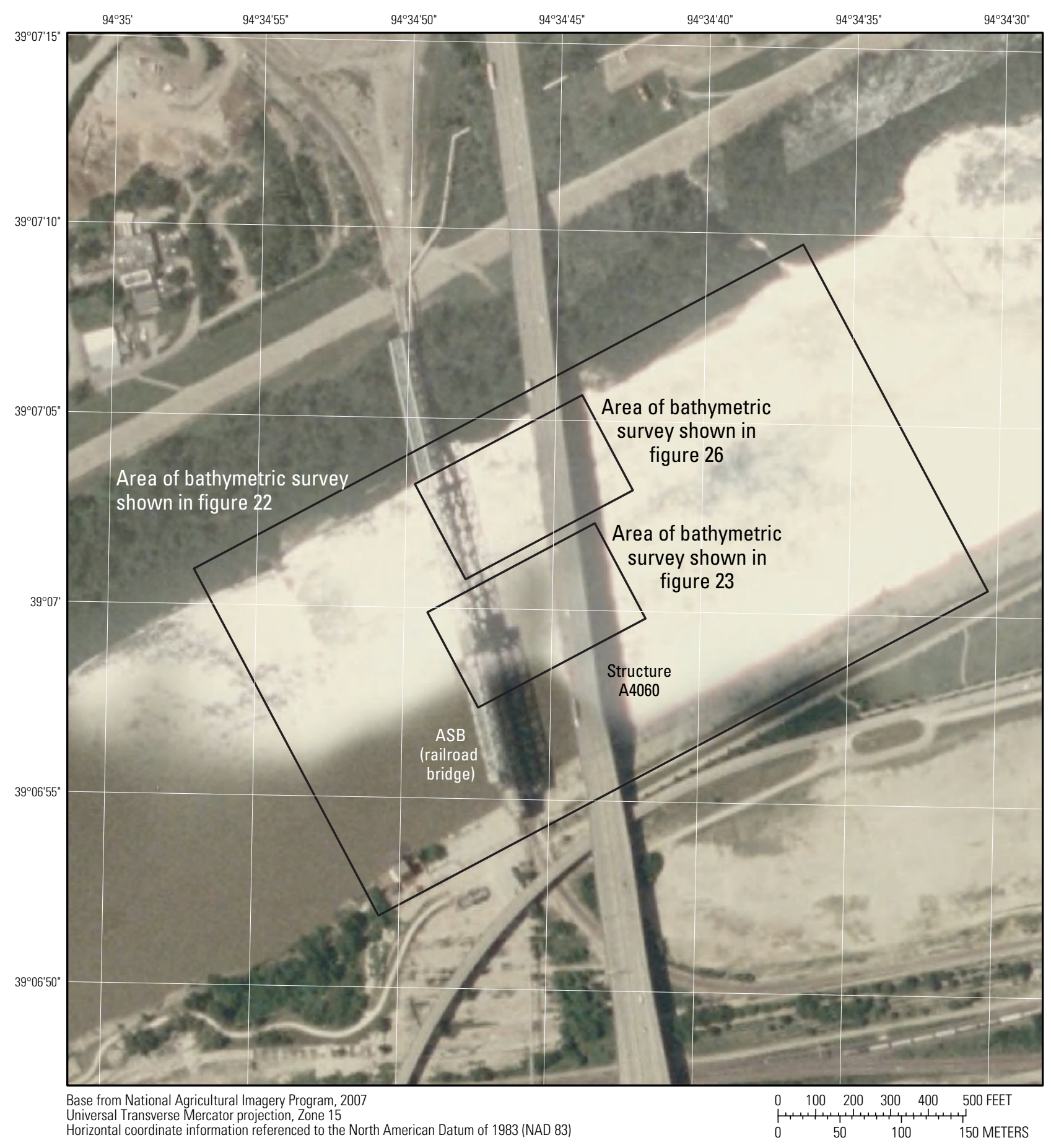

Figure 21. Location of the bathymetric survey area on the Missouri River near structure A4060 on State Highway 9 in Kansas City, Missouri. 


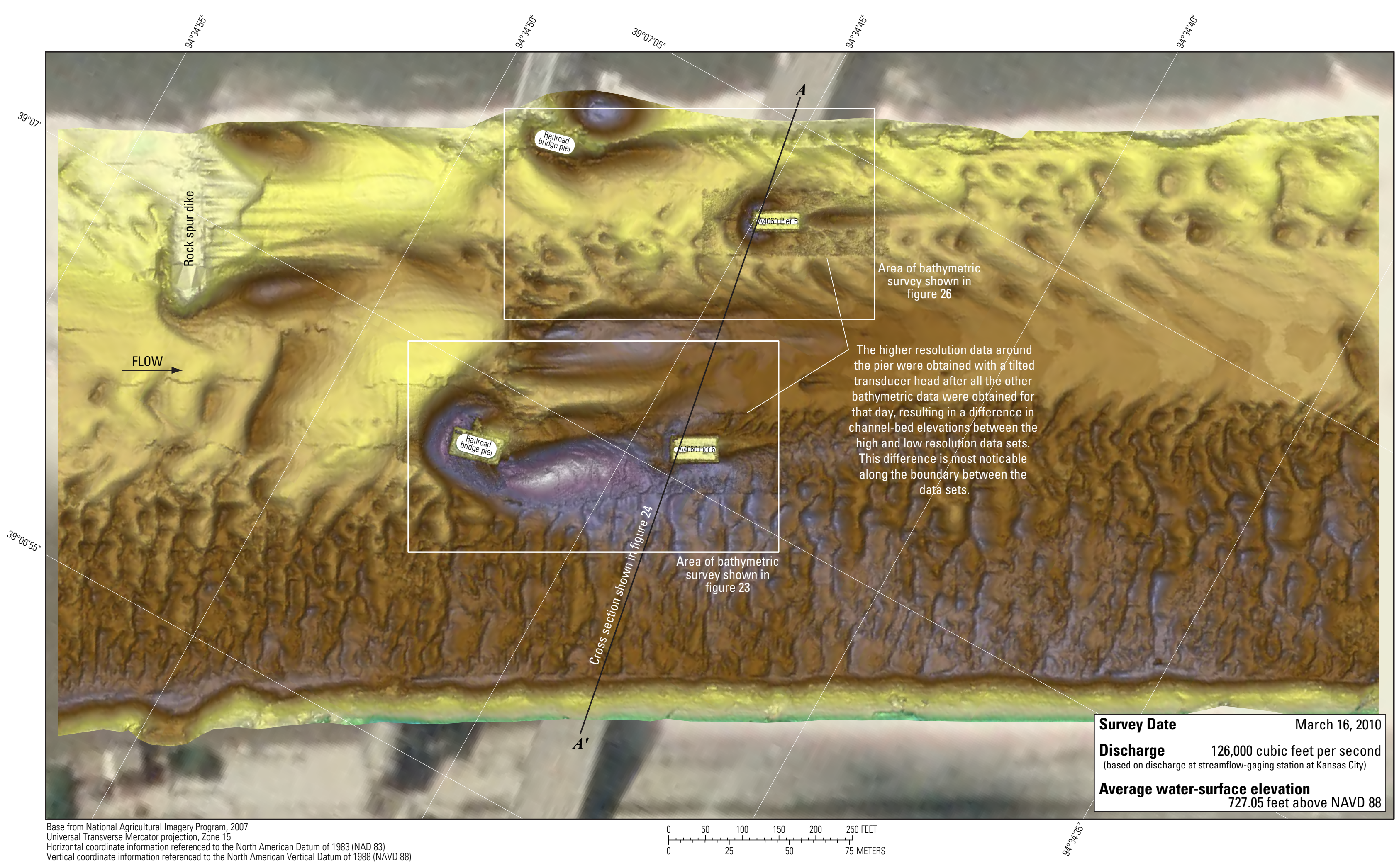

EXPLANATION

Channel-bed elevation,

720
718
716

-714
-712
-710

-712
-710
-708

-706
-704
-702

-702
-700
-698

-698
-696
-694
692

-692
-690
-688

-688
-686
-684
-682

${ }_{680}^{682}$

Figure 22. Bathymetric survey of the Missouri River channel in the vicinity of structure A4060 on State Highway 9 in Kansas City, Missouri. 


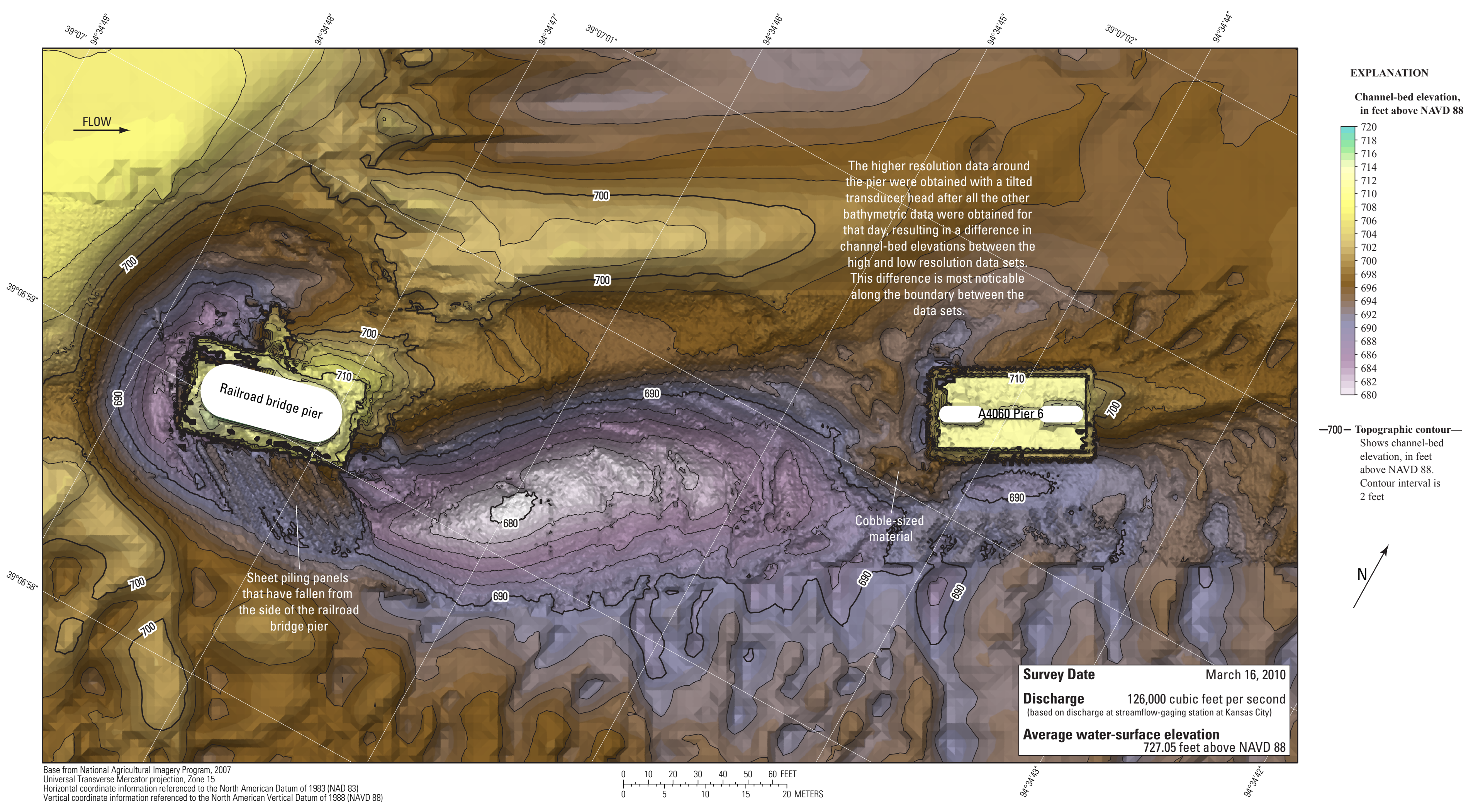

Figure 23. Bathymetric survey of the Missouri River channel in the vicinity of the right main channel pier of structure A4060 on State Highway 9 in Kansas City, Missouri. 


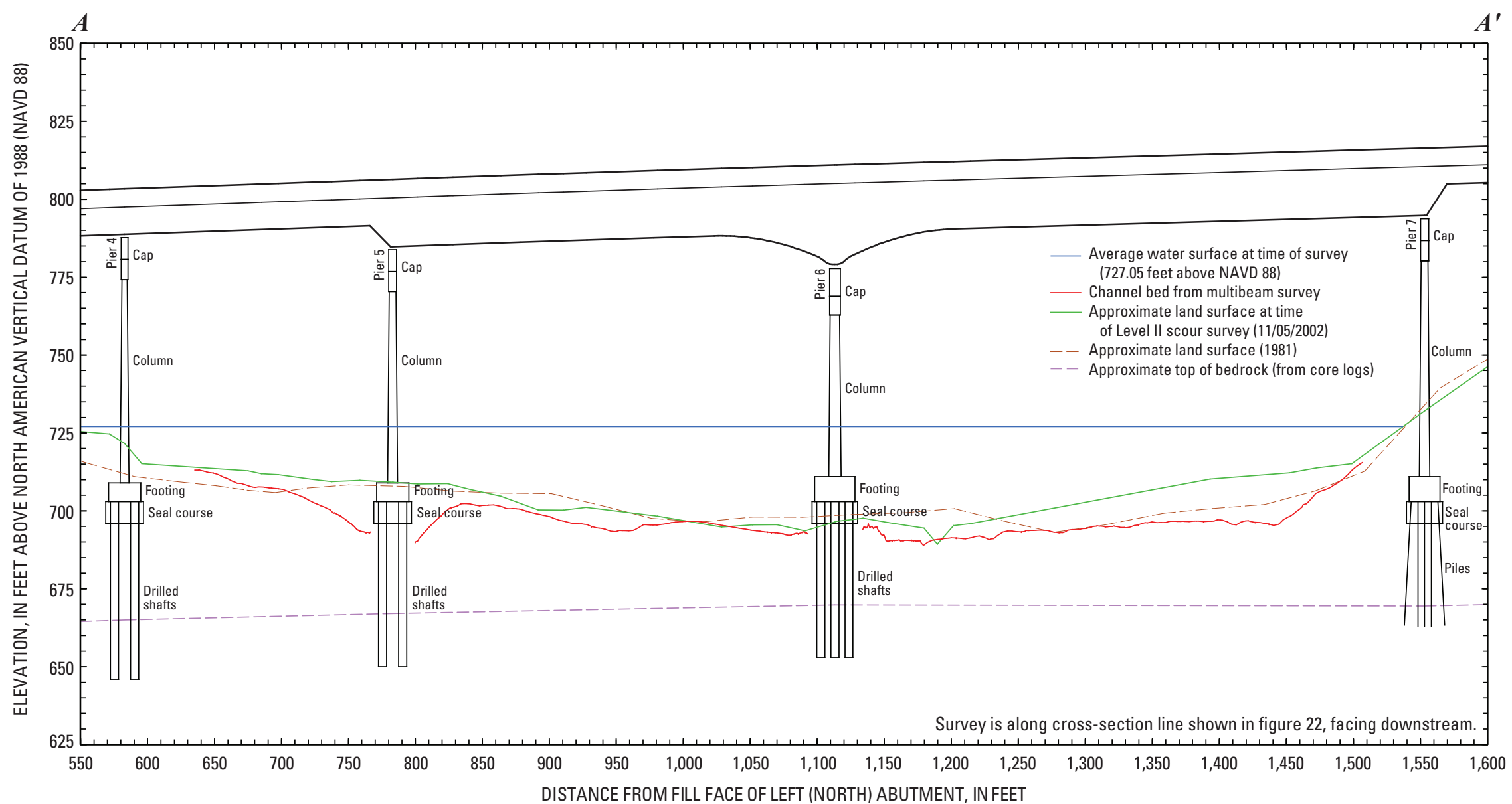

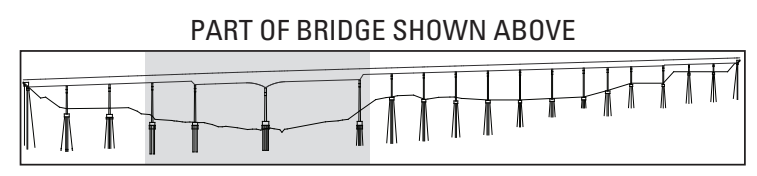

Figure 24. Key features, substructural and superstructural details, and surveyed channel bed of structure A4060 on State Highway 9 over the Missouri River in Kansas City, Missouri. 


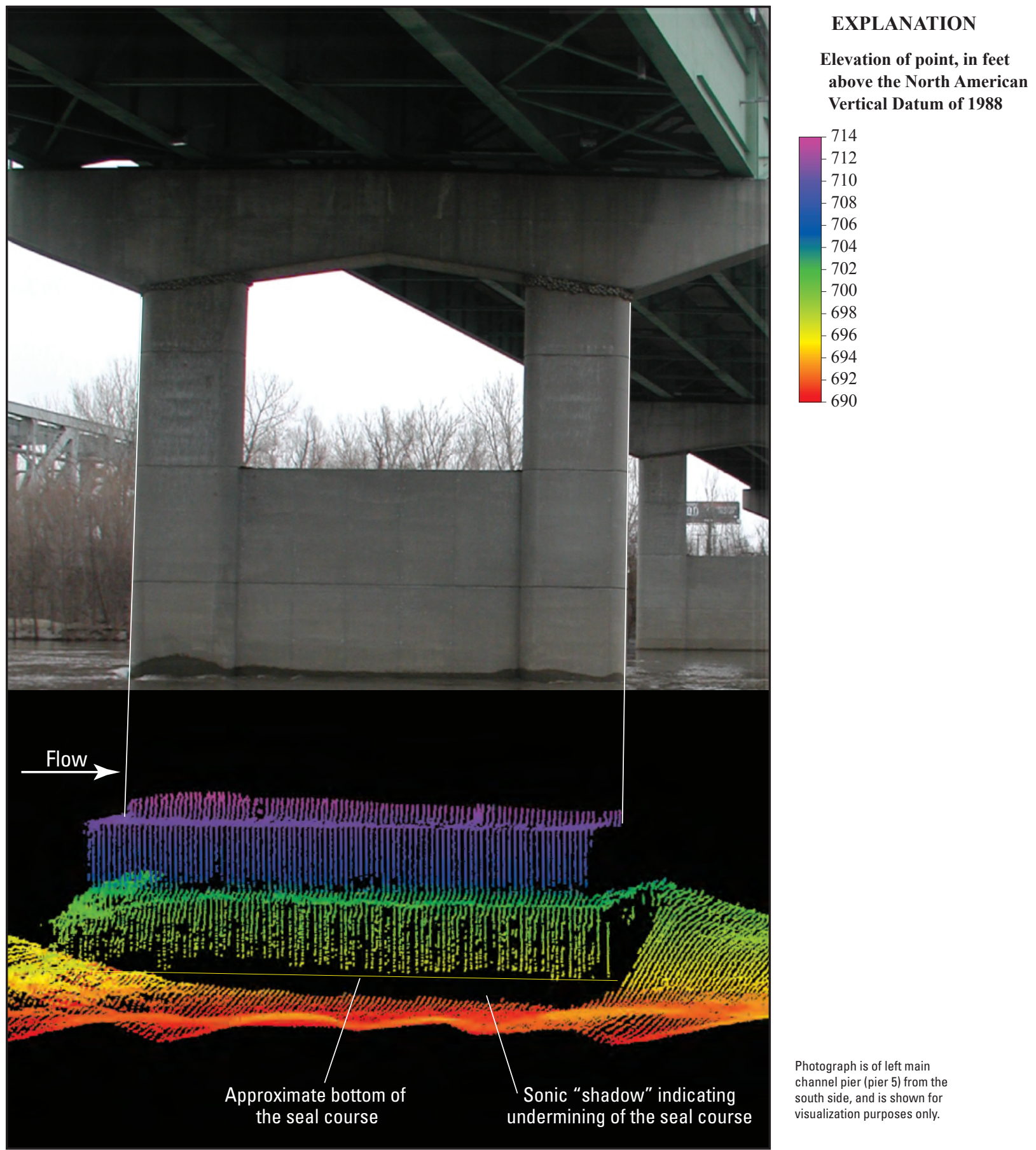

Figure 25. Point cloud visualization of the channel bed and right (south) side of the right main channel pier (pier 6) of structure A4060 on State Highway 9 over the Missouri River in Kansas City, Missouri. 


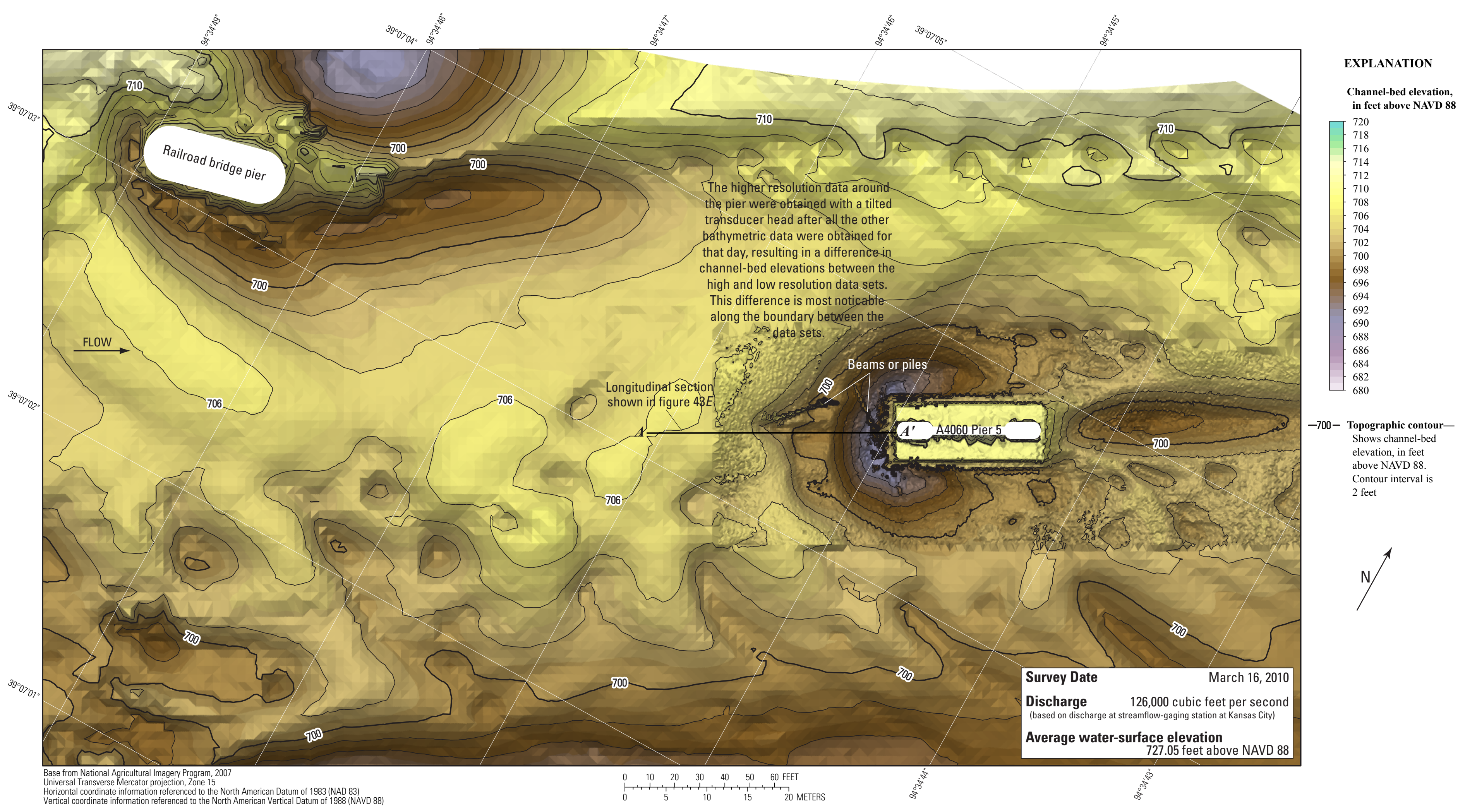

Figure 26. Bathymetric survey of the Missouri River channel in the vicinity of the left main channel pier of structure A4060 on State Highway 9 in Kansas City, Missouri. 


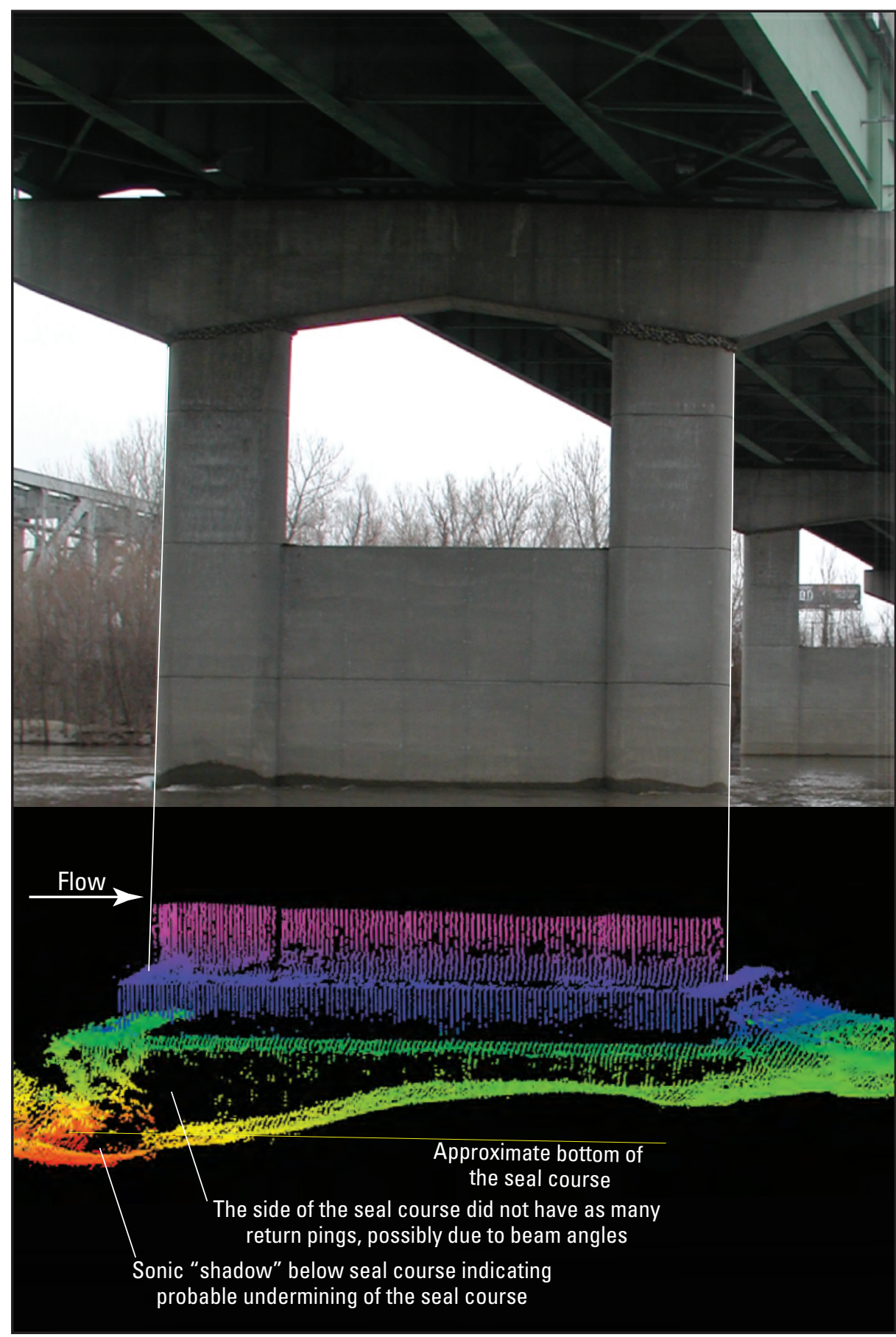

\section{EXPLANATION}

Elevation of point, in feet above the North American Vertical Datum of 1988

714
-712
-710
-708
-706
-704
-702
-700
-698
-696
-694
-692
-690

Figure 27. Point cloud visualization of the channel bed and right (south) side of the left main channel pier (pier 5) of structure A4060 on State Highway 9 over the Missouri River in Kansas City, Missouri. 


\section{Structure A5817 on State Highway 269}

Structure A5817 is on State Highway 269, northeast of downtown Kansas City, Missouri (figs. 1, 28). The survey was conducted on March 17, 2010, and the average watersurface elevation of the river in the survey area determined by the RTK GPS tide solution was $724.05 \mathrm{ft}$ (table 4). Flow on the Missouri River was about $124,000 \mathrm{ft}^{3} / \mathrm{s}$ during the survey (table 4).

The survey area was about $1,800 \mathrm{ft}$ long and about $920 \mathrm{ft}$ wide, extending from bank to bank in the main channel (fig. 29). Piers 2 and 3 were in the water and away from the banks at structure A5817; however, pier 3 was in shallow water, and only limited bathymetric data could be obtained near it. The upstream end of the survey area was about $810 \mathrm{ft}$ upstream from the centerline of structure A5817 at pier 2 (figs. 28, 29). The channel-bed elevations ranged from about 679 to $708 \mathrm{ft}$, except near the rock spur dike on the upstream right (south) bank and near pier 3 (fig. 29). A deep thalweg along the left (north) bank throughout the surveyed area contained evidence of bedrock exposure, and was about $25 \mathrm{ft}$ deeper than the channel bed in the middle of the channel (fig. 29). Numerous medium to large dune features were detected throughout the middle of the channel, as well as numerous smaller dunes and ripples along the right (south) bank (fig. 29); the lack of dunes in the thalweg near structure A5817 compared to those seen at several of the upstream bridge sites further substantiates the presence of rock outcrops in the thalweg near structure A5817. Two piles of coarse material downstream from structure A5817 appeared to be remnants of old piers.

In the vicinity of the main channel pier 2 (fig. 30), a scour hole had a minimum elevation of about $685 \mathrm{ft}$ (table 4), about $1 \mathrm{ft}$ below the elevation of the bottom of the pier seal course of $687.26 \mathrm{ft}$ (fig. 31; table 5). Information from bridge plans indicates that pier 2 of structure A5817 is founded on shafts drilled $20 \mathrm{ft}$ into bedrock, with about $8 \mathrm{ft}$ of bed material between the bottom of the scour hole and bedrock (fig. 31; table 5). A point cloud visualization of the multibeam depth points obtained during the survey shows the potential minor undermining as a sonic "shadow" when the bottom of the seal course is shown (fig. 32).

The surveyed channel bed was about 8 to $10 \mathrm{ft}$ lower than the channel configuration from 1992 (fig. 31). The approximate top of bedrock line from bridge plans further substantiates the likelihood of the channel thalweg having penetrated the fluvial material to bedrock (fig. 31).

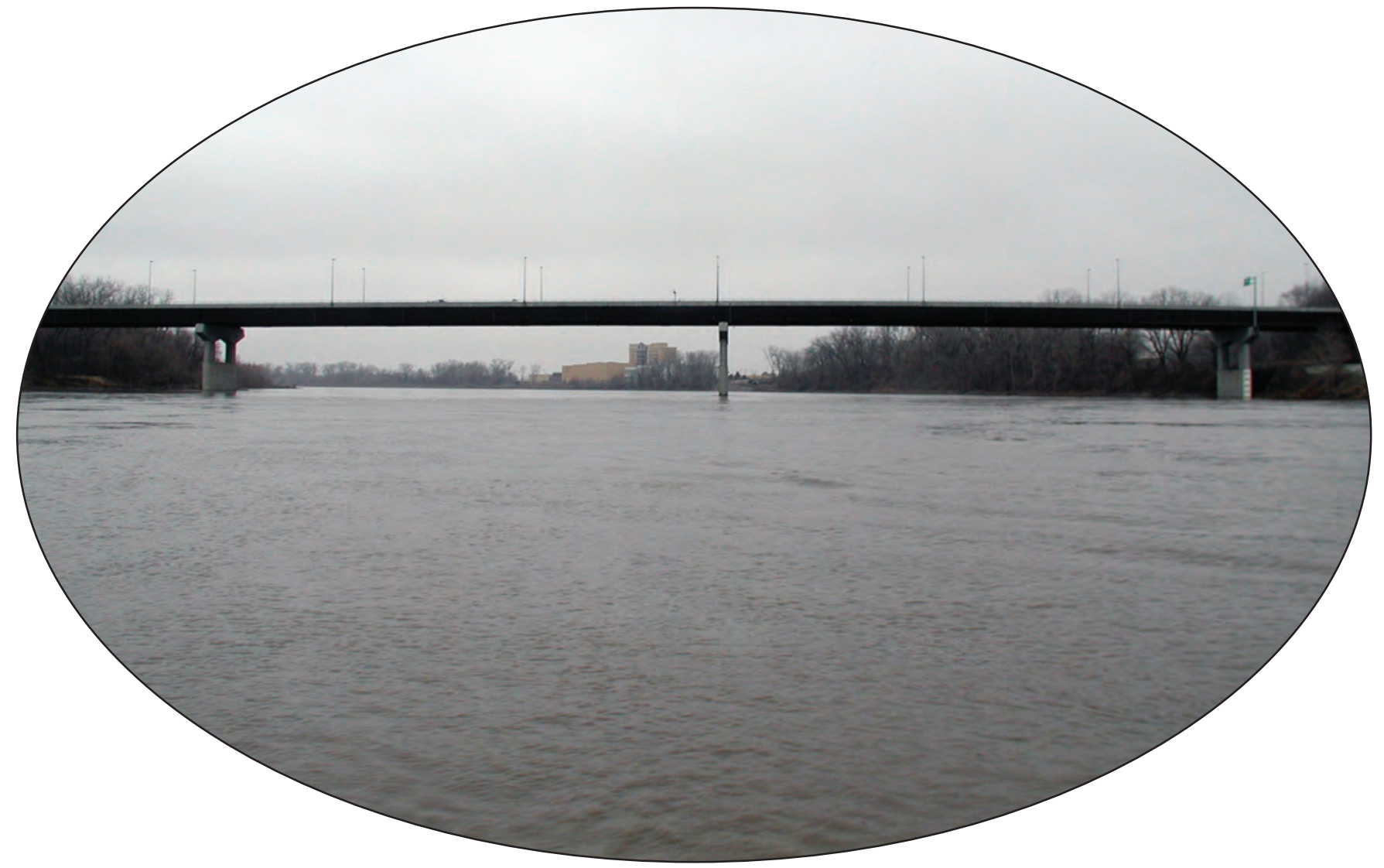

Structure A5817 on State Highway 269. 


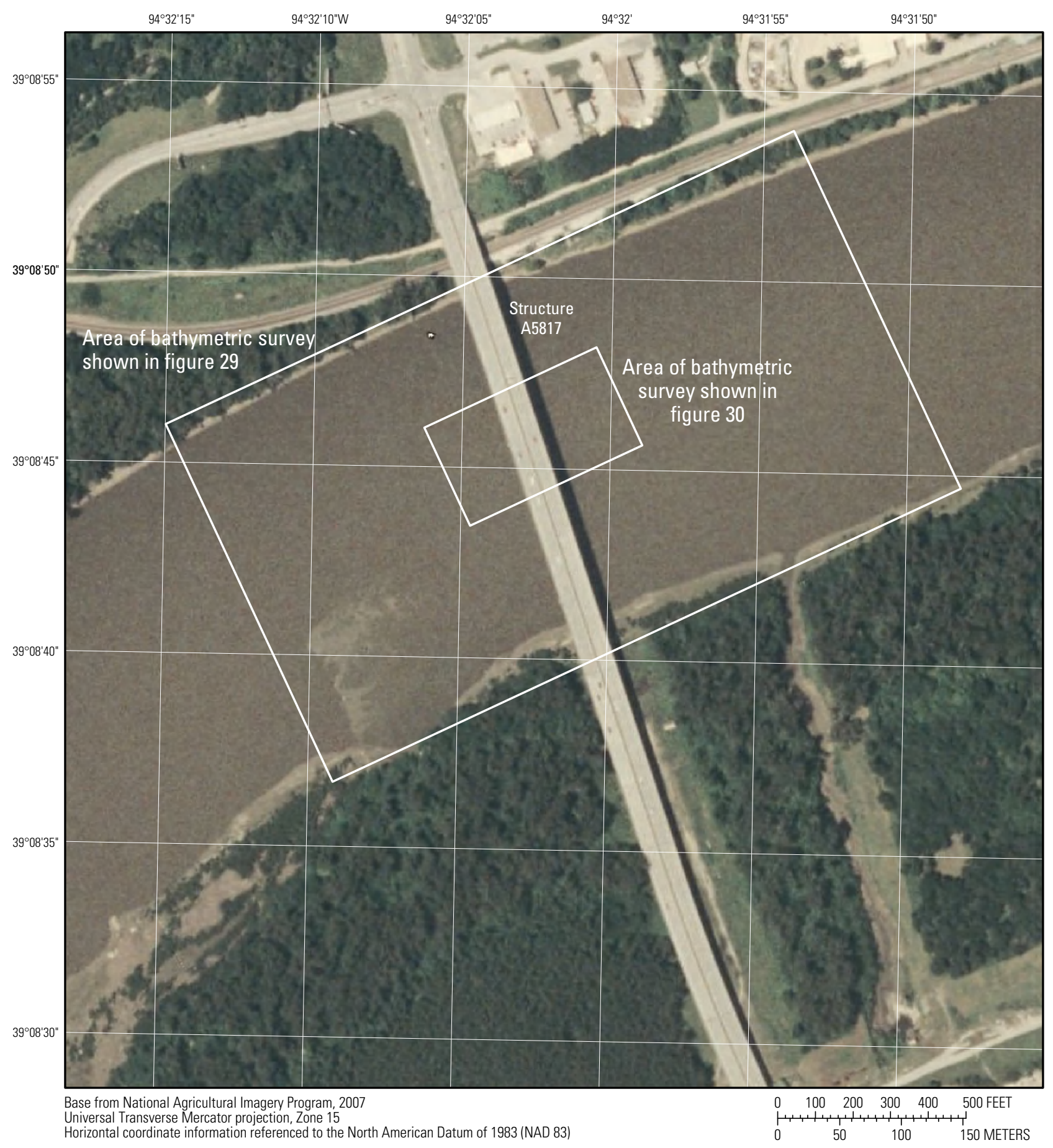

Figure 28. Location of the bathymetric survey area on the Missouri River near structure A5817 on State Highway 269 in Kansas City, Missouri. 


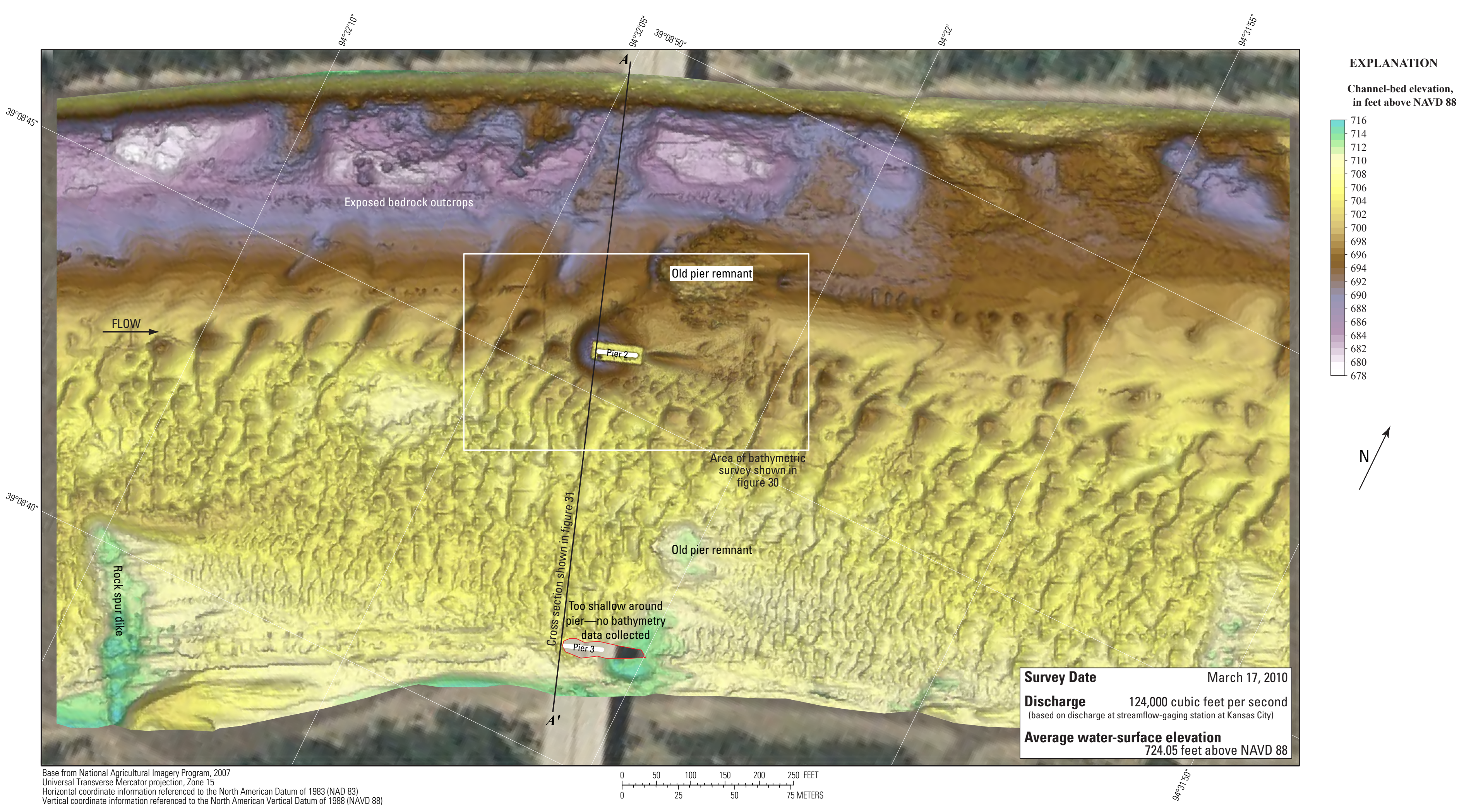

Figure 29. Bathymetric survey of the Missouri River channel in the vicinity of structure A5817 on State Highway 269 in Kansas City, Missouri. 


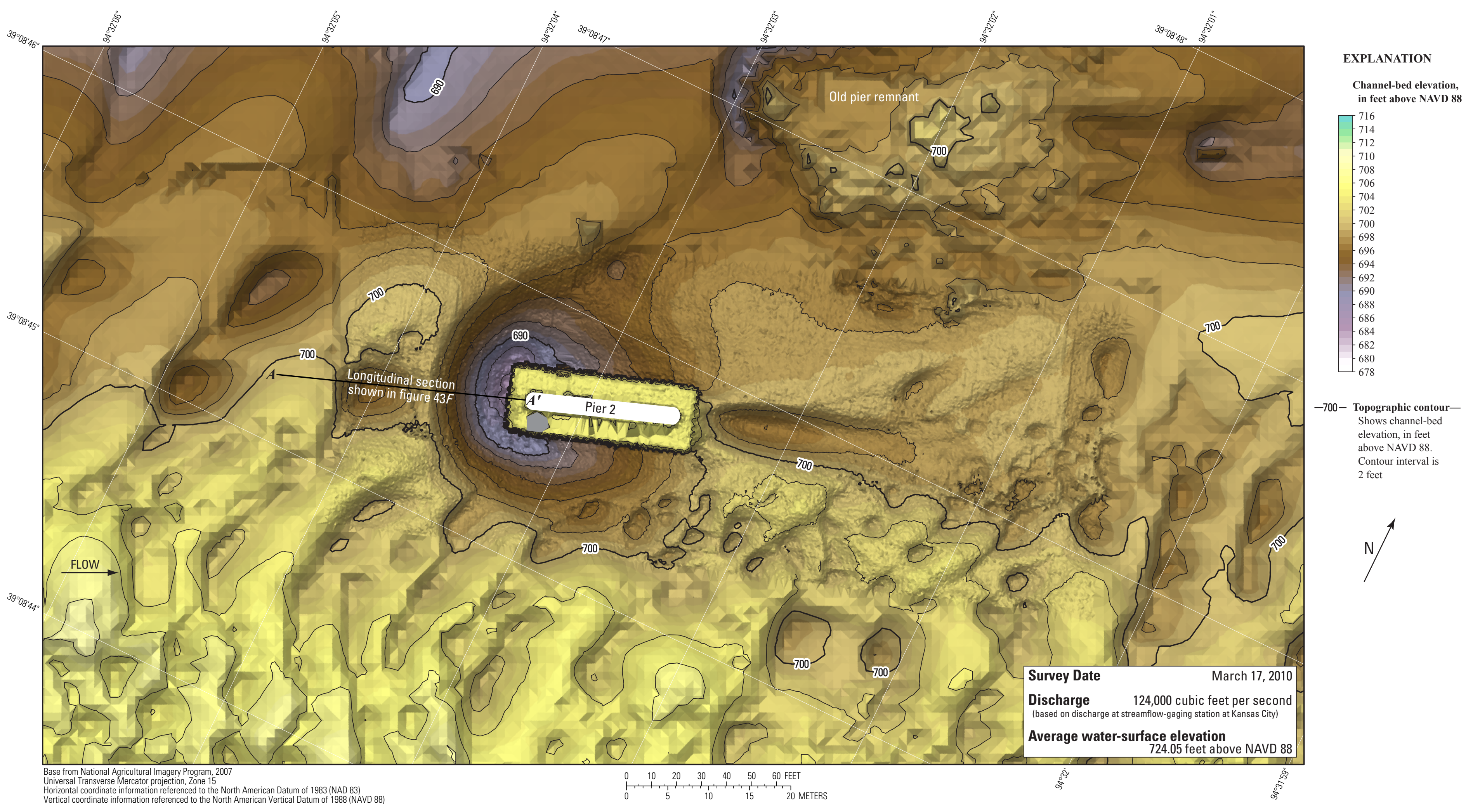

Figure 30. Bathymetric survey of the Missouri River channel in the vicinity of the main channel pier of structure A5817 on State Highway 269 in Kansas City, Missouri. 

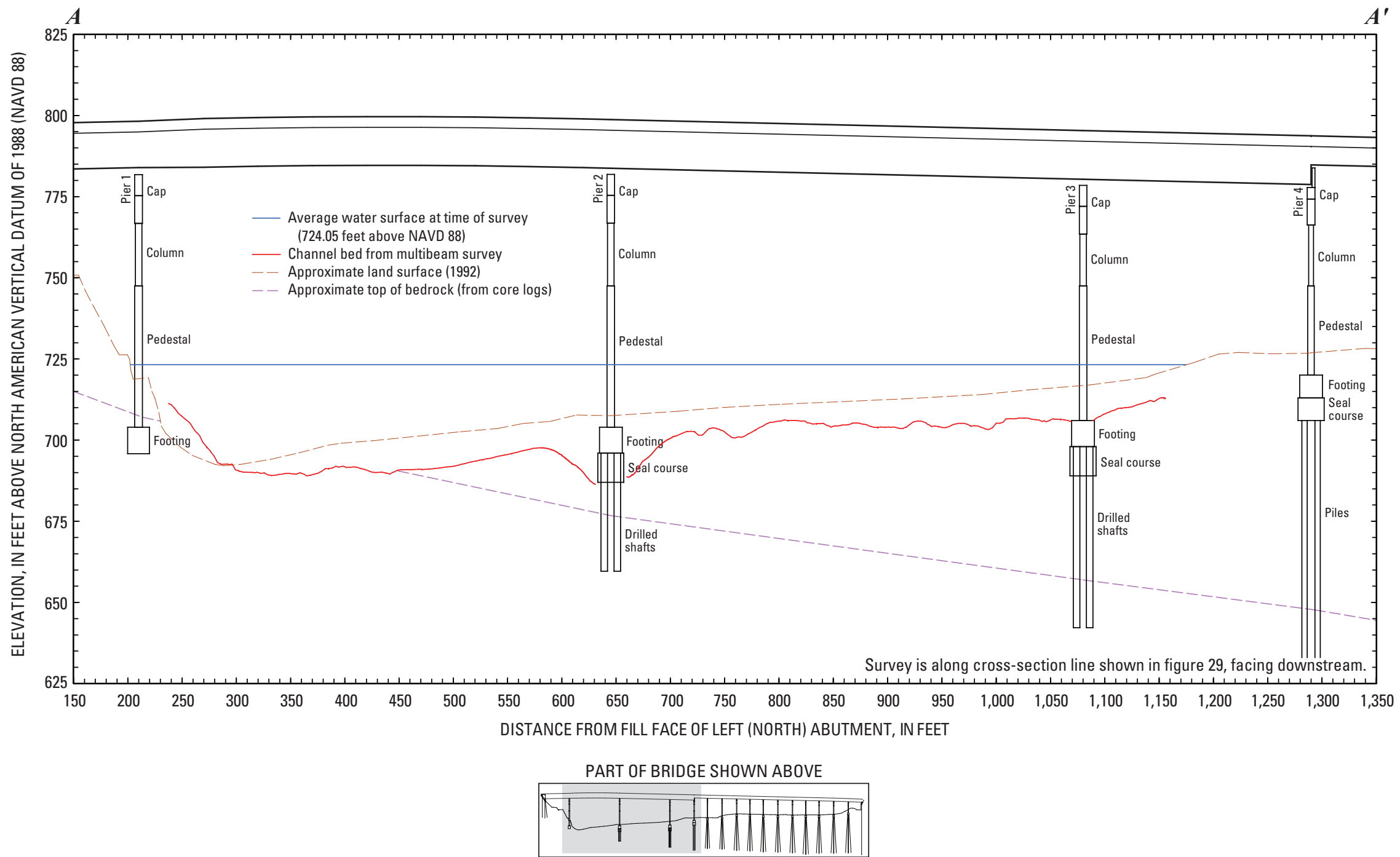

Figure 31. Key features, substructural and superstructural details, and surveyed channel bed of structure A5817 on State Highway 269 over the Missouri River in Kansas City, Missouri. 


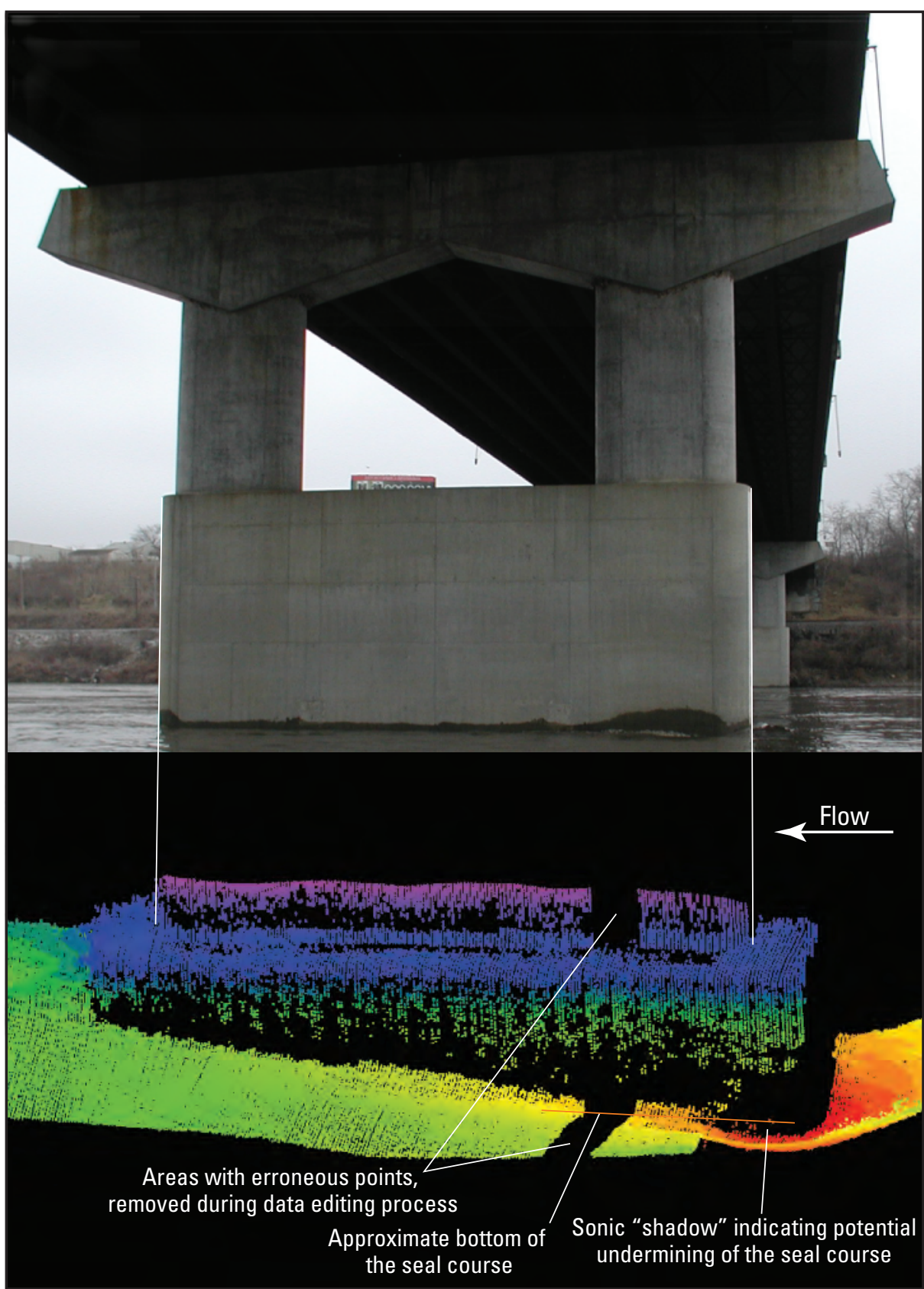

\section{EXPLANATION}

Elevation of point, in feet above the North American Vertical Datum of 1988

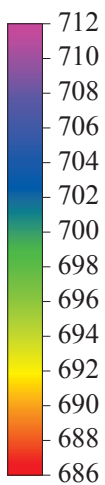

Photograph as shown is a

reversal of actual photograph of the pier from the south side and is shown for visualization purposes only.

Figure 32. Point cloud visualization of the channel bed and left (north) side of the main channel pier of structure A5817 on State Highway 269 over the Missouri River in Kansas City, Missouri. 


\section{Structure A0767 on Interstate 435}

Structure A0767 is on Interstate 435 on the northeastern side Kansas City, Missouri (figs. 1, 33). The survey was conducted on March 17, 2010, and the average water-surface elevation of the river in the survey area determined by the RTK GPS tide solution was $722.52 \mathrm{ft}$ (table 4). Flow on the Missouri River was about $123,000 \mathrm{ft}^{3} / \mathrm{s}$ during the survey (table 4).

The survey area was about $1,800 \mathrm{ft}$ long and about $845 \mathrm{ft}$ wide, extending from bank to bank in the main channel (fig. 34). Piers 7 and 8 were in the water and away from the banks at structure A0767; however, pier 8 was immediately downstream from a rock spur dike and was surrounded by a substantial debris raft, and only limited bathymetric data could be obtained near it (fig. 34). The upstream end of the survey area was about $800 \mathrm{ft}$ upstream from the centerline of structure A0767 at pier 7 (figs. 33, 34). The channel-bed elevations generally ranged from about 682 to $708 \mathrm{ft}$, except downstream from the tip of the rock spur dike, near an unidentified object in the channel downstream from structure A0767, and near pier 7 of structure A0767 (fig. 34). The channel thalweg was along the left (north) bank throughout the surveyed area, and the channel was filled with numerous large and small dune features as well as ripples along both banks (fig. 34). Downstream from the rock spur dike on the right (south) bank near structure A0767, deposits reached an elevation of about $717 \mathrm{ft}$ (fig. 34).

In the immediate vicinity of the main channel pier 7 (fig. 35), a scour hole had a minimum elevation of about $679 \mathrm{ft}$ (table 4), about $10 \mathrm{ft}$ below the elevation of the bottom of the pier seal course of $689.26 \mathrm{ft}$ (fig. 36; table 5). Information from bridge plans indicates that pier 7 is founded on shafts drilled $20 \mathrm{ft}$ into bedrock, with about $19 \mathrm{ft}$ of bed material between the bottom of the scour hole and bedrock (fig. 36; table 5). A point cloud visualization of the multibeam depth points obtained during the survey indicates the bottom of the seal course as a sonic "shadow," with the sides of drilled shafts appearing as points in the shadow (fig. 37).

The surveyed channel bed was similar to the channel bed from the Level II scour survey in 2002 for most of the channel except along the left (north) bank, near pier 7, and along the spur dike near pier 8 (fig. 36). Part of this difference arises from the fact that the Level II survey line was along the downstream face of structure A0767, whereas the bathymetric survey cross-section line was along the upstream face.

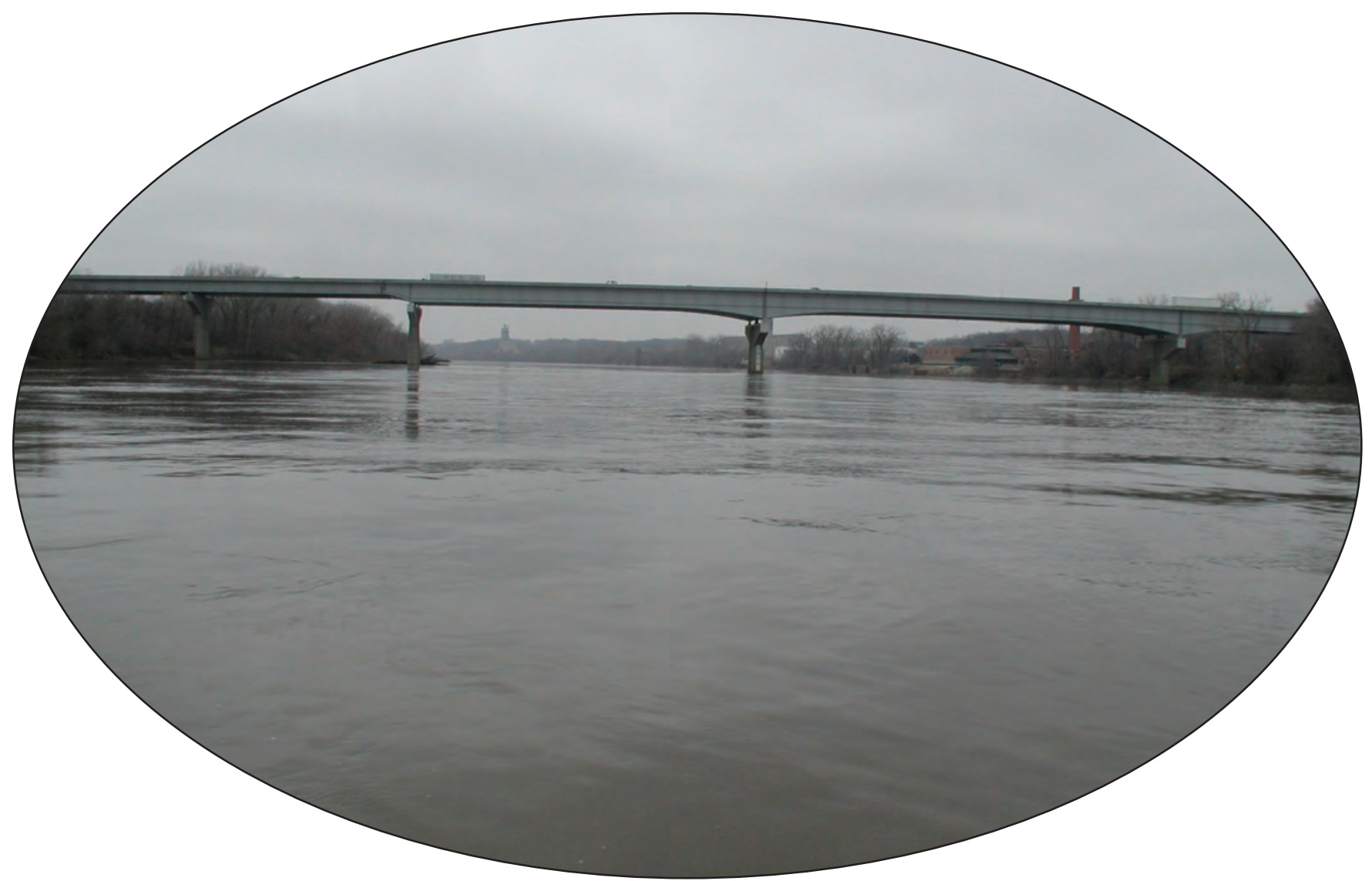

Structure A0767 on Interstate 435. 


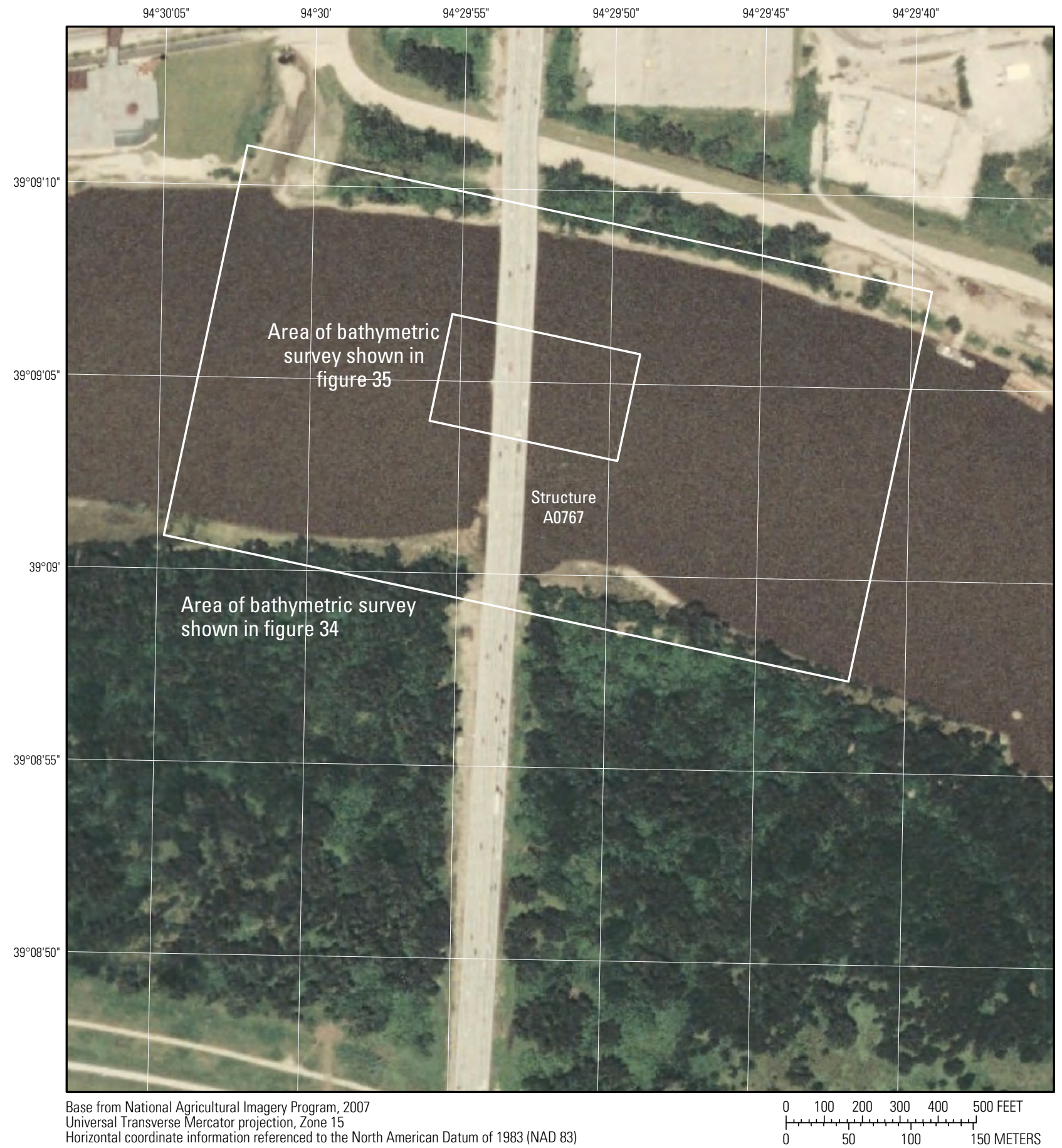

Figure 33. Location of the bathymetric survey area on the Missouri River near structure A0767 on Interstate 435 in Kansas City, Missouri. 


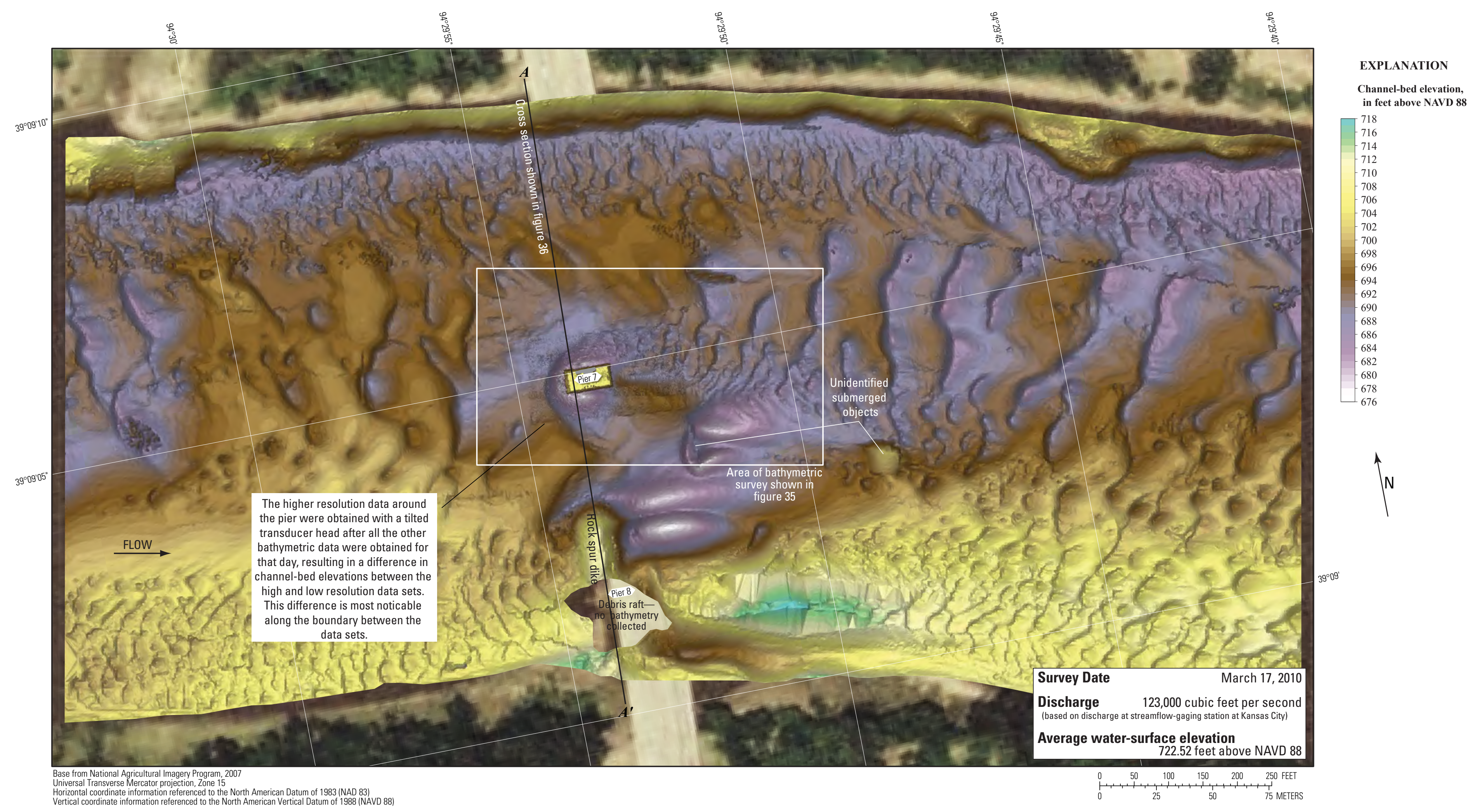

Figure 34. Bathymetric survey of the Missouri River channel in the vicinity of structure A0767 on Interstate 435 in Kansas City, Missouri. 


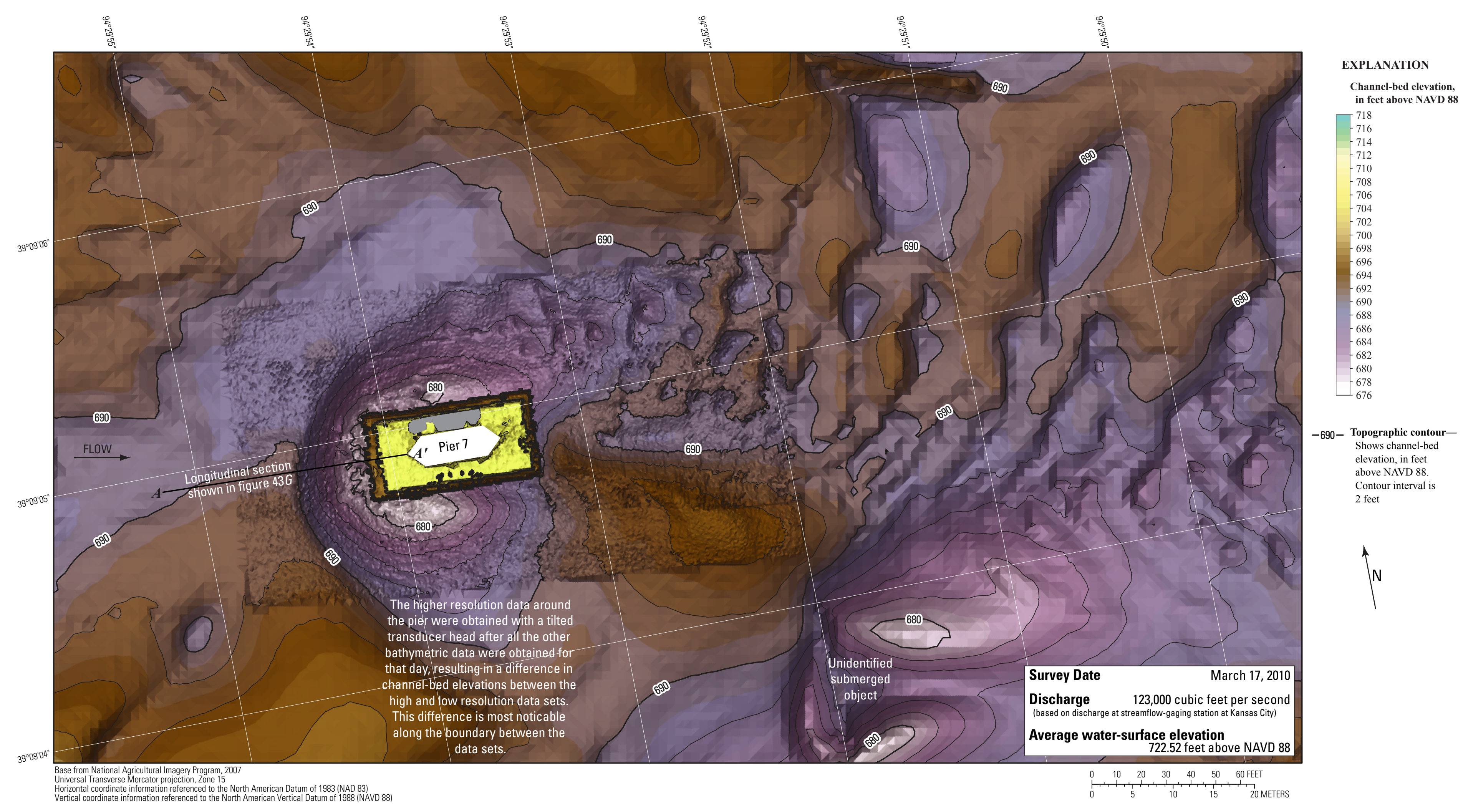

Figure 35. Bathymetric survey of the Missouri River channel in the vicinity of the main channel pier of structure A0767 on Interstate 435 in Kansas City, Missouri. 


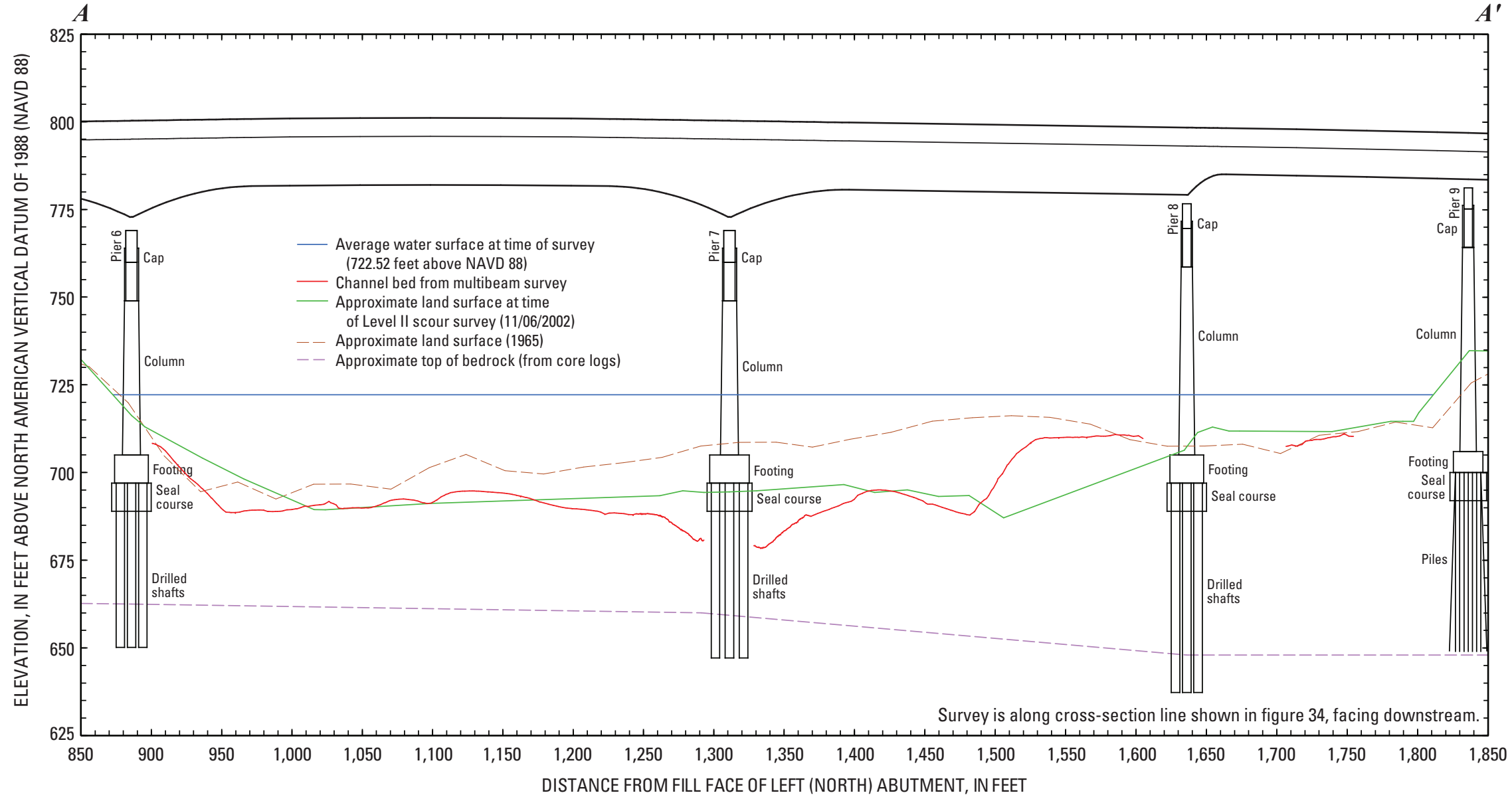

PART OF BRIDGE SHOWN ABOVE

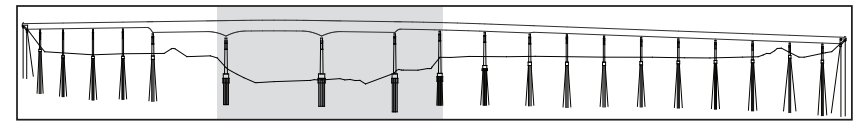

Figure 36. Key features, substructural and superstructural details, and surveyed channel bed of structure A0767 on Interstate 435 over the Missouri River in Kansas City, Missouri. 


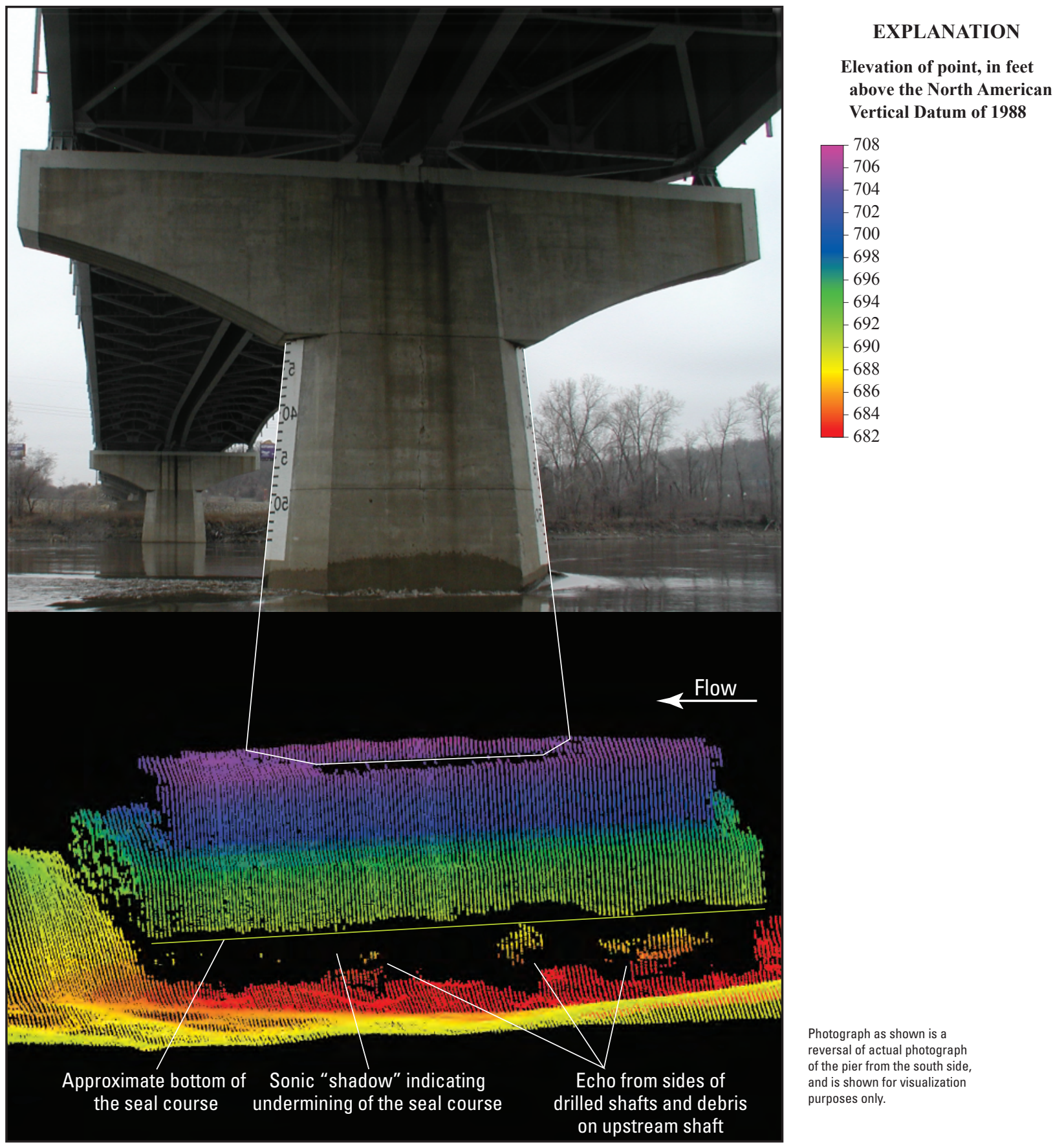

Figure 37. Point cloud visualization of the channel bed and left (north) side of the main channel pier of structure A0767 on Interstate 435 over the Missouri River in Kansas City, Missouri. 


\section{Structures A4757 and L0568 on State Highway 291}

Structures A4757 and L0568 are dual bridges on State Highway 291 on the northeastern side of Kansas City, Missouri (figs. 1, 38). The survey was conducted on March 18, 2010 , and the average water-surface elevation of the river in the survey area determined by the RTK GPS tide solution was $717.20 \mathrm{ft}$ (table 4). Flow on the Missouri River was about $120,000 \mathrm{ft}^{3} / \mathrm{s}$ during the survey (table 4).

The survey area was about 1,780 ft long and about $810 \mathrm{ft}$ wide, extending from bank to bank in the main channel (fig. 39). The upstream end of the survey area was about $740 \mathrm{ft}$ upstream from the centerline between structures A4757 and L0568 (figs. 38, 39). The channel-bed elevations ranged from about 676 to $702 \mathrm{ft}$ for most of the channel bed, except near the main channel piers of structures A4757 and L0568. A narrow channel thalweg was along the left (north) bank at the upstream end of the surveyed area that widened throughout the surveyed area (fig. 39). A few large dune features were detected in the channel upstream from the bridges, as well as numerous smaller dunes and ripples along the right (south) bank upstream from the bridge and across the channel downstream from the bridges (fig. 39). A noticeable channel constriction was at and immediately downstream from the bridges.

In the vicinity of the main channel piers (fig. 40), a large scour hole had a minimum elevation of about $661 \mathrm{ft}$ (table 4), about $25 \mathrm{ft}$ below the average channel bed immediately upstream from the piers. The main channel piers were skewed to approach flow, which caused a wide scour hole with somewhat unique characteristics as compared to scour holes at the other surveyed bridges. Pier 5 of structure L0568 was in the wake of pier $2 \mathrm{C}$ of structure A4757, and, therefore, had no well-defined scour hole specific to it. The point of overall minimum elevation occurred downstream from the right (south) end of pier $2 \mathrm{C}$ of structure $\mathrm{A} 4757$ and to the right (south) of pier 5 of structure L0568 (fig. 40). At the upstream end of pier $2 \mathrm{C}$ of structure $\mathrm{A} 4757$, the minimum elevation was about $666 \mathrm{ft}$, and at the upstream end of pier 5 of structure L0568, the minimum elevation was about $668 \mathrm{ft}$ (fig. 40; table 5). The point of minimum elevation near each pier occurred at the downstream right (south) side of both piers, and was about $665 \mathrm{ft}$ for structure A4757 and about $663 \mathrm{ft}$ for structure L0568 (fig. 40).

Information from bridge plans indicates that the main channel pier of structure A4757 is founded on shafts drilled $20 \mathrm{ft}$ into bedrock, with about $47 \mathrm{ft}$ of bed material between the bottom of the scour hole and bedrock at the upstream end of the pier (fig. 41; table 5), and about $46 \mathrm{ft}$ of bed material between the bottom of the hole and bedrock at the point of minimum elevation at the downstream end of the pier. At the point of minimum elevation, the surveyed channel bed was about $1 \mathrm{ft}$ lower than the bottom of the seal course elevation of $666.26 \mathrm{ft}$ (table 5). The surveyed bed was about $15 \mathrm{ft}$ deeper than the channel bed from the Level II scour survey in 2002 on the left (north) side of the channel, and about 10 feet shallower on the right (south) side, except near the right (south) bank (fig. 41).

Information from bridge plans indicates that the main channel pier of structure L0568 is a caisson on bedrock (fig. 42), with about $50 \mathrm{ft}$ of bed material between the bottom of the scour hole and bedrock at the upstream end of the pier (fig. 42; table 5), and about $45 \mathrm{ft}$ of bed material between the bottom of the hole and bedrock at the point of minimum elevation at the downstream end of the pier. Similar to structure A4757, the surveyed channel bed was about $15 \mathrm{ft}$ deeper than the channel bed from the Level II scour survey in 2002 on the left (north) side of the channel and varied from about $10 \mathrm{ft}$ deeper to $10 \mathrm{ft}$ shallower on the right (south) side of the channel (fig. 42).

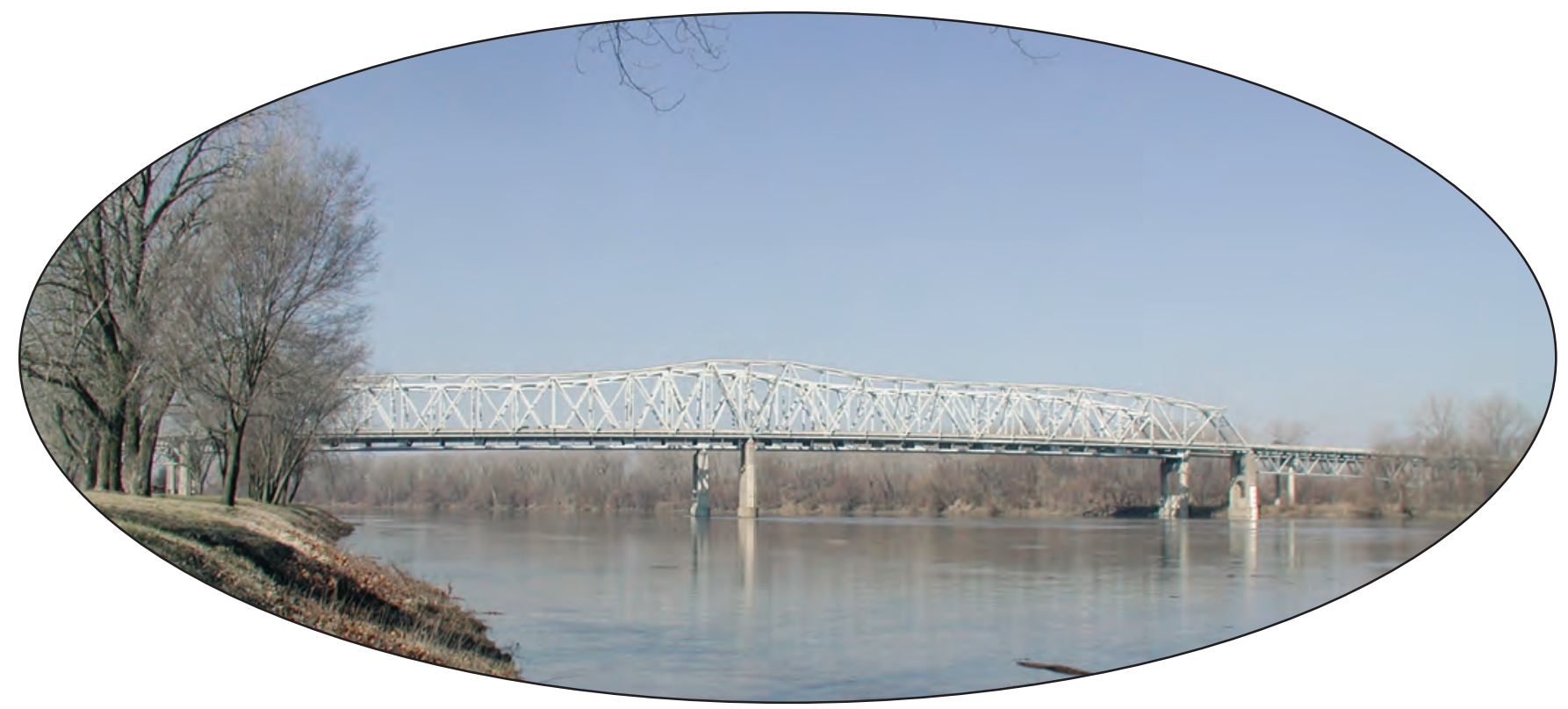

Structures A4757 and L0568 on State Highway 291. Structure L0568 is in the foreground and A4757 is in the background. 


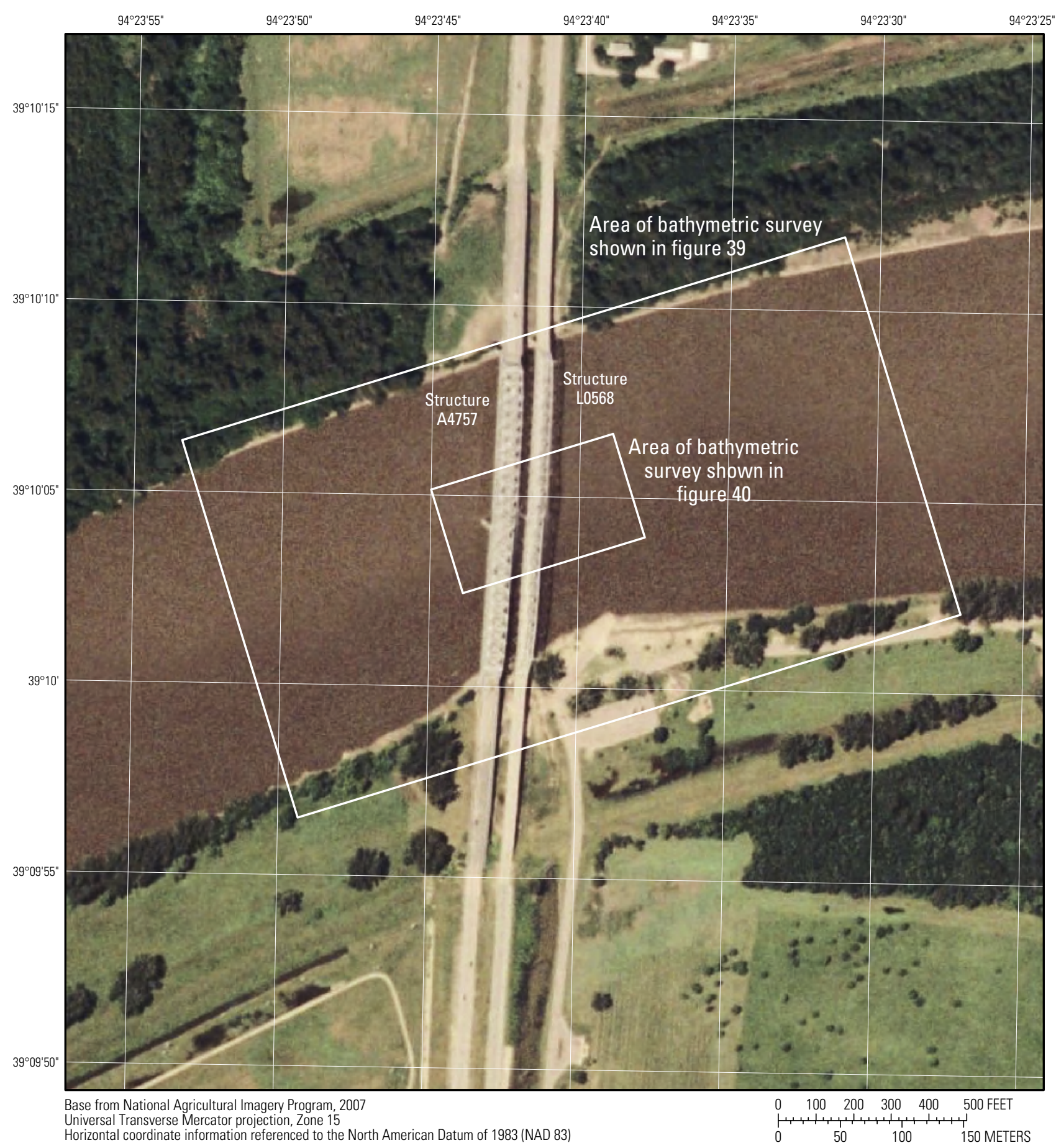

Figure 38. Location of the bathymetric survey area on the Missouri River near structures A4757 and L0568 on State Highway 291 in Kansas City, Missouri. 

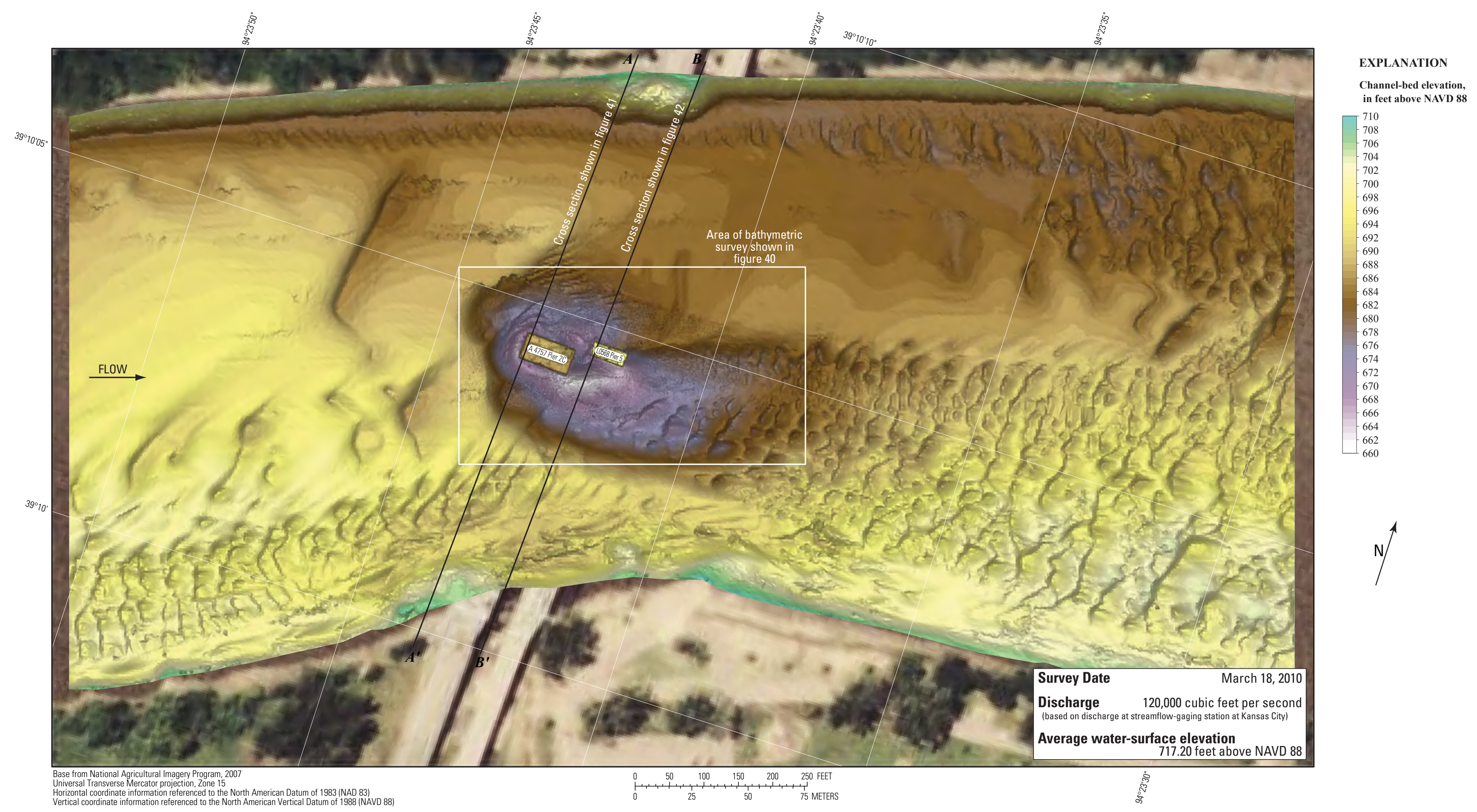

Figure 39. Bathymetric survey of the Missouri River channel in the vicinity of structures A4757 and L0568 on State Highway 291 in Kansas City, Missouri. 


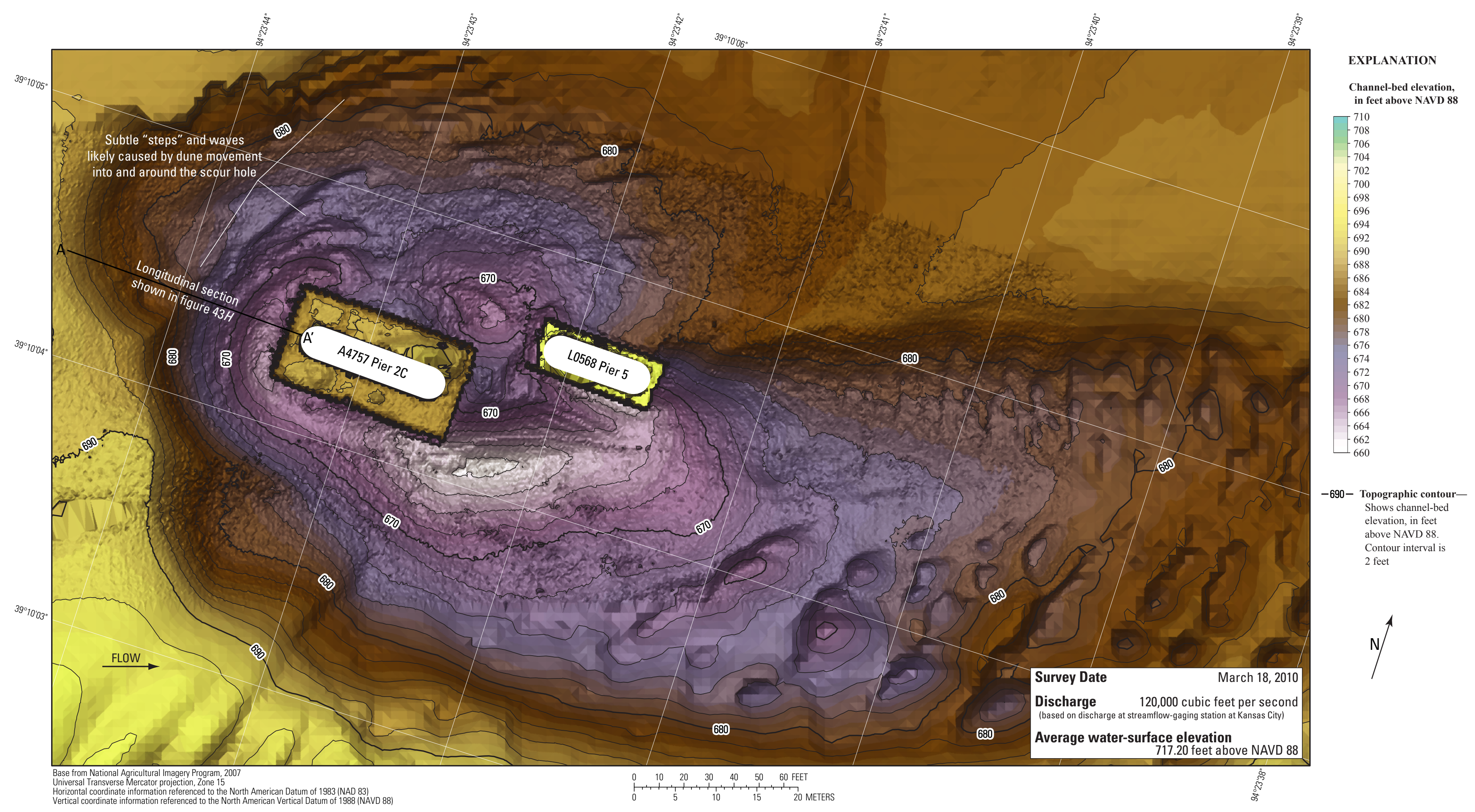

Figure 40. Bathymetric survey of the Missouri River channel in the vicinity of the main channel piers of structures A4757 and L0568 on State Highway 291 in Kansas City, Missouri. 

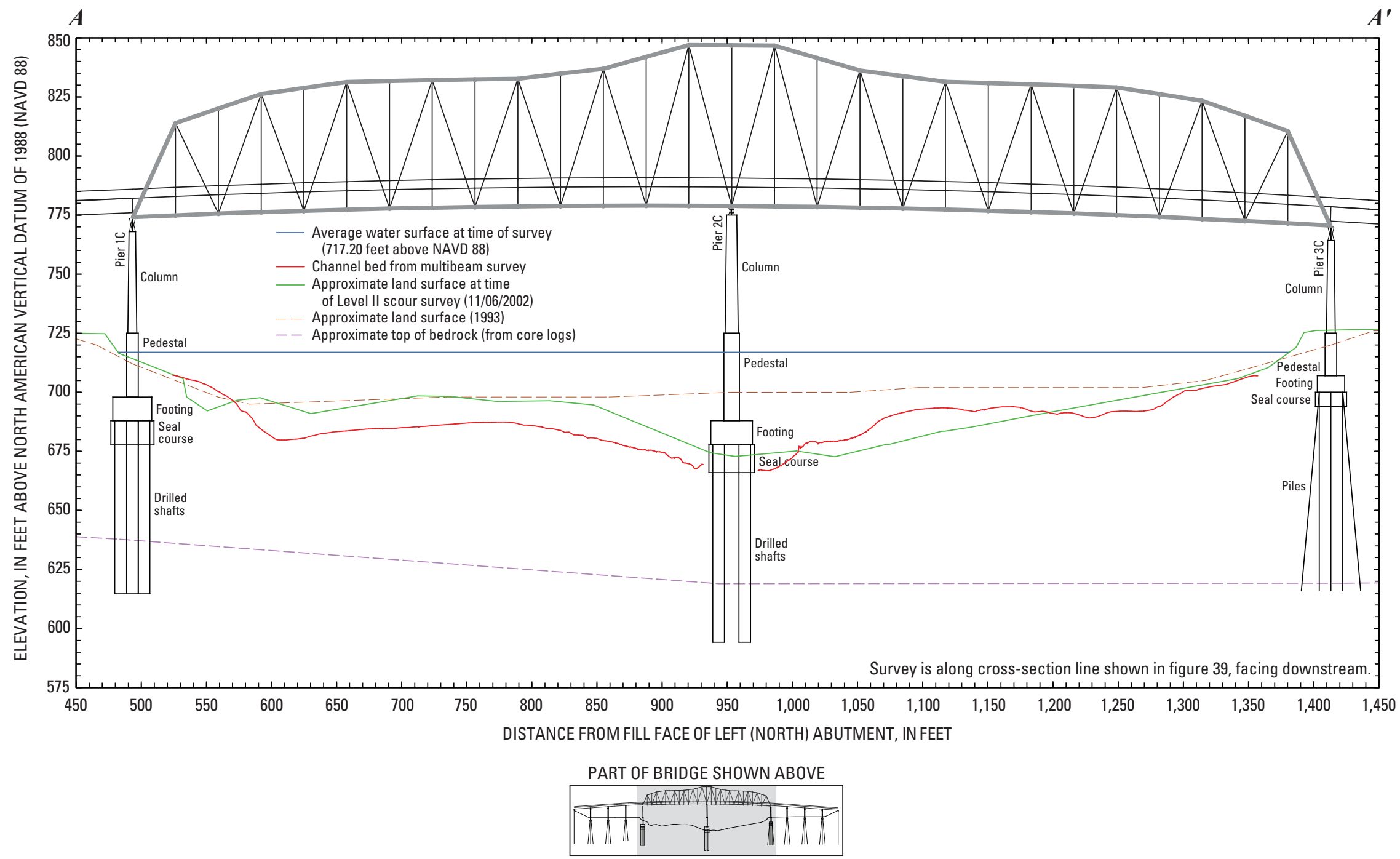

Figure 41. Key features, substructural and superstructural details, and surveyed channel bed of structure A4757 on State Highway 291 over the Missouri River in Kansas City, Missouri. 

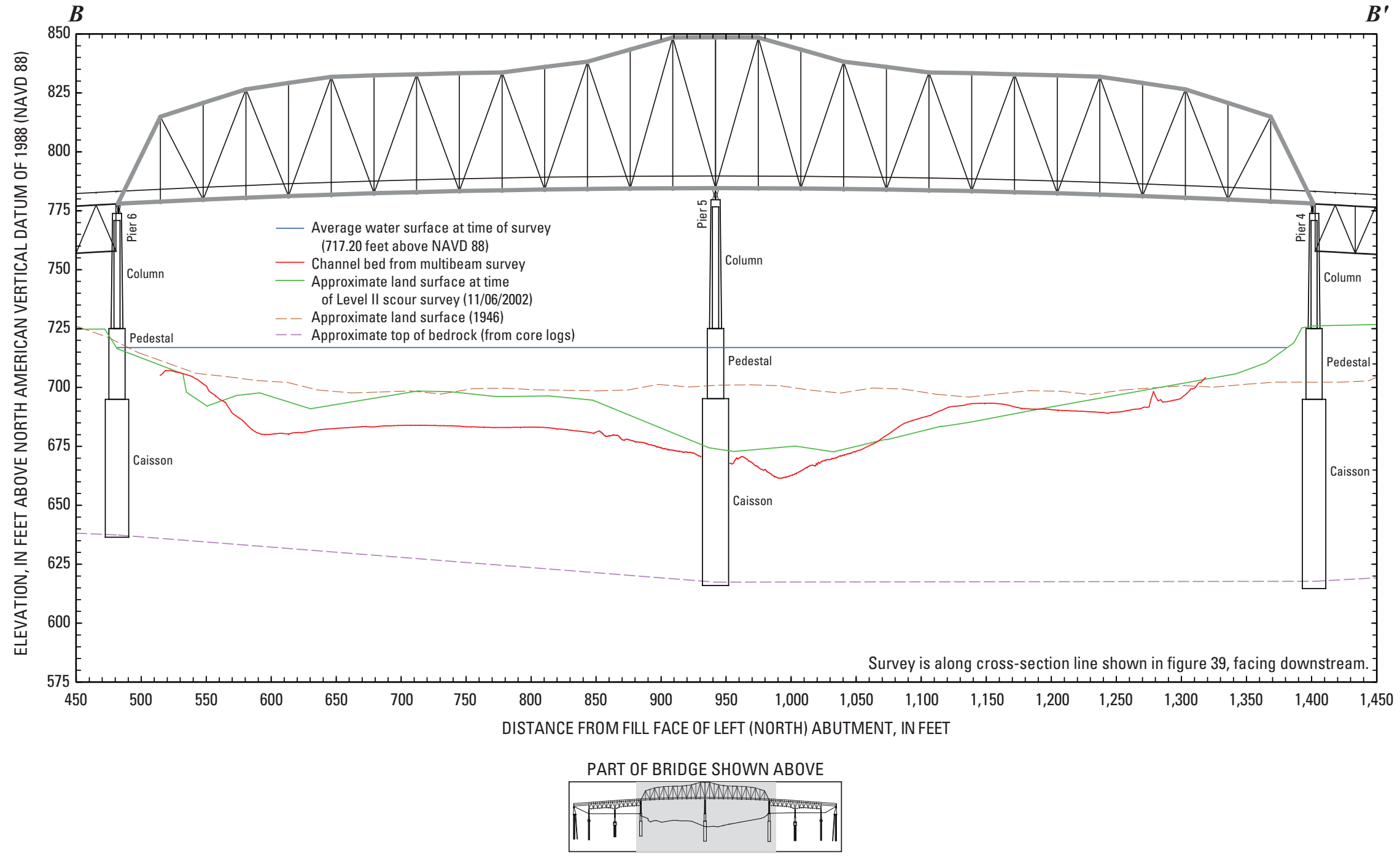

Figure 42. Key features, substructural and superstructural details, and surveyed channel bed of structure L0568 on State Highway 291 over the Missouri River in Kansas City, Missouri. 


\section{General Findings and Implications}

Several of the findings at each surveyed bridge were common to all of the bridges, and some findings only appear when the surveys are examined as a set. These general findings are of benefit to the assessment of scour at the surveyed bridges, as well as other bridges in the vicinity or in similar situations.

\section{Shape of Scour Holes}

A scour hole was present at every pier for which bathymetry could be obtained and varied in depth relative to the upstream channel bed. A longitudinal profile was drawn upstream from the nose of each pier with a well-defined scour hole (fig. 43), and the approximate frontal slope determined for each hole (table 5). The frontal slope was not determined for the poorly defined scour hole at the right main channel pier (pier 6) of structure A4060 (fig. 23) or the main channel pier at structure L0568, which had no scour hole specific to it (fig. 40). The approximate frontal slope of the scour holes at each of the remaining piers ranged from 1.77 to 2.49 (table 5). Richardson and Davis (2001) noted that the side slope of a scour hole in cohesionless sand could range from 1.0 to 1.8 , depending on the composition of the bed material and its wet angle of repose. The slope values determined in the Kansas City area are somewhat greater than the range of values noted in Richardson and Davis (2001), except for structure A1800.

As noted in the previous site-specific data, the movement of bed material manifested as dune features affected the bathymetric data at several of the bridges where a tilted transducer head was used to obtain depth points at the pier after the general channel bathymetric data had been collected. However, the shape of the scour holes at several of the bridges displayed the effects of these dune movements as well. The scour hole upstream from structure K0456 has a squarish upstream edge, which likely is the result of dunes moving into and around the hole (figs. 13, 14). A similar squarish upstream edge was observed at structure A4649 (figs. 18, 19) and structure A4757 (figs. 39, 40). The scour hole at structure A1 800 also was affected by dune movement, displayed by subtle "steps" and waves present along the sides of the hole (fig. 9) and in the longitudinal profile (fig. 43A). Other profiles displayed similar, but more subtle "steps" in the longitudinal profiles (figs. 40, $43 E, 43 H)$.

All of the bridges surveyed except structure A4060 had piers that were skewed to flow, resulting in asymmetric scour holes at most of the bridges. The scour hole typically was deeper and longer on the side of the pier with impinging flow, and some amount of deposition was on the leeward side (figs. 10, 11, 14, 15, 19, 20, 30, 31, 35, 36, 40, 41). Bridges with less than $5^{\circ}$ of skew to the approach flow occasionally had asymmetric scour holes [structures K0456 and A0450 (figs. 13, 14)], and occasionally not [structure A5817 (figs. 29, 30)]. Structures A4757 and L0568 had the largest skew (about $20^{\circ}$ ), which resulted in a large asymmetric scour hole that nearly encompassed the main channel piers of both bridges (figs. 39, 40). Although the piers of structure A4060 were aligned to the flow, the railroad bridge piers upstream from structure A4060 were skewed to flow (figs. 22, 23, 26), and the effects of the asymmetric scour hole upstream from the right main channel pier (pier 6) affected the shape and size of the hole at that pier (fig. 23).

\section{Long-Term Channel-Bed Changes}

With the exception of structure A0767, all of the bridges for which a Level II scour assessment was completed had a lower channel-bed elevation during the bathymetric surveys than during the Level II survey in 2002, and all of the bridges had a lower channel-bed elevation during the 2010 surveys than when the bridge had been built. Researchers have stated that water stage appears to be decreasing with time on the Mississippi River for discharges less than flood stage (Brauer, 2009; Huizinga, 2009). Huizinga (2009) stated that this likely is caused by a combination of channel deepening caused by rock spur dikes in the channel and a decrease in the overall sediment load on the Missouri and Mississippi Rivers caused by upstream reservoirs. A similar but more limited analysis to that in Huizinga (2009) was completed using data from discharge measurements at the streamgage on the Missouri River at Kansas City, Missouri, where water-surface elevations for a variety of discharge ranges from measurements at the streamgage were plotted (fig. 44). Water-surface elevations were used instead of stage to remove the effects of a $10 \mathrm{ft}$ datum shift in 1989. A decrease in the water-surface elevations with time at the Kansas City streamgage was similar to that observed on the Mississippi River at St. Louis, Missouri, and Chester, Illinois (Huizinga, 2009), which implies a similar decrease in the channel-bed elevations with time at the Kansas City streamgage. The decrease with time appears to be greater for lower discharges than for higher discharges (fig. 44). The range of discharges observed during the bathymetric surveys was 120,000 to $129,000 \mathrm{ft}^{3} / \mathrm{s}$, which corresponds to the $125,000 \mathrm{ft}^{3} / \mathrm{s}+/-4$ percent discharge range in figure 44 .

Dividing the total measured area by the measured top width from discharge measurements gives an average depth of flow. Subtracting the average depth of flow from the watersurface elevation value for a measurement provides an average channel-bed elevation. The average channel-bed elevation with time for all the measurements at the Kansas City, Missouri, streamgage is shown in figure 45 . With the exception of several outliers that likely result from large floods (Huizinga, 2009), the average channel-bed elevation has changed markedly with time. From the late 1920's to 1940, the average channel-bed elevation appeared to be increasing with time, whereas the average channel-bed elevation has been decreasing with time ever since (fig. 45). The general trend of the average channel-bed elevation with time is concave downward, which implies that the rate of change of the average channel-bed elevations is increasing with time, which likely is caused by sediment being trapped in upstream reservoirs. 


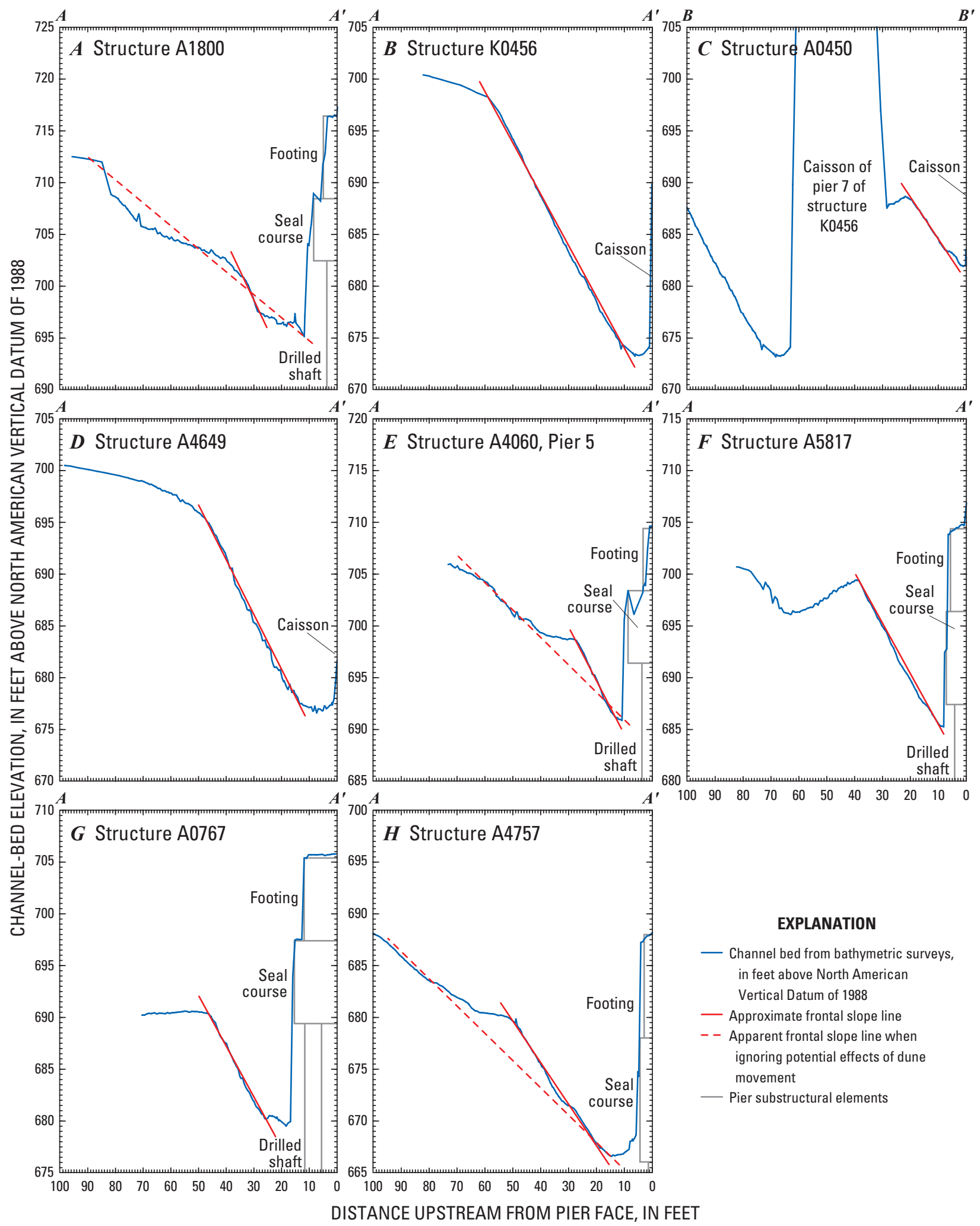

Figure 43. Longitudinal profiles upstream from piers at the structures surveyed on the Missouri River at Kansas City, Missouri. 


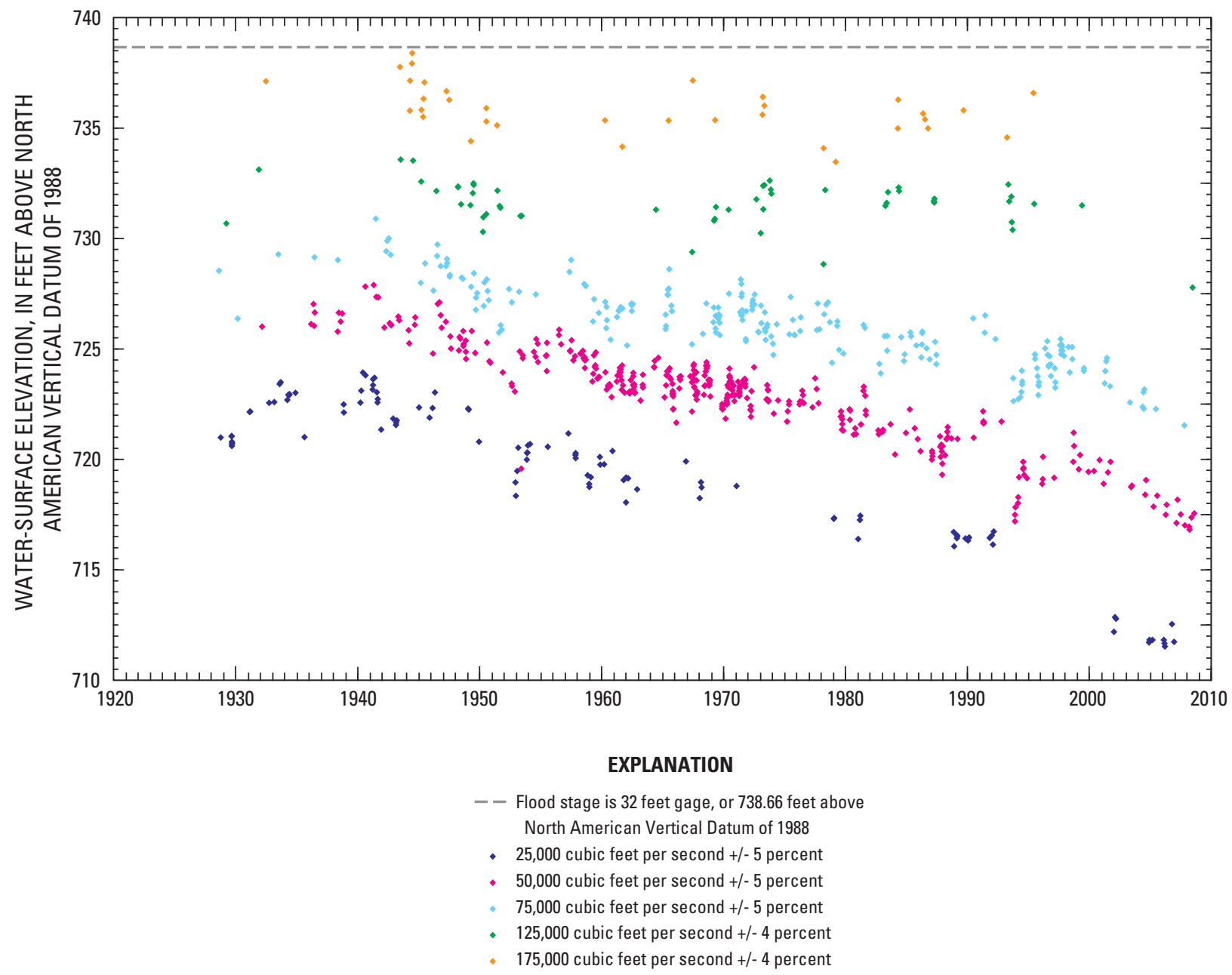

Figure 44. Water-surface elevation for a given discharge range with time from measurements made at the streamflowgaging station on the Missouri River at Kansas City, Missouri (station number 06893000).

Since the time of the 1993 flood, the average channel-bed elevation has decreased by about $6 \mathrm{ft}$ (fig. 45). This long-term change in channel-bed elevation is part of the reason that the pier foundations were exposed and undermined at the time of the bathymetric surveys.

\section{Effects of Moderate Flooding During Surveys}

Richardson and Davis (2001) separate long-term aggradation and degradation of a channel from the contraction and local scour that occur at a bridge site during floods. Contraction scour is the general change in the channel-bed elevation across a bridge opening resulting from the passage of a flood through a constriction. Local scour is the localized erosion of material caused by flow vortex action that forms near bridge piers and abutments. Although all of the scour processes (longterm, contraction, and local scour) continually are at work, contraction and local scour generally are cyclic, resulting in a decrease and increase of the channel-bed elevation during the passage of a flood.
Flood durations on the Missouri River at Kansas City generally are measured in weeks and months because of the large upstream drainage area. Therefore, contraction and local scour effects at the bridges on the Missouri River in the Kansas City area appear to be well-established and apparently stable. Nevertheless, the Missouri River was in moderate flood conditions during the week of surveying, which would have an effect on the local scour at the bridge sites. Huizinga (2009) observed that the streamgages on the Mississippi River at St. Louis, Missouri, and Chester, Illinois, routinely experience channel degradation and infilling during the passage of a flood. During the 1993 flood, the measurement section at the St. Louis streamgage indicated as much as $24 \mathrm{ft}$ of fluctuation in the channel thalweg during the flood, but the post-flood channel bed configuration was similar to the pre-flood configuration. The measurement section at the Chester streamgage indicated steady degradation of more than $18 \mathrm{ft}$ in the channel thalweg up to the peak of the flood, and steady aggradation after the peak, with a post-flood configuration within about $8 \mathrm{ft}$ of the pre-flood configuration. Therefore, the scour holes 


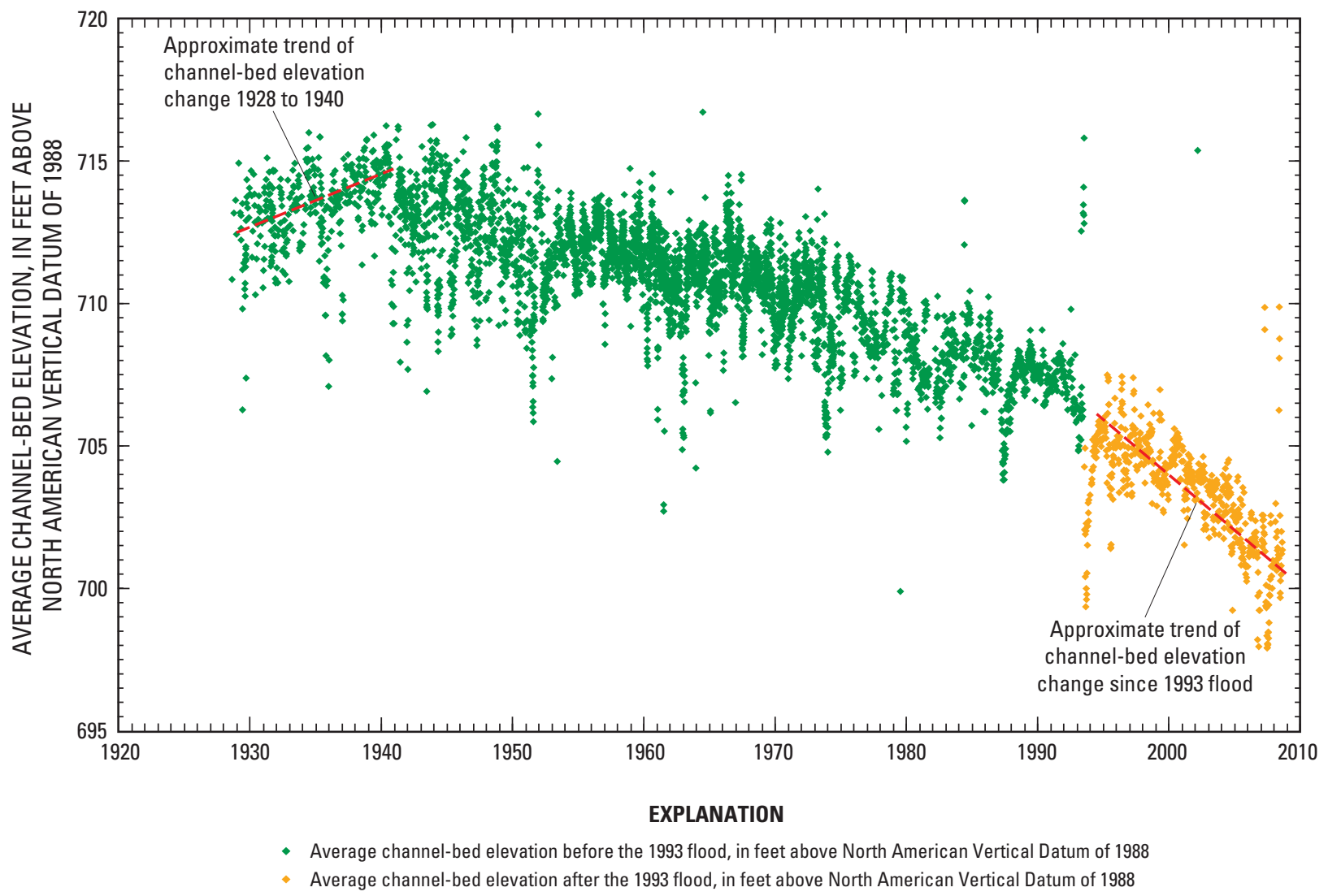

Figure 45. Average channel-bed elevation with time from measurements made at the streamflow-gaging station on the Missouri River at Kansas City, Missouri (station number 06893000).

observed at the bridges in the Kansas City area likely are transient, with some infilling upon recession of the flood conditions. If the bridges were to be surveyed at low-flow conditions, the scour holes likely would be smaller.

\section{Error Estimation}

To estimate the potential errors in the surveys, the Combined Uncertainty Bathymetric Estimator (CUBE) method (Calder and Mayer, 2003) as implemented in the HYPACK $^{\circledR} /$ HYSWEEP $^{\circledR}$ software (HYPACK, Inc., 2009) was used to estimate total propagated errors (TPE) for the gridded surface of each survey area. The CUBE method effectively allows all random system component errors and resolution effects to be combined and propagated through the survey processing steps, which provides a robust estimate of the spatial distribution of possible error within the survey area (Kevin Oberg, U.S. Geological Survey, written commun., 2010). Thus, the TPE of a point is a measure of the accuracy to be expected for such a point, when all relevant error sources are taken into account (Kevin Oberg, written commun., 2010). A representative example of the spatial distribution of TPE typically observed in the survey data is shown in figure 46 for the bathymetric data at structure A1800.

The largest TPE in the Kansas City surveys was about $2.8 \mathrm{ft}$; however, TPE values of this magnitude typically occurred near high-relief features, such as the front or side of a pier footing or large submerged object (fig. 46). More typically, TPE values were less than $1.5 \mathrm{ft}$, with larger values occurring near moderate-relief features (banks, dune faces, and scour holes; fig. 46). Occasionally, these larger TPE values also occurred in the outermost beam portions of the multibeam swath in the overlap with an adjacent swath, typically in the channel thalweg where substantial bed movement would occur between survey passes (fig. 46). Substantial parts of the channel bed at all of the surveyed sites had TPE values of $0.5 \mathrm{ft}$ or less, and the tops of bridge substructural elements (pier footings and seal courses) typically had TPE values of $0.2 \mathrm{ft}$ or less (fig. 46). 


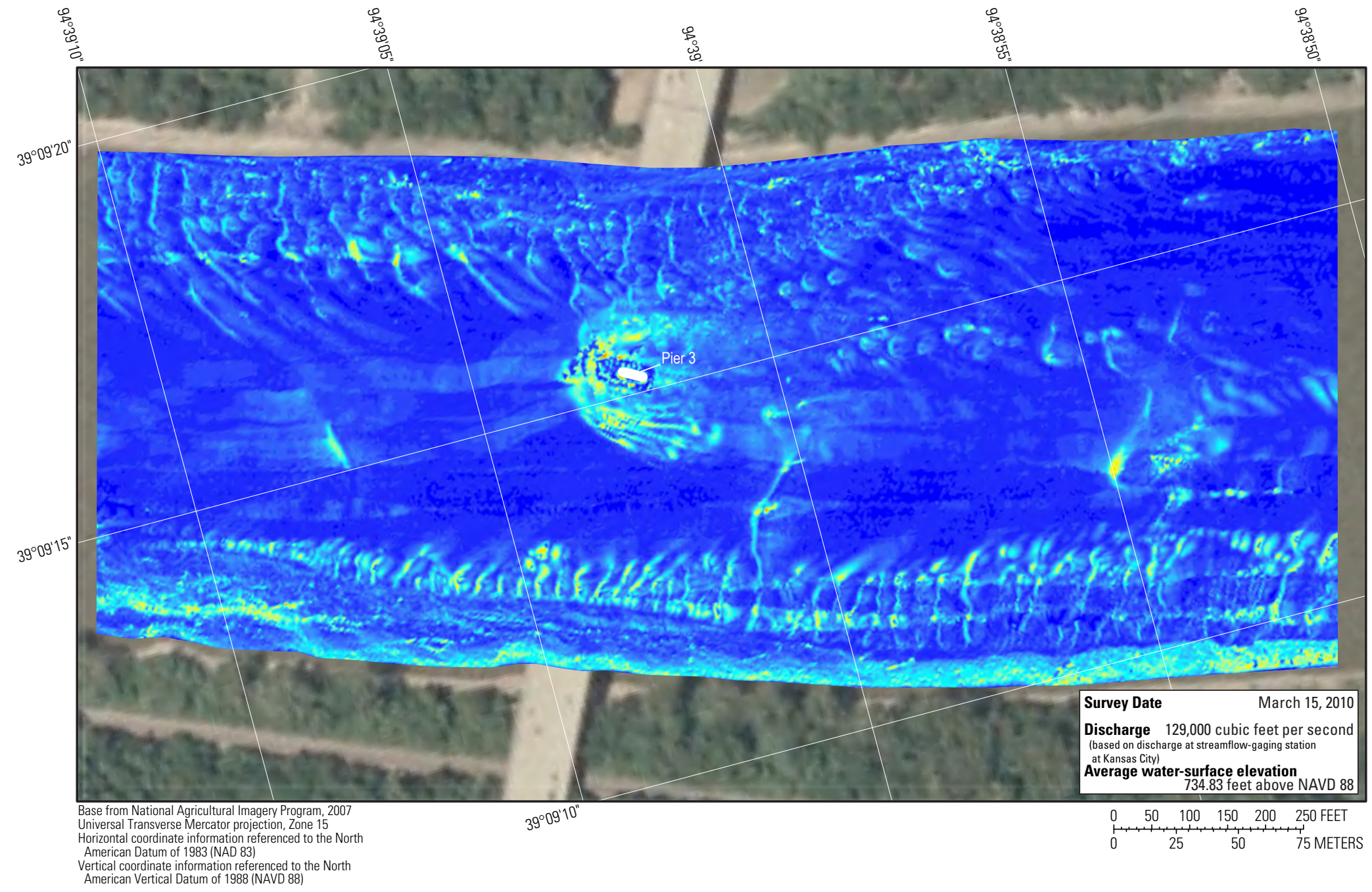

\section{EXPLANATION}

Total propagated error of channelin feet

2.8

2.6

2.6
2.4
2.2

2.2
2.0
1.8

Figure 46. Total propagated error of bathymetric data from the Missouri River channel in the vicinity of structure A1800 on Interstate 635 in Kansas City, Missouri. 


\section{Summary}

Bathymetric surveys were conducted on the Missouri River in the vicinity of nine bridges at seven highway crossings in Kansas City, Missouri, by the U.S. Geological Survey in cooperation with the Missouri Department of Transportation. A multibeam echo sounder mapping system was used to obtain channel-bed elevations for areas ranging from 1,640 to 1,800 feet long and extending from bank to bank in the main channel of the Missouri River. These bathymetric scans will be used by the Missouri Department of Transportation to assess the condition of the bridges for stability and integrity with respect to bridge scour.

At nearly all of the surveyed bridges, large dune features were detected in the channel, as well as numerous smaller dunes and ripples. Several of the sites are on or near bends in the river, resulting in a deep channel thalweg on the outside of the bend at these sites. At structure A5817 on State Highway 269 , evidence of bedrock exposure was in the channel thalweg.

Bathymetric data were collected around every pier that was in water, except those at the edge of water or in extremely shallow water, and one pier at structure A0767 on Interstate 435 , which was surrounded by a large debris raft. A scour hole was present at every pier for which bathymetry could be obtained. At bridges with caisson foundations, the surveyed channel bed at the bottom of the scour hole generally was 40 to 50 feet above the bottom of the caisson at bedrock level, except at structure A4649 on U.S. Highway 169, where the bottom of the scour hole was about 5 feet above bedrock.

At bridges with drilled shaft foundations, the upstream end of the seal course was exposed at all of the piers except the piers on the right (south) side of the channel at structure A5817 on State Highway 269 and structure A0767 on Interstate 435 . Furthermore, the bottom of the scour hole generally was below the bottom of the seal course for piers with this foundation type. The minimum elevation of the scour hole at the main channel pier of structure A0767 on Interstate 435 was about 10 feet below the bottom of the seal course, and the sides of the drilled shafts were evident in a point cloud visualization of the data at that pier. Undermining of the seal course was evident as a sonic "shadow" in the point cloud visualization of several of the piers. The bottom of the scour hole generally was 10 to 45 feet above bedrock, and drilled shafts generally penetrate 20 feet into bedrock.

The scour hole at a given pier varied in depth relative to the upstream channel bed, depending on the presence and proximity of other piers or structures upstream from the pier in question. At piers with well-defined scour holes, the frontal slopes of the holes were greater than recommended values in the literature, except for structure A1800. The shape of the holes appeared to be affected by the movement of dune features into and around the holes. All of the structures surveyed except structure A4060 had piers skewed to approach flow, and the resultant scour holes displayed characteristics of deposition on the leeward side of the pier and greater depth on the side of the pier with impinging flow.

The channel bed at nearly all of the surveyed bridges was lower than the channel bed at the time of Level II scour assessments in 2002 and was lower than the channel bed at time of construction at all of the surveyed bridges. An analysis of measurement data from the streamgage on the Missouri River at Kansas City, Missouri, confirmed the lowering of the channel-bed elevations with time.

The Missouri River was in moderate flood conditions at the time of the surveys, and the size of the scour holes likely was affected by the conditions. It is likely that the scour holes would be smaller during conditions of low flow.

\section{References Cited}

Applanix Corporation, 2006, POS-MV TM V4 user guide, Rev. 0: Richmond Hill, Ontario, Canada, PUBS-MAN000513,369 p.

Applanix Corporation, 2009, POS-Pac ${ }^{\mathrm{TM}} \mathrm{MMS}^{\mathrm{TM}}$ GNSSinertial tools user guide, Rev. 4: Richmond Hill, Ontario, Canada, PUBS-MAN-001768, 523 p.

Brauer, E.J., 2009, The limitations of using specific-gage analysis to analyze the effect of navigation structures on flood heights in the Middle Mississippi River: Permanent International Association of Navigation Congress, 2009 De Paepe-Williams Award Contest, 18 p.

Calder, B.R., and Mayer, L.A., 2003, Automatic processing of high-rate, high-density multi-beam echosounder data: Geochemistry, Geophysics, Geosystems, v. 4, p. 1,048.

Environmental Systems Research Institute, 2010, ArcGIS, accessed September 2010 at http://www.esri.com/software/arcgis/

Hughes-Clarke, J.E., Mayer, L.A., and Wells, D.E., 1996, Shallow-water imaging multibeam sonars-A new tool for investigating seafloor processes in the coastal zone and on the continental shelf: Marine Geophysical Researches, v. 18, p. $607-629$.

Huizinga, R.J., 2009, Examination of direct discharge measurement data and historic daily data for selected gages on the Middle Mississippi River, 1861-2008: U.S. Geological Survey Scientific Investigations Report 2009-5232, 60 p.

Huizinga, R.J., Elliott, C.M., and Jacobson, R.B., 2010, Bathymetric and velocimetric survey and assessment of habitat for pallid sturgeon on the Mississippi River in the vicinity of the proposed Interstate 70 Bridge at St. Louis, Missouri: U.S. Geological Survey Scientific Investigations Report 2010-5017, 28 p. 
Huizinga, R.J., and Rydlund, P.H., Jr., 2004, Potential-scour assessments and estimates of scour depth using different techniques at selected bridge sites in Missouri: U.S. Geological Survey Scientific Investigations Report 2004-5213, 42 p.

HYPACK, Inc., 2009, HYPACK ${ }^{\circledR}$ Hydrographic survey software user's manual 1/09: Middletown, Conn., 1,394 p.

kcICON Project, 2010, Interstate 29/35 Connections Project Website, accessed July 26, 2010, at http://www.kcicon.org/.

Lagasse, P.F., Shall, J.D., Johnson, F., Richardson, E.V., Richardson, J.R., and Chang, F., 1991, Stream stability at highway structures: U.S. Federal Highway Administration Publication FHWA-IP-90-014 Hydraulic Engineering Circular No. 20, 195 p.

RESON, Inc., 2008, SeaBat ${ }^{\mathrm{TM}} 7125$ high-resolution multibeam echosounder system operator's manual, Version 6.01: Goleta, Calif., 100 p.

Richardson, E.V., and Davis, S.R., 2001, Evaluating scour at bridges (4th ed.): U.S. Federal Highway Administration Publication FHWA-NHI-01-001 Hydraulic Engineering Circular No. 18, 378 p.

Rydlund, P.H., Jr., 2009, Real-time river channel-bed monitoring at the Chariton and Mississippi Rivers in Missouri, 2007-09: U.S. Geological Survey Scientific Investigations Report 2009-5254, 27 p.
U.S. Army Corps of Engineers, 2004a, Upper Mississippi River System flow frequency study, Appendix E: U.S. Army Corps of Engineers, Rock Island, Illinois, accessed September 2010 at http://www.mvr.usace.army.mil/pdw/pdf/flowfrequency/ Documents/FinalReport/default.asp.

U.S. Army Corps of Engineers, 2004b, Engineering and design - Hydrographic surveying: Washington D.C., U.S. Army Corps of Engineers, manual no. EM 1110-2-1003, $560 \mathrm{p}$.

U.S. Geological Survey, 2003, User's manual for the National Water Information System of the U.S. Geological Survey: Automated Data Processing System (ADAPS): U.S. Geological Survey Open-File Report 2003-123, 413 p., accessed September 2010 at http://pubs.usgs.gov/of/2003/ofr03123/.

U.S. Geological Survey, 2010, National Water Information System: U.S. Geological Survey database, accessed March 2010 at http://waterdata.usgs.gov/nwis/.

Wilson, G.L., and Richards, J.M., 2006, Procedural documentation and accuracy assessment of bathymetric maps and area/capacity tables for small reservoirs: U.S. Geological Survey Scientific Investigations Report 2006-5208, 24 p. plus oversize figs.
Publishing support provided by: Rolla Publishing Service Center

For more information concerning this publication, contact: Director, USGS Missouri Water Science Center 1400 Independence Road

Rolla, MO 65401

(573) 308-3667

Or visit the Missouri Water Science Center Web site at: http://mo.water.usgs.gov 

Back cover. Point cloud visualization of the channel bed and left side of the main channel pier of structure A1800 on Interstate 635 over the Missouri River in Kansas City, Missouri. 


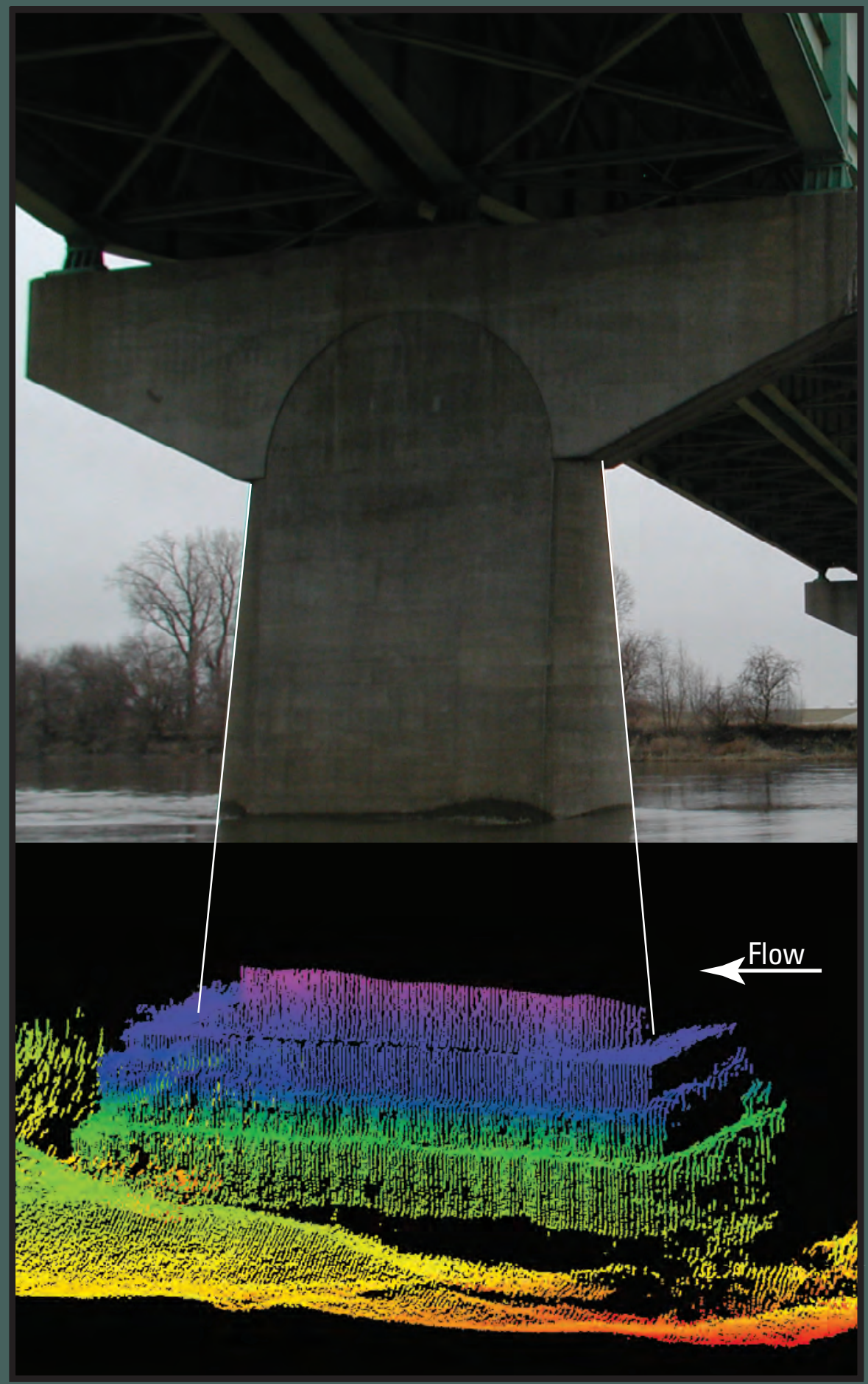

